DOI: $10.22455 / 978-5-9208-0610-9-167-284$

\title{
В. В. Мильков
}

\section{ТОЛКОВАЯ ПАЛЕЯ: ПРОБЛЕМЫ ИНТЕРПРЕТАЦИИ. НЕКОТОРЫЕ ИТОГИ ПОЧТИ ДВУХВЕКОВОГО ИЗУЧЕНИЯ ПАМЯТНИКА}

Аннотация: Автор анализирует историю почти двухсотлетнего изучения Толковой Палеи, представляющей жанр христианской экзегезы. В своей работе он рассматривает историю открытия памятника и суммирует результаты его текстологического исследования. В ней подробно характеризуются различные точки зрения на происхождение, датировку и историю бытования памятника. Много внимания уделено источникам Палеи и проблеме выбора составителем Палеи между представителями разных богословских школ. Особый раздел посвящен палейным апокрифам и выявлению смыслов, которые несут неканонические компоненты произведения. Делается вывод, что результаты междисциплинарного исследования Толковой Палеи лингвистами, филологами и философами являются основанием для правильной интерпретации сложного текста, его религиозно-философской специфики и палейной концепции космоустроения. Дается оценка вклада представителей разных научных дисциплин в реконструкцию антропологического и космологического комплексов Палеи. Показано влияние античных идей на трактовку человека как творения Божьего и на построение трехуровневой картины мироздания. Огромное количество списков Палеи оценивается как свидетельство распространения идей Толковой Палеи в общественном сознании Древней Руси.

Ключевые слова: Древняя Русь, Толковая Палея, текстология, история бытования, оригинальная концепция мироустройства, антропология, междисциплинарные исследования.

\section{V. Milkov}

\section{THE EXPLANATORY PALEIA: PROBLEMS OF INTERPRETATION. SOME RESULTS OF ALMOST TWO-CENTURIES STUDYING THE MONUMENT}

Abstract: The author analyzes a history of almost two-centuries studying the Explanatory Paleia, representing the genre of Christian exegesis. In the work he examines the history of the opening of the monument and summarizes the results of its textual research. Various points of view on origin, dating and histo- 
ry of Paleia's existing are in detail characterized in the work. Much attention is paid to Paleia's sources, the choice problem between representatives of different theological schools is considered in the article. The special section is devoted to apocryphal stories and identification of meanings of non-canonical components of the work. It is concluded that the results of the interdisciplinary study of the Explanatory Paleia by linguists, philologists and philosophers are the basis for the correct interpretation of the complex text, its religious and philosophical specifics, so as Paleia's concept of cosmostructure. The contribution of representatives of different scientific disciplines to the reconstruction of the anthropological and cosmological complex of the Paleia is evaluated. Influence of the antique ideas on the interpretation of man and the construction of a three-level picture of the universe is shown. A lot of Paleia's lists reflect the influence of its ideas on the public consciousness in Old Russia.

Keywords: Old Russia, Explanatory Paleia, textual criticism, the history of existence, original concept of world, anthropology, interdisciplinary studies.

Толковая Палея - это монументальное творение, заметно выделяющееся на фоне других произведений славяноязычной православной книжности. О принадлежности Толковой Палеи (далее - ТП) к конкретной национальной культуре в рамках Slavia Orthodoxa на протяжении многих и многих десятилетий ведется полемика ученых-славистов. С решением проблемы автора связаны и споры о датировке: сторонники болгарского происхождения текста удревняют ТП, а те, кто связывает Палею с Русью, датируют памятник домонгольской эпохой - золотой эпохой взлета и достижений раннехристианской отечественной письменности. Отсутствие прямых аналогов повествовательной форме произведения, его уникальные жанровые особенности, содержательная специфика и предназначение не получили в историографии принимаемого всеми объяснения. Более того, предлагавшиеся и предлагаемые интерпретации ТП вызывают едва ли не больший накал дискуссионности, чем проблема родины автора. Можно считать, что текст, его замысел и задачи, которые ставил перед собой создатель произведения, до конца не поняты исследователями. По крайней мере единства оценок ТП в историографии нет. До сих пор не прояснена и убедительно не обоснована история бытования текста и взаимоотношение его редакций.

Если рассматривать содержание произведения, то этот текст открывал перед его читателем грандиозную картину мироздания и погружал в обстановку начальной поры мировой истории, развора- 
чивавшейся в провиденциальную цепь библейских событий вплоть до царствования Соломона. Понятно, что значение каждого описанного действия, да и самих ветхозаветных персонажей в контексте экзегезы далеко выходит за пределы буквальных значений предметного описания. Задачи интерпретации подобных текстов усложняются тем, что цитируемые в ТП экзегеты относились к различным школам богословия и по целому ряду религиозных и мироведческих проблем давали разные трактовки. Как это учитывал и согласовывал составитель ТП, который в контекст строгого доктринального кредо включал значительные по объему заимствования из сочинений экзегетов разных направлений? Имели ли эти сведения для читателя самостоятельное информационное значение, отвечали ли они на интеллектуальные запросы древнерусских книжников и не затмевалось ли богатство фактуры задачами исключительно апологетики? Как соотносились между собой открывавшиеся перед читателями ТП познавательные горизонты и сугубо вероучительные, ориентировавшие на церковное назидание, части произведения? В кругу обсуждения и решения этих проблем и расходятся друг с другом сторонники разных интерпретаций. И только одно является для всех общепризнанным и понятным - Палея являет собой фундаментальную и обширную компиляцию, гениально задуманную и исполненную неизвестным нам автором, который «сшил» заимствования собственными полемическими связками и по сути дела создал оригинальный, ни на что не похожий труд.

В плотном и насыщенном событиями повествовательном потоке, в сюжетных узлах и авторских отступлениях раскрываются ноуменальные смыслы феноменального бытия. Решение этих задач невозможно без обращения к многовековой традиции экзегезы, что и демонстрировал составитель ТП, привлекая для создания своего труда обширный материал авторитетных церковных авторов и беспрецедентное для доктринального изложения количество апокрифических материалов. Мастерски осуществленная обработка мозаичных частей придает компиляции все признаки оригинального, с учетом специфики христианского сочинительства, творения. Этот по всем признакам необычный труд считают за честь отнести к своему национальному достоянию как болгары, так и русские. Сегодня эта проблема остается дискуссионной. Но не будем забегать вперед и обратимся к истории вопроса. 
Для образованных древнерусских книжников, а особенно для знатоков греческого языка, слово палея было знакомым и понятным, поскольку находилось в книжном употреблении. Этот оставленный в древнерусских рукописях без перевода греческий термин ( $\pi \alpha \lambda \alpha \iota \alpha)$ имел значение «ветхий». В общем смысле им обозначался Ветхий За-

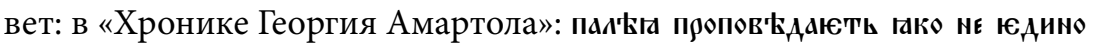
лице знанєноүють вйчьствит $(138$, с. 543); в Толковом Евангелии Фео-

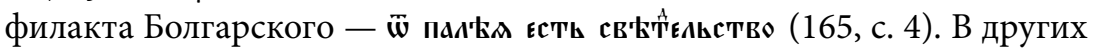
произведениях: и втортыи закон'ъ в палєи пишєт (62, с. 137); тако во сt сгадав" в пал'и (ГИМ. Син. № 210. Л. 76 в). Иногда термин применялся в более конкретном значении для обозначения Восьмикнижия и четырех библейских книг Царств. Такое словоупотребление читается в рукописи, которая содержит эти ветхозаветные книги: сїа книга гйемал пал'九 (РГБ. Григоровича № 1. Л. 373 а). Палеей также обозначали рукописи, которые содержат Пятикнижие: пал'а казєнағ. Встречалось в древнерусской книжности и словосочетание «палея с толком»:

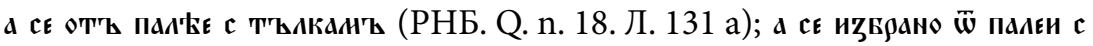
толкё (раздел в «Книге Кааф» - [158, с. 119]) и даже «толковая палея»:

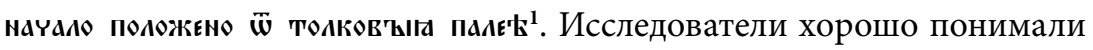
эту специфику и неоднократно подчеркивали, что «палеи с толком» процитированных сборников не имеют отношения к ТП, поскольку подобного рода отсылками в рукописных подборках обозначались комментарии Феодорита Киррского на Пятикнижие Моисея [160, с. $47 ; 158$, с. $135 ; 1$, с. 10$]^{2}$. По тонкому наблюдению В.М. Истрина, от обозначения существовавших прежде толкований Феодорита Киррского одноименное произведение отличалось уточняющим пояснением, обнаруживающим полемическое качество труда: «яже на иудея» [90, с. 73]. Разнообразные варианты употребления термина палея в славяно-русском книжном наследии рассмотрела Т. Славова и показала, что, несмотря на оттенки, словоупотребление было четко привязано к обозначению Ветхого Завета вообще или его разделов $[188$, c. $38-40]$.

1 Часть пространного надписания древнерусской «Книги Кааф» в части толкования Феодорита Киррского на Пятикнижие [158, с. 119; ср.: ••єядоритово т\ҚАкованиң пая'ћа - 194, стб. 869].

2 Пожалуй, только А.С. Архангельский склонен был связывать комментарии к ветхозаветным частям Библии из сборников типа Кааф с зависимостью от ПТ [10, c. 157-159]. 
Начиная с середины и до конца XIX столетия в составе средневековой отечественной книжности был выявлен целый ряд сочинений, в надписании которых значилось - «Палея». Как выяснилось впоследствии, под названием «Палея» фигурировали разные произведения и тексты разных палейных редакций. Однако первые их исследователи порой не проводили четкого разграничения между не схожими друг с другом Палеями, хотя и обращали внимание на отличия, что являлось предпосылкой дифференциации текстов по типам.

Начало введения Палеи в научный оборот было связано с отнесением палейного текста к разряду хронографов [197, с. 158]. Однако уже первые исследователи, обращавшиеся к рукописям с таким названием, начинали понимать, что они имеют дело с разными Палеями.

Первой из числа разнообразных Палей была вычленена Историческая Палея (далее - ИП), отличавшаяся значительными включениями апокрифического материала. Сначала А.Х. Востоков, описывавший рукописи Румянцевского музея, указал на отличие произведения с названиями «Очи палейные» от других палейных текстов, которые последующими исследователями были отнесены к типу Хронографической Палеи (далее - ХП). «Очи палейные» по списку Рум. № 359 (XVI в.) он считал сокращением Рум. № 297 (XVII в.), которую рассматривал как насыщенный хронографическими и апокрифическими сведениями текст. Обе рукописи он охарактеризовал как разновидности краткой Палеи $[54$, с. 420-422, 513]. Эту оценку, с незначительными поправками, позднее повторил И.Н. Жданов [75, с. 450]. Текст «Книги бытия небеси и земли» по рукописи ГИМ Син. № 591 (№ 318 по старой пагинации) А.В. Горский и К.И. Невоструев назвали Краткой Палеей [63, с. 593-597], а А.Н. Попов опубликовал его с разночтениями по Син. № 638 и № 548 [174, с. 1-48], связав происхождение ИП с Византией и датировав перевод концом XIV - началом XV вв. [174, c. XXXII-XXXIII; ср.: 38, с. 1-18]. К особому виду ИП был отнесен список РНБ Соф. № 1448, который был назван «сокращенной Палеей русской редакции» [174, c. XXXII-XXXIII]. Другие исследователи также усматривали в нем явные следы русской обработки Палеи [191, c. 17-20]. Позднее она была отнесена к Краткой Хронографической Палее (далее - КХП). И. Смирнов подробно описал «Книгу бытия небеси и земли» из Соф. № 1464 [191, с. 44-46]. И.Я. Порфирьев назвал 
РНБ Сол. № 866 (XVII в.) сокращенной редакцией Палеи и сблизил ее с Рум. № 297, при этом отметив признаки сокращения первоначального вида Палеи у первой [177, с. 16-17].

Еще в 1842 г. А.Х. Востоков выделил разновидность подробной Палеи (РГБ Рум. № 361 и 453) и противопоставил ее кратким Палеям (РГБ Рум. № 297 и 359). Эту разновидность он отнес к типу Палеи, который «слит с хронографом» [54, с. 517-518, 725-735]. Так впервые были обозначены признаки Хронографической Палеи (далее - ХП). Кажется, первым вопрос об особенностях собственно ТП заострил М. Сухомлинов, который обратил внимание на отличие ее от хронографов. Свои наблюдения он высказал в связи с тем, что включил Палею в число источников Нестора [198, с. 54-64].

Наблюдения Востокова и других предшественников развил И.Я. Порфирьев, который указывал на отличие Рум. № 361, 453 от Сол. № 653. Это отличие, по его мнению, выражалось в большей насыщенности апокрифами палейного текста с чертами хронографа [177, c. 11-12]. Весь массив палейных текстов он склонен был разделять на две группы: 1) в первоначальной Палее, назначение которой показать прообразный смысл ветхозаветных событий, наряду с устойчивой апокрифической триадой («Заветы двенадцати патриархов», «Откровение Авраама» и «Лествица») присутствовали незначительные апокрифические дополнения; 2) другая разновидность отличалась от первоначального состава обширными апокрифическими вставками [177, с. 11]. С одной стороны, он связывал первоначальный вид Палеи с преобладанием полемической акцентации, а с другой - считал краткий вид ХП (Сол. № 866) «согласным» с ИП (Рум. № 297) [177, c. 11-12, прим.]. Судя по всему, он не придавал слишком большого значения этим отличиям, рассматривая в одном ряду рукописи разных редакций (Тр. № 38, Рум. № 453, Сол. № 653 и т. д.). В своей подборке Порфирьев публикует смесь из разных типов палейного повествования, перетасовывая извлечения из Палей нескольких редакций и сборников с палейными вставками [177, с. 81-268]. В собственных исследованиях он ссылается то на тексты Сол. № 866, то на Сол. № 653, а также на публикацию апокрифических текстов Н.С. Тихонравовым [176, с. 34 и след.].

Еще с большей неразборчивостью к отличиям разных палейных текстов встречаемся в первом детальном исследовании ТП. В свод- 
ный список источников посвященного Палее монографического исследования В. Успенский помещает все известные к тому времени по литературе рукописи, фигурировавшие с надписанием «Палея». В его перечень, наряду с ИП, попали практически все разновидности ТП. Он перечисляет списки основных групп памятника, не выделяя их признаков, а сводя различия к разным объемам вставок в полемическое ядро. Основой Палеи без толкований он считает «Книгу бытия небеси и земли», излагавшей ветхозаветную историю с апокрифическими дополнениями. Признавая, что в ней апокрифы имеют иной характер, чем в ТП, он тем не менее сближает краткие версии ТП и ИП [209, с. 6-10]. Успенский оперировал исключительно тем же материалом, что и И.Я. Порфирьев, ограничиваясь в своем исследовании ссылками на рукописи РНБ Сол. № 653, 654 и 866. В результате информация из КХП чересполосно использовалась с извлечениями из ТП, которая по классификации Н.С. Тихонравова относилась к промежуточному между толковым и пространным хронографическим типом.

Четкого понимания типовых особенностей палейных текстов, как можно видеть, на ранней стадии введения ТП в научный оборот не существовало.

Первым осознал необходимость разграничения палейных редакций Н.С. Тихонравов, основывавший свои наблюдения прежде всего на апокрифических материалах ${ }^{3}$. Этот выдающийся знаток древнерусской книжности и апокрифических произведений первым предложил реконструкцию исторического развития видов Палей, которые он называл редакциями. Занимаясь исследованием апокрифов,

3 Разграничению разных палейных типов предшествовала работа по поиску и публикации апокрифических сочинений, значительное количество которых содержалось в ХП, что наглядно демонстрируют извлечения внеканонических текстов из сборников этой редакции $[166$, с. 9-10, 20-21, 24-49, 51-58; 203, с. 17-18, 24-25, 254]. По вопросу происхождения памятника исследователь высказывал противоречивые суждения. То он заявлял, что ТП составлена «славянином по материалам греческим и славянским» [204 дополнения, с. 110], то «под следами долгого пребывания на Руси» усматривал «черты древнеславянского языка, на который первоначально была переведена Толковая Палея» [204, с. 111]. В другом случае высказывался в пользу русского перевода и к древнейшей русской редакции относил мелкие переделки русского редактора, воспроизводившего Палею «в наиболее близком виде к греческому памятнику, который несомненно служил ей оригиналом» [204, с. 114]. 
Тихонравов отмечал расхождения между неканоническими сюжетами из разных палейных текстов. Как знатоку рукописей и пытливому исследователю апокрифов, ему были видны недостатки публикаций апокрифических сочинений предшественниками. В частности, А.Н. Пыпина он критиковал за недифференцированный подход к извлечению апокрифов для издания из разных палейных источников [183, c. 415-427].

В общем виде схема Н.С. Тихонравова сводится к следующему: 1) древнейший вид ТП представляют Коломенская 1406 г. (РГБ Тр. № 38) и датируемая им серединой XIV столетия Александро-Невская (РНБ СПбДА. А. І. 119) Палеи. Они, за исключением «Заветов двенадцати патриархов» и «Лествицы», не содержат в своем чтении целых апокрифов, поэтому историю Авраама, Иосифа и Моисея излагают кратко. Незначительные апокрифические включения, по словам исследователя, присутствуют здесь «урывками» [204 дополнения, с. 116-117]. Отличие Коломенской Палеи от Александро-Невского сборника он видел в ссылке на книгу «Иаковлевичи», которая отсутствовала в списке СПбДА. А. І. 119. Эту рукопись он сближал с ГИМ. Увар. № 85, поскольку в обоих списках к концу палейного повествования было присоединено «Откровение Авраама» ${ }^{4}$. Отмечалось и отсутствие полной тождественности между рукописями. Список Уваровского собрания

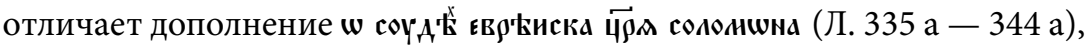
а само повествование доведено до царства Еровоамова. Эту особенность исследователь оценивал как «шаг к дополнению первоначального состава» [204 дополнения, с. 121]; 2) более позднюю - в авторском определении «среднюю» - редакцию Тихонравов связывал со списками первой половины - середины XV в., которые в сравнении с составом древнейшего вида Палеи имеют «Откровение Авраама», присоединенное к истории Авраама, и дополнительные апокрифические сведения об Адаме, Сифе и Мельхиседеке (Волок. № 549, Унд. № 7185); 3) младшая редакция рассматривалась исследователем как трансфор-

4 Входило в состав т. н. Сильвестровского сборника, который является частью разделенной рукописи, попавшей в РГАДА. Приводятся аргументы на этот счет со ссылкой на И.И. Срезневского (подробнее об этом см. ниже).

5 К среднему типу Унд. № 718 отнесена Тихонравовым ошибочно. Заявленный тезис о том, что она имеет в своем составе «Откровение Авраама» и является аналогом Волок. № 549 не подтверждается. 
мация полемического повествования в хронографическое. Ее типологическими признаками, по мнению исследователя, было включение в повествование апокрифических сюжетов о Моисее, Аврааме, царе Соломоне, о Китоврасе, пленении Иерусалима, хождении Сифа в рай, а также расширенное воспроизведение «Заветов двенадцати патриархов» (к данной редакции им относились такие рукописи, как Син. № 210, Син. № 211, Рум. № 453, Унд. № 719, которые датируются концом XV в.). По-видимому, Н.С. Тихонравов склонялся к мнению о том, что средняя редакция находится в более тесном родстве с младшей редакцией, поскольку они имеют общие чтения («Откровение Авраама»), отсутствующие в основном содержании древнейшей редакции. Старшую редакцию, по причине скудности неканонических элементов в ней, исследователь даже не склонен был назвать апокрифической. Явной апокрифической окраской, по его мнению, отличались две позднейшие редакции, этими признаками отличавшиеся от первоначального ядра ТП [204 дополнения, с. 114-115; 121-122]. Первоначальный вид ТП он считал «полемическим сочинением, наполненным против жидов», цель которого показать превосходство Нового Завета над Ветхим, для чего содержание ветхозаветной истории подавалось как «служебный символ Нового Завета» [204 дополнения, с. 157, 158].

Н.С. Тихонравов первым обосновал в науке идею о том, что ТП неоднородна и имела свою длительную историю. Для него важно было показать, что ТП «примкнула» к хронографу достаточно поздно, «позабывши свою первоначальную задачу», т. е. превратившись из полемического сочинения в историческое. Древнейшая Палея «не дорожит исторической последовательностью рассказа», а «отделы ветхозаветной истории, не поддающиеся символизации, она проходит молчанием» [202, с. 54]. Лишь только после «наращивания» исторической информации она «слилась» с хронографом. На эти существенные отличия типов палейного повествования Н.С. Тихонравов считал важным обратить внимание коллег. Свои соображения о разделении палейных списков на редакции исследователь высказывал еще в 1871 г. на II Археологическом съезде в Петербурге, что было зафиксировано в неопубликованном отчете от 9 декабря (см. об этом: [156, с. 9; 75, с. 452]).

Основные элементы выстроенной Н.С. Тихонравовым схемы получили развитие в трудах других исследователей. Прежде всего, в работах B.M. Истрина, который глубоко и детально изучал тексто- 
логические отличия палейных списков разных видов. К этому времени учениками Н.С. Тихонравова была опубликована Коломенская Палея с разночтениями по восьми спискам (164), а также начальная часть ХП - т. н. Псковская Палея по списку ГИМ Син. № $210[205]^{6}$.

B.M. Истрин в серии работ обосновал концепцию трех редакций Палеи. На протяжении нескольких десятилетий он специально самым детальным образом сопоставлял между собой текстовые отличия в пределах общих сюжетных конструкций разных Палей, а также в компаративном ключе оценивал композиционное построения материала, его объем и источники. В серии статей, которые впоследствии стали частями одной большой работы, были выявлены типологические признаки палейных повествований. На обширном эмпирическом материале установлен характерный для каждого из палейных типов текстовой состав и комплекс присущих каждой палейной разновидности признаков. Проведено их детальное сопоставление, по результатам которого выстроена концепция взаимоотношений редакций [84; 85; 89; 90]. Текстология для В.М. Истрина была частью комплексной работы по изучению содержания рукописей. Исследователь много внимания уделял взаимоотношениям палейных текстов с другими памятниками древнерусской литературы [88; 93; 94].

С древнейшей редакцией, вслед за Н.С. Тихонравовым, Истрин связывал группу списков, примыкающих к Коломенской Палее 1406 г. Это те списки, которые использовались для разночтений при публикации Коломенской Палеи: Александро-Невский, Кирилло-Белозерский, Силинский и Якушкинский списки [83, с. 436]. Исследователь пришел к выводу, что первоначальная редакция имела тот объем, который отражают опубликованные списки Коломенской группы. Истрин полагал, что у составителя ТП был замысел продолжить работу, но следов продолжения работы в полемическом ключе не обнаружено [87, с. 195; 83, с. 435-436]. Главной отличительной особенностью первой редакции, охватывающей события от сотворения мира до Соломона, было, по мнению исследователя, наличие антииудейских обли-

6 Отнесение издателями рукописи Син. № 210 к разряду Толковой Палеи не соответствует видовым признакам текста, впрочем, как и усвоение названия ТП другим спискам хронографической редакции, на что обращал внимание В.М. Истрин [87, с. 74-75]. 
чительных толкований. Исследователь высказывался и в том смысле, что ПТ, с ее полемической заостренностью, имела в славяно-русской книжности некий прототип, своего рода протопалею. Но речь шла не о ранних протографах ТП, на существовании которых настаивали в последующем некоторые ученые, удревнявшие историю памятника. Истрин ставил вопрос о жанровых аналогах и определенное родство антииудейским толкованиям в Палее он усматривал в комментариях Феодорита Киррского на Пятикнижие из «Изборника XIII века» по рукописи РНБ Q. n. 1.18.

Основания для выделения «средней редакции», в отличие от Тихонравова, В.М. Истрин не видел. Он исходил из того, что указанные Н.С. Тихонравовым особенности среднего вида имеют незначительные отличия от состава списков первой редакции, и считал их простым ответвлением от древнейшего вида ТП. Он признавал, что от группирующихся вокруг Коломенской Палеи текстов отличаются несколько близких друг другу палейных списков: Сол. № 653, Волк. № 549, Вяз. № 190. По его убеждению, пополнение их содержания «Откровением Авраама» и несколькими более мелкими апокрифическими сюжетами, дополняющими первооснову, не дают основания считать эту разновидность особой редакцией. Логика суждений такова: «Откровение Авраама» уже входило в некоторые списки первой редакции, а во второй оно лишь послужило для распространения истории Авраама. К тому же составитель Сол. № 653 привлекал во время работы дополнительно полный список одноименного апокрифа [87, с. 72, 73-74].

Истрин критикует Тихонравова за то, что тот оперирует понятием краткой и полной версии «Заветов двенадцати патриархов». И он прав в том, что полная редакция апокрифа не связана с Палеями, которые всего лишь воспроизводят краткую или более пространную переделки «Заветов» [87, с. 72-73; 91, с. 154-157]. Как видим, В.М. Истрин однозначно ставит списки ответвления («средней редакции», по Тихонравову) в родственные отношения с первой и древнейшей, по его классификации, редакцией, тогда как Тихонравов те же списки сближал с младшей хронографической редакцией. Последняя, в схеме Истрина, названа Полной редакцией Палеи, или Полной Хронографической Палеей (далее - ПХП).

Вторая редакция, по заключению В.М. Истрина, отличается от первоначальной некоторым сокращением толковательной части, рас- 
ширением охвата событий вплоть до христианской истории и значительным пополнением состава за счет включения в текст объемных апокрифических повествований и хронографических сведений. ТП входит в качестве составной части в эту редакцию7, хотя больший массив информации относится на счет воспроизведения хронографических данных и апокрифических материалов. Ко второй редакции Истрин относит следующие списки: РГБ Рум. № 453 (1494 г.), РГБ Унд. № 719 (у автора фигурирует как Рум.), ГИМ Чуд. № 348 (XVI в.), РНБ Пог. № 1435 (XVI в.), ГИМ Син. № 210 (1477 г.) [91, с. 139, 140].

В качестве источников, по наблюдениям Истрина, автором второй редакции использовались библейские книги, апокрифические тексты, «Хронограф по великому изложению» (отразившийся в «Архивском хронографе» и служивший транслятором сведений из «Хроники Георгия Амартола»), а также какая-то хронографическая компиляция, из которой заимствовались данные «Хроники Иоанна Малалы» и некоторые другие сюжеты [91, с. 168-203; 87, с. 196; 95, с. 52-61]. Наряду с текстом ТП, который был близок Кирилло-Белозерскому списку, и извлечениями из хронографов во вторую редакцию вносились: история Иосифа в изложении Ефрема Сирина и особый рассказ о Моисее, заимствованный из «Невротовой повести» [83, с. 419]. В библейской части апокрифические фрагменты первой редакции восстанавливаются до полного вида, к ним присоединяются отсутствовавшие прежде блоки неканонических повествований. Дальнейшее расширение повествовательной основы осуществляется за счет других дополнений. Например, история Моисея складывается из текста Коломенского типа, библейских дополнений и апокрифического Жития Моисея [91, с. 157-161; 90, с. 11-27], а история Соломона компоновалась на основании объединения сюжета из ТП, библейских фрагментов, апокрифических Судов Соломона и неопознанного источника [91, c. 164-168]. Кроме упоминавшегося уже «Откровения Авраама», апокрифических историй Моисея, Соломона и «Заветов двенадцати патриархов» во вторую редакцию были включены, по заключению Истрина, следующие апокрифы: «Мельхиседек», «Афанасия о Мельхиседеке», «Загадка к Лоту», «Смерть Авраама», «Лествица Иакова»,

7 Начало Палеи второй редакции сохраняет чтения Коломенского списка [91, c. $141 ; 87$, c. 75 ]. 
«Иаков и Исав», «Давид и Нафан», «Откровение Мефодия Патарского» $[83$, с. 419].

По сути дела, вторая редакция фиксирует трансформацию толкового повествования в историческое, в результате чего ТП приобретает сходство с хронографом и вполне претендует на то, чтобы считаться историческим сочинением [83, с. 435]. По наблюдениям Истрина, наименьшим изменениям, по сравнению с первой (древнейшей) редакцией, подвергся шестодневный раздел памятника, повествующий о творении мира. За счет хронографических пополнений раздвигаются временные рамки событий, ограниченные в начальном изводе ветхозаветной эпохой царей. По причине трансформации палейного ядра в хронографическое повествование B.М. Истрин даже был не склонен называть вторую редакцию «Толковой Палеей» в собственном смысле, поскольку «это есть исторический сборник и первоначальная редакция Толковой Палеи была лишь одним из многих источников сборника» [87, с. 195]. Несмотря на кардинальное изменение жанрово-тематической природы списков второй редакции, В.М. Истрин считает необходимым оставить за ней название «Толковой Палеи», поскольку так она надписывалась в рукописях $[87$, с. 74-75].

Сопоставляя ТП и ХП, В.М. Истрин указывал на отличия в манере работы с материалом авторами обеих редакций: если создатель первой редакции прибегал к переработке своих источников, то второй был буквалистом и тщательно воспроизводил привлекавшиеся им для работы тексты. По этому признаку списки легко отличать по их принадлежности к редакциям [87, с. 195; 83, с. 436]. В.М. Истрин предупреждал, что списки Полной редакции «не являются безусловно тождественными между собой». Эталонным является Погодинский список и близкий ему Соловецкий, которые дают сокращенную историю Авраама и имеют некоторые дополнения [83, с. 428].

Ученый не находил оснований для того, чтобы усматривать какую-либо связь между появлением второй редакции и ересью жидовствующих. Хотя по времени распространение списков ХП совпадало с подъемом еретического движения, характерный для толковой версии интерес к полемике с иудеями в них угас, а интенсивно пополнявшийся талмудическими рассказами текст имел признаки обычного библейского рассказа [87, с. 71, 198; 83, с. 423-425, 440]. 
Третью редакцию, по заключению В.М. Истрина, представляет Краткая Хронографическая Палея (далее - КХП). К ее признакам исследователь относит резкое сокращение текста в сравнении с содержанием полной, или ХП (наиболее характерными списками этой редакции он называл Погод. № 1434, Сол. № 866). Истрин специально подчеркивает, что третья редакция образовалась независимо от второй и в генетическом отношении с ней не находится. Их близость обусловлена общими источниками: «Третья редакция Палеи не может считаться сокращением какой-либо более древней редакции Палеи; она дошла до нас в том виде, в каком была составлена. Ее краткий вид объясняется тем, что, с одной стороны, автор ее сам сокращал свои главные источники - в первой части первоначальную Палею, во второй - “Хронограф по великому изложению”; а с другой - автор второй редакции распространял свои источник во второй части (библейские книги и “Хронограф по великому изложению”).

Благодаря пользованию авторами второй и третьей (полной и краткой) редакций Палеи одними источниками (Палея в первоначальной редакции и “Хронограф по великому изложению”) получается кажущаяся связь их в генетическом отношении, но непосредственного соприкосновения между ними не было» [83, с. 438].

В результате сокращения своих первоисточников, когда из них, прежде всего, воспроизводились исторические места, Палея в третьей редакции окончательно приобрела характер чисто исторического сочинения, близкого хронографу. Родство второй и третьей редакций, по наблюдениям В.М. Истрина, проявляется в хронографической части памятника, где фиксируется наибольшее число совпадений. Первоначальная редакция здесь отражается настолько, насколько она использовалась книжником, который сокращал исходный текст, при этом толковательные пассажи целенаправленно исключались и от них в новом тексте оставались лишь случайные и ничтожные следы. В результате в КХП оставалась исключительно историческая канва, и поэтому «памятник не может быть назван просто Палеей, так как последним именем назывались только библейские книги $<\ldots>$, если же мы называем его Палеей, то, конечно, условно» [83, с. 433].

Хронографическое повествование создатель третьей редакции, согласно наблюдениям Истрина, не только сокращал, но добавлял сведения из дополнительных источников (например, история Соломона, 
которая против ПХП включает заимствования из «Хроники Георгия Амартола» и еще какой-то хроники типа греческой Парижской 1336 г.) [90, с. 42]. В результате сокращения от описания некоторых исторических периодов оставалась минимальная информация (например, эпоха ветхозаветных царств представлена на уровне перечисления) [83, с. 438]. Историческую специфику третьей редакции Палеи Истрин даже склонен был толковать в духе оценок данного палейного типа современными исследователями и в заключении своих изысканий констатировал: «В собственном смысле и эта редакция должна была называться не Палеей, но историческим сборником; Толковая Палея была здесь лишь одним из источников» [87, с. 196].

Как можно видеть, основные признаки второй редакция, по B.М. Истрину, соответствуют Хронографической редакции по классификации Н.С. Тихонравова (к ней обоими исследователями относились Син. № 210, Рум. № 453, Пог. № 1435, Унд. № 719 и ряд других). Структурные элементы схем, которые были предложены двумя знатоками древнерусской книжности, в основных позициях совпадают. Сам Истрин считал, что Тихонравов верно наметил в своей концепции развитие палейных типов и в общем виде основные положения его концепции не утрачивают силы, а правки требуют лишь те идеи, которые не выдержали проверки с накоплением нового материала [91, с. 135-138]. На самом деле принципиальные отличия есть. Истрин расширил количество звеньев в схеме своего предшественника при одновременном сокращении промежуточного звена между первой и второй редакциями. Новаторство В.М. Истрина сводится к расширению семьи палейных текстов за счет принципиально нового компонента - КХП.

Наряду с построениями Н.С. Тихонравова и В.М. Истрина, которые базировались на классификации реально сохранившихся списков разных типов, предлагались концепции с реконструкцией возможных звеньев в предшествующей истории текста. В историографии появление гипотетических схем знаменовало новые подходы к изучению литературной истории Палеи.

Главным оппонентом В.М. Истрина выступил А.А. Шахматов. Шахматов выстраивал свою схему на допущении существования недошедших до нас источников, облик которых им и реконструировался. При этом исследователь исходил из убеждения в существовании 
сразу двух возможных прототипов известным науке палейным спискам. Эта схема с двумя неизвестными, надо признать, не получила широкой поддержки в среде отечественных исследователей. Конструкция выглядит слишком условной, чтобы ее можно было проверить реальными текстами. Тем не менее она, безусловно, повлияла на воссоздание литературной истории ТП, и в первую очередь болгарскими учеными.

И сходным пунктом концепции А.А. Шахматова являлось твердое убеждение в болгарском происхождении Палеи. Он относил ее к числу книг, попавших на Русь вскоре после принятия христианства. При этом ни один из сохранившихся рукописных изводов Палеи не признавался исследователем за первоначальный вид памятника. Известные русские списки возводились им к несохранившимся болгарским прототипам. По мнению маститого текстолога, уже в Болгарии сложились две редакции Палеи, одна из которых принадлежит перу Мефодия и отражает прения, которые вел его брат Кирилл с иудеями и сарацинами. Следы этой редакции, согласно исследователю, отразились в древнерусском тексте ТП в виде заимствований из Пространного «Жития Кирилла». Вторая редакция, которая названа А.А. Шахматовым «болгарской хронографической Палеей», отличалась, по его мнению, от первой вставками из Библии и апокрифическими дополнениями [215, с. 17-20]. Исследователь полагал, что первоначальная болгарская редакция лучше всего отразилась в Коломенской Палее, но одновременно присутствует влияние и хронографической редакции (статья о расселении языков). Затем на основе хронографической болгарской редакции на Руси появились две кратких русских редакции: третья (по классификации Шахматова) отразила влияние Слова Мефодия Патарского, а четвертая редакция - влияние ИП $[215$, с. 20-21, 73]. В своей критике Истрина Шахматов указывал на то, что третья редакция (т. е. КХП) местами значительно полнее второй, а это дает основание предполагать существование некоего общего источника (или источников), к которым могут независимо друг от друга восходить палейные редакции.

Взаимоотношения Палеи и летописи реконструируется русским текстологом следующим образом: уже в Болгарии из толковой и хронографической редакций были сделаны краткие извлечения, скомпонованные в виде речи Кирилла Философа. Последняя, как изло- 
жение кратких истин христианской веры, была включена в рассказ о крещении князя Бориса. Затем эти компилятивные выдержки в XI в. были в готовом виде включены в древнерусскую летопись, в составе которой они соответствуют «Речи философа» [215, с. 73]. В обоснование данного вывода исследователь приводит параллельные чтения в летописи и Коломенской Палее, а также ссылки на аналоги «Речи философа» во внелетописных статьях. Последние, совпадая содержательно с «Повестью временных лет», имеют указания на связь с Палеей («Слово о бытии всего мира» в переделке Пог. № 1560 озаглавлено «Слово о сотворении неба от палеи»; внелетописная редакция «Речи философа» по сборнику МДА № 364 надписано «Слово из палеи выведено на жиды») [215, с. 25-27]. В доказательной части учитываются как разночтения, так и параллели между двумя памятниками, но перевешивают аргументы в пользу однородности «Речи философа» составу ТП. В итоге исследователь делает вывод, «что Речь философа представляет из себя краткое извлечение из Толковой палеи» [215, с. 51]. Кроме того, высказывается допущение, что при составлении начального свода в XI в. использовались сведения болгарской Хронографической Палеи [215, с. 73].

Коломенский тип А.А. Шахматов рассматривает как первую русскую переработку несохранившегося болгарского протографа, образованного из соединения элементов Толковой и Хронографической болгарских редакций Палеи. Чтобы объяснить характер русских дополнений, делается допущение, будто болгарский протограф ТП подвергся на Руси коренной переработке [215, с. 74]. Вторая русская переработка, отождествляемая А.А. Шахматовым с Синодальным типом (ХП по В.М. Истрину), возводится к пополнению Коломенского извода из болгарской Хронографической редакции [215, с. 21]. Как уже упоминалось, исследователь выделял третью краткую редакцию, выборочно соединявшую в себе особенности первых двух и четвертую (или «особую хронографическую») редакцию, которая, по определению автора, представляла собой «маленький Хронограф». Он считал, что эта редакция, представленная списком Син. № 323, давала весьма сжатое изложение истории, составленное из соединения фрагментов первоначальной болгарской Палеи и Хронографа [215, с. 15].

Контраргументы против выделения четвертой русской редакции привел В.М. Истрин, который показал, что это всего лишь обычная 
разновидность «краткой истории» и никакого хронографического вида Палеи в природе не существует [90, с. 435, № 3]. По его мнению, признаков редакции не наблюдается, а содержание рукописи представляет собой «не что иное, как любительские выписки из бывших под руками источников» [89, с. 160]. Кроме того, В.М. Истрин привел доводы против идеи А.А. Шахматова о существовании предшествующих русским переработкам болгарских редакций. Весомым представляется тот довод В.М. Истрина, что за вычетом очевидных вставок, выделяемых в древнейшей (по А.А. Шахматову) русской редакции, на долю изначального болгарского текста остается ничтожно малая часть и почти весь Коломенский извод, таким образом, предстает плодом творчества русского автора [89, с. 158].

Под влиянием критических возражений В.М. Истрина А.А. Шахматов внес некоторые изменения в базисные положения выстроенной им концепции и в своей последней работе посчитал возможным говорить о принципиально ином характере отношений между летописью и Палеей. Общие для «Повести временных лет» и ТП чтения он стал объяснять влиянием летописи, а совпадения с Хронографической (Полной) и Краткой Хронографической Палеями по-прежнему возводил к общему для этих Палей и летописи источнику [215, с. 79].

Практически в одно время с В.М. Истриным к разработке палейной тематики обратился А.В. Михайлов. С его именем связаны важные достижения русской палеистики, поэтому на характеристике его работ следует остановиться подробнее. Все начиналось с небольшой рецензии на вышедшие из печати исследования ТП, среди которых наибольшее внимание было уделено монографии В.М. Успенского [156, с. 1-21]. В жанре рецензии исследователь не только охарактеризовал тогдашнюю палеистику, но сумел обозначить круг самых важных проблем, на решении которых необходимо сосредоточится в дальнейшем изучении ТП. Охватывая сделанное до него, Михайлов сокрушался, «как мало еще подготовлена почва для решения основного вопроса о Палее, о месте и времени ее появления в литературе» [156, с. 19]. Для более глубокого понимания памятника, по его убеждению, необходимо изучение редакций соединить с фундаментальным анализом состава и литературных источников памятника.

В деле установления редакций Михайлов отмечает наличие определенных наработок. Он отдает должное вкладу Н.С. Тихонравова, 
разделившего палейные списки на три семьи. Указаны и слабые места в построениях Н.С. Тихонравова. Главным недостатком он считал то, что Тихонравов устанавливал палейные редакции только относительно апокрифов и слабо учитывал в своей классификации характер других составных частей палейного повествования. На фоне трудов Тихонравова, по его мнению, значительно проигрывают работы И.Я. Порфирьева и В.М. Успенского, которые игнорировали редакционные отличия. А изучение Палеи по немногим позднейшим и случайным источникам, как это делал Успенский, Михайлов считает вообще недопустимым, соответственно и научное качество труда этого русского палеиста он оценивает крайне невысоко $[156$, с. 9, 16].

Но если редакции в тогдашней историографии уже каким-то образом обозначились, то конкретные источники палейной компиляции, по заключению А.В. Михайлова, не были определены в рецензируемых работах. Многослойностью состава ТП он объяснял отсутствие ясности в этом вопросе. Демонстрируя глубокую научную проницательность, решение важной для понимания памятника проблемы А.В. Михайлов связывал с разложением ТП на составные ее части для последующего сопоставления их как с греческими прототипами палейных фрагментов, так и с переводами соответствующих сочинений в составе древнерусской книжности. Исследователь исходил из того, что, осуществляя сравнение выявленных составных частей с известными славянскими или древнерусскими переводами, можно установить первоисточники, которые находились в распоряжении составителя ТП. Именно с этих позиций Михайлов критикует B.M. Успенского, который, не решившись разложить ТП на составные части, все узнанные им в содержании Палеи тексты (а их более 30) отнес на счет прямых заимствований. В результате столь упрощенного подхода к многосложной конструкции палейного повествования в первой монографии о ТП круг действительных источников этого компилятивного сочинения так и не был определен. Подобного рода неразборчивость помешала Успенскому отделить авторский текст от заимствований, а без этого специфика палейного построения закрыта для понимания.

По твердому убеждению А.В. Михайлова, работа с содержанием ТП невозможна без учета того, что за всем стоит рука автора: «Толковая Палея - не просто компиляция бессвязных и сшитых на живую 
нитку выписок, а настоящее сочинение, где чужое искусно переплетается со своим, где видна определенная и ясная мысль, которая проходит от начала до конца» $[156$, с. 2]. Критик первой когорты русских палеистов считал, что необходимо строго отделить то, что в тексте принадлежит автору-составителю и что является заимствованием. На этом пути, предупреждал он, много подводных камней, поскольку не всякий отрывок библейского или какого-либо иного текста мог быть внесен лично составителем. Поэтому он крайне негативно относился к тем авторам, которые видели в Палее сплошную компиляцию и на долю составителя ничего не оставляли. Михайлов абсолютно новаторски для своего времени и, главное, абсолютно адекватно историческим реалиям исходил из того, что многие из фрагментов попадали в текст ТП из вторых рук вместе с заимствованием больших кусков компилятивных по своему происхождению источников: «В Палее следует отличать источники самого автора, от источников разных сводных статей, целиком или частью занесенных в Палею» $[156, \text { с. } 13]^{8}$.

Естественно, вставал вопрос: как отделить мелкие заимствования от включений в содержание целых компилятивных блоков. Кроме чисто текстологических приемов, исследователь предлагает не гнушаться особенностями внешнего вида текста, когда в списках инициалами и особыми значками отделялись одни блоки от других 9 .

Михайлов был едва ли не первым палеистом, кто осознал необходимость комплексного подхода к изучению сложнейшего по составу памятника. Процедура анализа представлялась ему связанной с реконструкцией первоначального вида ТП путем освобождения от позднейших наслоений. Он выражал убежденность, что в деле восстановления первоосновы ТП точное знание источников позволит составить четкое представление о том, как складывалось богатое и разнообразное содержание ТП. Это, по его пониманию, можно сде-

8 Некоторые из современных исследователей игнорируют эту очевидную истину, что уводит их от правильного понимания памятника (об этом см. ниже, в связи с разбором концепции Т. Славовой).

9 При всей спорности такой методы, нельзя не признать, что рациональное зерно в ней есть, только единственный опыт применения такого подхода к источникам на практике предпринял К.К. Истомин, и опыт этот оказался крайне неудачным (подробнее см. ниже). 
лать только путем сличения палейных списков между собою и средствами фиксации отличий со стороны состава. Игнорирование редакционных отличий и вариативности в архитектуре построения разных палейных текстов, столь характерное для коллег-предшественников, не способствует адекватной характеристике памятника. И в этом исследователь был, безусловно, прав.

В кругу проблем, относящихся к палеистике, не меньшее значение отводилось А.В. Михайловым задаче установления родины создания ТП. Он самым решительным образом выступил против скоропалительных и не подкрепленных доказательствами мнений о происхождении текста. В рецензии обращалось внимание на то, что «всех ослепляла гипотеза о греческом происхождении памятника» [156, c. 8]. У своих предшественников он не обнаруживал убедительного решения проблемы, поэтому история появления ТП на тот момент во многом представлялась ему «загадочной». И все-таки конкретные аргументы для решения этой «загадки» уже подбирались.

Здесь надо отметить, что Михайлов весьма скептически отнесся к исследователям, которые полагали, будто на Руси отсутствовали литературные силы, способные создать столь выдающееся произведение. Естественно, что выводы авторов, которые уклонились от филологической критики источника и ничем не подкрепляли свой грекофильский подход к оценке ТП, не убеждали. Особенно несостоятельным и тенденциозным представлялось критику соотнесение палейных фрагментов из сочинений Козьмы Индикоплова, Иоанна Малалы, Георгия Амартола и т. д., исключительно с греческими первоисточниками. Ему были непонятны те авторы, которые считали вставки из «Шестоднева» Иоанна экзарха Болгарского позднейшими наслоениями. В его понимании таковые не могут быть позднейшими дополнениями уже потому, что органически слиты с общим содержанием палейного повествования, которое за вычетом этих «вставок» просто рассыпается. А.В. Михайлов вообще считал, что достаточно одного сопоставления фрагмента из сочинения Епифания Кипрского о двенадцати камнях с соответствующим местом из «Изборника 1073 года», чтобы подорвать уверенность в византийском происхождении ТП. Получается, что уже на уровне предварительных соображений исследователь склонялся к тому направлению в историографии, представители которого видели в ТП русское произведение. 
Многие из наблюдений А.В. Михайлова намного опередили свое время. Он, например, первым в палеистике посчитал возможным назвать ТП энциклопедией, которая насыщена самыми разнообразными сведениями. Соответственно и на автора-составителя Михайлов смотрел как на высокообразованного книжника, который оперировал в своем труде подлинной россыпью сокровищ разнообразных знаний. Не занимаясь специально сопоставлением списков толковой редакции, наш палеист проницательно увидел, что некоторые из рукописей Коломенской группы более исправны, чем выдававшаяся Н.С. Тихонравовым за первоначальный вид Тр. № 38. Только одно сопоставление опубликованных разночтений к ней привело Михайлова к выводу, что нет оснований считать Коломенский список удачно взятым за основу ответственной публикации. Такую оценку в последнее время еще раз подтвердил Е.Г. Водолазкин.

Можно сказать, что намеченные А.В. Михайловым аспекты исследования ТП в последующем оформились в отдельные направления палеистики, а на одном из таких направлений сам Михайлов был бесспорным первопроходцем. До него никто не обращал внимания на важность библейского текста, который является стержнем всего содержания ТП и в силу этого может рассматриваться как изначальная основа сюжетного построения произведения. Михайлов же не только указал на центральное место восьми ветхозаветных книг в архитектуре Палеи, но и первым произвел сравнение этого библейского ядра со славянскими переводами и древнерусскими списками ветхозаветных книг.

Но это будет уже в следующих работах, где заявивший о себе как о палеисте исследователь приступит к анализу конкретики. В первой же своей статье он только формулирует исходные принципы, которые затем и будет воплощать в собственных работах. Характерно, что именно в первой статье ставилась задача охватить сличением максимально крупные разделы памятника, а не ограничиваться только его избранными мелкими частями. Автор вполне отдавал себе отчет в том, что, имея дело с извлечениями из Писания в компиляцию, надо избежать опасности выдать за основной библейский текст библейские фрагменты из вставок. А для этого, как заранее определил исследователь, нужно реконструировать состав и источники ТП [156, c. 20-21]. Принцип комплексного подхода к анализу он в первую очередь применял к себе. 
В 1895-1896 гг. А.В. Михайлов осуществляет обстоятельный разбор бытийных компонентов из состава ТП и формулирует тот же вывод о происхождении Палеи, что и В.М. Истрин, который обосновывал свою точку зрения на основе анализа других источников. Средствами текстологического анализа Михайлов показывает, что при создании ТП использовалась русская редакция древнеславянского перевода бытийных разделов. С этой целью палейный текст Книги Бытия Михайлов сопоставляет с южнославянской паремийной версией и обнаруживает дополнения, которые совпадают с полной версией Книги Бытия по древнерусским спискам. Влиянием древнерусской редакции библейского текста объясняются отступления от южнославянского перевода. Возможное обращение составителя Палеи к греческому тексту отводится на том основании, что если бы он делал самостоятельный перевод, то этот перевод имел бы отличия от имеющихся переводов в древнерусских списках. Допустить, что составитель (он же переводчик) каждый раз обращался для правки к имевшемуся уже на руках переводу, невозможно. Остается считать, что использовались древнеславянские тексты, причем прошедшие обработку на Руси. Фактор русских особенностей при воспроизведении библейских текстов произведения давал А.В. Михайлову основание считать ТП древнерусским сочинением [154, с. 1-35; 155, с. 1-23].

В палейной историографии выводы А.В. Михайлова стали принципиально новой реальностью. Логично было ожидать, что исследователи ТП как-то отреагируют на свежие идеи. Но прошло несколько десятков лет после публикаций Михайлова, вышел из печати цикл работ В.М. Истрина о Толковой Палее, увидело свет обширное исследование А.А. Шахматова, посвященное проблеме взаимоотношений Палеи и летописи, свершилась революция и минули годы Гражданской войны, а труд Михайлова так и не был вовлечен в обсуждение палейной темы.

В конце 1920-х гг. А.В. Михайлов снова обратился к анализу литературных источников ТП, и формальным поводом для возобновления работ стала проверка гипотезы Шахматова о принадлежности первоначальной редакции ТП Мефодию или его ученикам. На самом деле вернуться к палейной тематике Михайлова побуждало не только желание высказать свои соображения о концепции А.А. Шахматова, в которой обосновывалось болгарское происхождение ТП. Исследователь не скрывал обиды и в прямой форме упрекал палеистов в 
игнорировании его наблюдений. Он искренне удивлялся, почему ни Шахматов, ни Истрин не приняли во внимание его доводов.

Судя по всему, причина лежала не в научной плоскости, а в характере личных взаимоотношений между исследователями. Попробуем прояснить суть дела. Упрек Истрину можно считать недоразумением. Последний принял и доводы, и вывод Михайлова [87, с. 36]. Правда, сделал он это как-то сквозь зубы. Дело в том, что Истрин ревниво относился к Михайлову и считал, что тот незаслуженно обходил его своим вниманием как палеиста, а общие критические высказывания по поводу пристрастия коллег к изучению мелких фрагментов в составе ТП принимал на свой счет [86, с. 176-177, прим.]. И по другим нюансам можно судить, что нормальных взаимоотношений между исследователями Палеи не существовало. Эта взаимная отчужденность авторов, придерживавшихся близких взглядов на происхождение ТП, представляется парадоксальной. Но, видимо, так бывает, когда на одном поле сходятся два крупных ученых, не желающих делить пальму первенства и выражать взаимное уважение.

Так или иначе А.В. Михайлов вновь возвращается к своей излюбленной теме и в очередной раз обращает внимание научной общественности на специфику взаимоотношения Палеи с библейскими ее первоисточниками, а конкретно с книгами Исход и Руфь, которые существовали в южнославянском и русском изводах.

А.В. Михайлов, со своей стороны, по достоинству оценил вклад B.М. Истрина в разработку первоисточников ТП, правда, не без оттенка уничижения называл его работы «рядом этюдов». Впрочем, выводы о русском происхождении и датировке Палеи он полностью разделял, а попытку пересмотра их А.А. Шахматовым считал неубедительной. В его понимании, Шахматов разошелся с верным мнением на Палею, поэтому нет оснований принимать его точку зрения, согласно которой Коломенская Палея является результатом «двойной переработки» древнеболгарского протографа. Чтобы доказать это, Михайлов дает роспись глав из книги Исход, вошедших в ТП, и обнаруживает большие сокращения даже против паремийного состава соответствующих ветхозаветных текстов. Кроме того, он обнаруживает влияние на ТП в этой части русских четьих списков, которые сохранились в рукописях XIV-XVI вв.

Извлечения в Палею из книги Руфь, которая никогда не входила в состав богослужебных текстов, исследователь сопоставляет с глаго- 
лическим и кириллическими списками этой книги и устанавливает черты сходства ветхозаветных чтений с южнославянским изводом. Михайлов показывает, что библейские тексты в Палее отличаются от перевода Мефодия, а попытки Шахматова объяснить эти расхождения неоднократной перепиской сначала в Болгарии, а потом на Руси считает необоснованными. Палейным чтениям из книги Руфь находятся соответствия в древнерусских списках XV-XVI вв. Отсюда вывод: составитель ТП не пользовался архаическими библейскими текстами. В его распоряжении был источник, в котором болгарский паремийный текст был соединен с болгарским же четьим. Эта контаминация, читающаяся в русских списках, могла появиться не ранее XIII в. Следовательно, гипотеза о болгарском происхождении ТП несостоятельна [221, s. 115-131; 153, с. 49-80].

Такова история появления еще одной оригинальной концепции на поле отечественной палеистики.

После трудов Н.С. Тихонравова, В.М. Истрина, А.А. Шахматова и А.В. Михайлова в дореволюционной науке были буквально единичные случаи обращения специалистов к палейной тематике. Пожалуй, самым обстоятельным исследованием была публикация В.П. Адриановой, которая имела литературоведческую специфику и во многом базировалась на обобщении уже достигнутых прежними исследователями результатов. Эта обширная по своему объему публикация состоит из двух частей: 1) подробной и разносторонней характеристики палейных текстов разных типов и всей проблематики, связанной с их интерпретацией [1, c. 1-39]; 2) детального палеографического и лингво-текстологического описания Академического списка ТП из собрания Киевской духовной академии Аа $1292\left[1\right.$, с. 40-63] ${ }^{10}$. Не будет преувеличением назвать первую часть труда работой компилятивного типа. Исследовательница оперирует в ней уже существующими наработками в палейной историографии, и ее собственный вклад относится только к комбинированию и изложению уже имеющихся наблюдений. Приводится полная на то время историография вопроса и делается обзор всех концептуальных трактовок непростого для понимания содержания ТП. Вслед за

10 В дополнении публикуются антииудейские пророчества по списку Михайловского монастыря № 493/1655 1483 г. с кратким анализом текста и его содержания в сравнении с аналогичной полемической заостренностью Палеи [1, с. 64-77]. 
Истриным она группирует дифференцированные текстологом списки по трем редакциям и с обозначением шифров хранения формализует уже известную схему взаимоотношения текстов. В деталях рассматривается апокрифический репертуар, который отличает одну редакцию от другой. И опять-таки это делается на основе переработки уже имевшихся в литературе данных на этот счет.

Сама Адрианова в вопросе о редакциях, времени и месте появления ТП солидаризируется с концепцией Истрина-Михайлова и самым подробным образом суммирует все высказывавшиеся ими аргументы. Что касается роли каждого из этих исследователей в обосновании концепции автохтонного происхождения ТП, то пальму первенства она отдает А.В. Михайлову и считает, что тот первым обосновал русское происхождение ТП. Она показывает, что Истрин приходит к тому же выводу, базируясь на других основаниях, и даже высказывается в том смысле, что Истрин следует за Михайловым в своих доказательствах русского происхождения автора ТП. Так или иначе труд В.П. Адриановой - это единственная работа в палеистике, которой свойственна прямая и акцентированная апология достижений и аргументов А.В. Михайлова. На страницах работы оба текстолога поставлены плечом к плечу. И это едва ли не намеренная компенсация того, что исследователи слишком очевидно в своих работах сторонились друг друга.

В общем и целом ТП в труде Адриановой характеризуется как компилятивный памятник, составленный на русской почве в XIII в. Далее читатель информируется, что в процессе бытования палейное содержание изменялось и на основе полемического коломенского типа появились еще две редакции: одна названа «исторической» по причине соединения с хронографом, а другая - сокращенной исторической, появившейся на основе общих источников, а не в результате сокращения второй редакции. Ни в этих, ни в других своих суждениях автор не привносит никаких новых оценок, кроме уже существовавших к тому времени. Поэтому и само исследование вряд ли можно назвать вполне самостоятельным. Точнее, его можно было бы назвать популяризацией взглядов Истрина-Михайлова. То отчуждение, которое существовало между двумя текстологами, на страницах ее труда с легкостью преодолевается. Фактически она «оформила» этот концептуальный союз, факт которого так тщательно не желали озвучивать ревнивые друг к другу единомышленники на поле палеистики. 
Вторая часть труда, в отличие от первой, наиболее интересна, нова и самостоятельна. В ней представлено подробное описание палейного списка, который ранее не был в поле зрения исследователей ${ }^{11}$. В орфографии отмечаются следы староболгаризмов. Проводится лингвистический анализ текста, который показывает сочетание западнорусских и южнорусских языковых особенностей. На этом основании создание списка локализуется в пределах Литовской Руси с влиянием юго-западной литературной традиции. Появление текста относится к 60-м гг. XVII столетия.

Проанализирован состав и содержание рукописи. Отмечено наличие дополнений в сравнении со списками Коломенского вида. В частности, указано на добавление из "Сказания Афродитиана», которое внесено в сюжет о Лествице. По мнению В.П. Адриановой, встретив в тексте отрывок этого апокрифа, писец старается познакомить читателей с его содержанием [1, с. 52-53]. Кроме дополнений в виде комментариев на полях и ссылок на источники, в тексте указываются места правок прежде ошибочных чтений и распространение усеченных цитат.

В.П. Адрианова относит список к I редакции по классификации Истрина, но при этом отмечает, что имеются значительные отличия от группы Коломенских списков. Это позволяет утверждать, что ни один из них не мог послужить в качестве оригинала для копирования. Делается вывод: отличительные признаки позволяют говорить об Аа 1292 как об особом ответвлении от Коломенской группы, появившимся на южнорусской почве. Судя по информативному качеству дополнений, рукопись находилась в обиходе у высокообразованных и широко подготовленных книжников.

Суммируя сказанное, прежде всего надо подчеркнуть важное значение второй части в общем замысле работы, благодаря которой в научный обиход вводятся детально прописанные характеристики нового списка ТП. С учетом этого и весь компилятивно-описательный контекст введения в палейную проблематику получает свое оправдание. Обе части можно рассматривать как пространное вве-

11 Сборник Киевской духовной академии Аа 1292 ныне имеет иной шифр по месту нового хранения: Библиотека НАН Украины им. В.И. Вернадского. Фонд: Мел. м. п. № 114. 
дение к возможной публикации памятника. Остается сожалеть, что непосредственно публикация текста украинской версии ТП еще не осуществлена.

В 1908 г. в «Известиях Отделения русского языка и словесности Императорской АН» вышла статья А.В. Рыстенко, который был учеником В.М. Истрина и интересы которого распространялись на сферу палейной проблематики. Автор вводит в оборот текст из рукописи Тр. № 39, озаглавленной «Стихи избранныя от книгы глаголемыя Палея». Он сравнивает этот текст с Коломенским списком Палеи и наряду с совпадениями отмечает значительные расхождения, главным из которых было отсутствие обличений жидовина. Текстовое сличение Tр. № 39 с аналогичным текстом в «Златой матице» дало основание считать первый источником второго [184, с. 324-334]. В свое время B.М. Истрин привел ряд соображений (с некоторыми гипотетическими допущениями), что «Златая матица» могла послужить источником для составления сюжетов о природе в ТП [86, с. 135]. Рыстенко не нашел подтверждения этой гипотезе и сделал вывод о том, что Тр. № 39 была построена на основе палейных материалов [184, с. 335]. Вместе с тем он не исключал, что автором подборки о природе мог быть сам составитель ТП, который хорошо знал эти материалы. Позднее ареал естественнонаучных компиляций сходных с Тр. № 39 и «Златой матицей» был расширен за счет обнаружения аналогичных материалов в других древнерусских сборниках [55, с. 183-197; 51, с. 80-90]. Если Н.К. Гаврюшин до проведения специального исследования не считает проблему взаимоотношения естественнонаучных подборок с ТП решенной, то Е.Г. Водолазкин поддержал мнение Рыстенко и сделал категоричный вывод, что ни один из аналогичных Тр. № 39 естественнонаучных текстов не может являться источником ТП. Взаимоотношение между ними обратное - энциклопедическое содержание Палеи давало материал для природоведческих статей в древнерусских сборниках [51; 89]. Начинание А.В. Рыстенко получило развитие, и остается только сожалеть, что обещанного им продолжения на тему палейного влияния в древнерусской книжности так и не последовало.

Как можно было видеть, А.В. Михайлов и В.П. Адрианова в своих построениях принимали концепцию Истрина. А.В. Рыстенко так же не покушался на слом схемы своего учителя и лишь корректировал отдельные частные наблюдения своего предшественника. Но появились 
в печати и выступления с позиций прямого неприятия взглядов и выводов Истрина, касающихся истории бытования Палеи и соотношения представляющих ее версий. Еще при жизни Истрина у него появился оппонент, который поставил вопрос о необходимости пересмотра сложившихся и воспринятых научным сообществом палейных редакций.

«Новаторски-революционную» концепцию взаимоотношения палейных редакций в пику уже существующим выдвинул в начале ХХ столетия К.К. Истомин. По собственному признанию автора, он руководствовался решительным намерением «высвободить Толковую Палею из-под спуда Тихонравовской теории», к приверженцам которой Истомин относил как В.М. Истрина, так и А.А. Шахматова. Если, по его мнению, первый практически принял классификацию Н.С. Тихонравова, то второй - также находился в русле разработанной предшественниками схемы, ибо все сходились во мнении, что КП в сравнении с ХП является более древним типом. К.К. Истомин отметает все выводы и заключения предшествующих ученых, предлагая радикальный пересмотр сформулированных до него взглядов на взаимоотношения палейных редакций.

В пику приверженцам прежней схемы К.К. Истомин объявляет древнейшим хронографический тип, который он возводит к несохранившемуся хронографическому протографу. Появление ХП датируется им концом XI - началом XII вв. и связывается с окружением князя Святополка, при котором обострились отношения киевского населения с ростовщиками. От этого несохранившегося первоначального варианта, по убеждению автора, пошли списки Син. № 210, Рум. № 453, а лишь затем появились толковые варианты. Причем картина истории развития палейных типов Истоминым усложняется. Он полагал, что на основе ХП был создан текст, который предшествовал ТП, и от него произошли как ТП, так и КП [82, с. 69-72]. Суть концептуальных расхождений Истомина с предшественниками сводилась к следующему: считать ли ПХП результатом дополнения ТП новыми источниками, как до этого думали, или происхождение ТП связывать с сокращением ПХП, как представлялось естественным создателю новой концепции. Путь к сокращению он считал наиболее логичным для истории памятника.

В своих рассуждениях К.К. Истомин отбрасывает применяемые в науке методы исследования текстов и ориентируется на указание ки- 
новарных разделительных знаков в тексте как на главный показатель компиляторских приемов древнерусских книжников, расшифровывая которые, по его глубокому убеждению, можно с точностью восстановить последовательность редакций. На отказе от строгих текстологических приемов рассмотрения текста и пренебрежительном отношении к достижениям предшественников построена «революционная» теория К.К. Истомина [79; 80; 81; 82].

Результат многолетнего исследования К.К. Истомина известен: в русской историографии предложенная им концепция так и не нашла последователей. Не исключено, что значительную роль сыграл авторитет В.М. Истрина, который в специально предпринятом аналитическом разборе этой новаторской концепции подчеркивал ее несостоятельность и даже считал псевдонаучной. Вердикт текстолога категоричен: толкования автора «отличаются большим курьезом», в них нет «никакого анализа редакций и их текста», поскольку «игнорируются самые элементарные правила изучения древнерусских памятников». К.К. Истомин, по заключению Истрина, «стремится быть оригинальным», но обнаруживает «при необычайной самоуверенности только лишь недостаточную подготовленность». Редкие для научной полемики оценки заканчиваются беспощадным выводом: такое начинание «вполне бесполезно» [87, с. 178-195].

Несмотря на суровый вердикт признанного специалиста по палейным редакциям, важные элементы схемы К.К. Истомина недавно использовал в своих построениях болгарский исследователь В.Б. Панайотов. Он считал, что к созданию антииудейского трактата приложил руку Кирилл Философ. Дальнейшая история текста связывалась с Мефодием, который, согласно Панайотову, перевел написанный первоначально на греческом языке текст и его славянскую версию разделил на восемь частей. Этот продукт «сотворчества» солунских братьев Панайотов определял как протограф ТП. Исследователь полагал, что на следующем этапе своего существования текст был дополнен хронографическими данными. В Х в., по его мнению, создавалась сокращенная редакция Палеи. Затем на основе полного и сокращенного вариантов и появился текст, который в древнерусской книжности представляет Коломенская Палея [167; 168; 169].

Отношение в научных кругах к такого рода идеям неоднозначное. На болгарской почве для исследователей-земляков конкрет- 
ные звенья этой схемы выглядят привлекательно, а с позиций представителей русской школы текстологии восприятие их вовсе не комплиментарное. По оценке Е.Г. Водолазкина, который хорошо знает предмет и на протяжении последних лет занимается редакциями Палеи, «выводы исследователя оказались столь же смелыми, сколь малообъяснимыми. <...> Ничего из того, что можно назвать в традиционном смысле научным исследованием, не удалось обнаружить ни в одной из доступных мне публикаций В. Панайотова по палейной теме» [50, с. 15].

В историографии, по вопросу соотношения отдельных редакций Палеи, наиболее распространенной является концепция В.М. Истрина, хотя нельзя сказать, что его выводы остаются единственными и незыблемыми. У него имеются как сторонники, так и противники. Но при этом у многих исследователей отдельные базовые положения данной концепции фигурируют как рабочие. Некоторые положения этой концепции используют даже критически настроенные к выводам Истрина болгарские исследователи, пытаясь согласовать их с идеями то Шахматова, то Панайотова. Принципиальные расхождения авторов, реконструирующих историю бытования палейных текстов, касаются решения проблемы протографа и его датировки. В среде болгарских исследователей активным образом разрабатывается и аргументируется высказанная еще в XIX столетии гипотеза о существовании исчезнувшего болгарского протографа ТП.

Ярчайшим примером является самое объемное и фундаментальное на сегодня исследование ТП, осуществленное в Болгарии Т. Славовой. По сути дела, ее работа посвящена доказательству существования несохранившегося древнеболгарского протографа древнерусской редакции ТП, представленной списками т. н. Коломенского типа [188]. Исследовательница предупреждает, что дифференциация палейных редакций не входит в задачу ее изысканий [188, с. 20]. Однако в деле реконструкции древнейшего прототипа ТП обойти этот вопрос невозможно, поэтому автор книги время от времени возвращается к существующим в литературе трактовкам взаимоотношения редакций, выстраивая на этот счет собственные соображения. Картина взаимоотношений палейных типов, естественно, по причине формулирования самых предварительных суждений о характере исторической эволюции первоначального текста, выглядит гипотетичной, о 
чем и предупреждает автор. Вместе с тем суждения эти важны для понимания общего взгляда исследовательницы на проблему.

Т. Славова категорически противопоставляет свое видение истории палейных текстов концепции Истрина-Михайлова. Из предшественников болгарской исследовательнице ближе всего взгляды А.А. Шахматова. Часть его выводов Славова приняла. Вслед за ним болгарская исследовательница называет Толковый тип первой русской редакцией, а ХП - второй. Как видим, в этой части схема B.M. Истрина, как она была воспринята Шахматовым, продолжает работать, правда с сильной болгарской спецификой. Пиетет по отношению к А.А. Шахматову обусловлен общим пониманием болгарского происхождения ТП.

Наиболее ранним русским палейным текстом Т. Славова называет Коломенский тип, на основе которого создается вторичная по отношению к нему ХП [188, с. 347]. На такое развитие текста, по наблюдению исследовательницы, указывают остатки толкований, которые в составе ХП не могут свидетельствовать о ее первичности. На более позднее происхождение ХП указывает и появление апокрифических сюжетов: о рождении Азуры и Асуам, о смерти и погребении Авеля, апокриф о Аврааме, внеканоническая история Мельхиседека, сказание о Соломоне и Китоврасе, суды Соломона, о царице Савской [188, с. 26].

К Коломенскому типу, кроме самой Тр. № 38 и потерянных рукописей, по которым к ней подводились разночтения при публикации, Т. Славова относит Александро-Невский список, Кир.-Бел. № 68/1145 и список 1549 г. Австрийской национальной библиотеки (Cod. slav. 9) ${ }^{\mathbf{1 2}}$. При анализе содержания исследовательница оперирует коломенским и австрийским текстами памятника.

Детально характеризуются в книге Т. Славовой признаки авторской работы над текстом. На большом количестве конкретных приме-

12 К другим спискам ТП исследовательницей относится перечень из 24 рукописей, которые известны автору по литературе и описаниям собраний. Воспроизводится так же перечень списков ХП и КХП. Перечни требуют уточнения, ибо к толковому типу отнесена ГИМ Барс. № 619, которая связана с появлением ХП, а ГИМ Чуд. № 348 из списка ХП представляет, по наблюдениям А.Ю. Козловой, т. н. Промежуточный, или «средний» тип. Наиболее полный на сегодня список палейных текстов нуждается в дифференциации (например, ГИМ. Барс 619 и Барс. № 620 хотя и имеют схождения, но относятся к разным видам Палей). 
ров хорошо показан творческий характер работы автора-составителя и комментатора ТП, который отбирал и соединял вместе разные по жанру переводные, а также оригинальные источники, решая масштабную задачу создания грандиозного по замыслу и объему труда. Воспроизведенные в книге текстовые примеры наглядно демонстрируют, что составитель, наряду с буквальной цитацией, широко пользовался пересказом и органично комбинировал библейские и небиблейские тексты, дополняя их собственными толкованиями и полемическими выпадами. Нельзя не согласиться с автором монографии, что с учетом единых по стилю толкований и мастерского дополнения буквализма свободным авторским переложением привлекаемых источников создателя ТП нельзя рассматривать как простого начетника, цитировавшего и подбиравшего извлечения из авторитетных в Церкви писателей. На почве обычной для христианской книжности компилятивности безымянный составитель заявил о себе как о большом и талантливом книжнике, как о человеке широкого литературного кругозора и глубоких богословских познаний [188, с. 335, 338-339, 347-348].

В ином ключе, по наблюдению Т. Славовой, трудились составители ХП. К этому выводу она приходит на основании сопоставления разных типов палейного повествования. Из главы в главу по ходу исследования осуществляется сравнение толковой версии Палеи с хронографическим и кратким хронографическим ее вариантами. По одной и той же модели сравниваются параллельные места в разных редакциях. Это дало основание автору для выводов, что в большей части небиблейских источников наблюдаются совпадения ТП с ХП при одновременном незначительном сокращении толковательной части. Признается правота В.М. Истрина, отмечавшего использование ТП при составлении ХП. Согласна болгарская исследовательница и с тем, что апокрифы включены в хронографическую версию позже, правда, насчет датировки у нее отличное от русского исследователя мнение, о чем речь пойдет ниже. Отмечается механическое исполнение работ сводчиками ХП по наполнению обширной компиляции материалами. Совершенно справедливо резюмируется, что хронографически-палейный синтез проигрывает своей умело скроенной предшественнице. КХП расценивается как вторичная и сокращенная версия ХП, в которой от толковой части остались самые незначительные следы [188, с. 346-347]. 
Интересно решается вопрос о прототипах ТП. В своих суждениях исследовательница исходит из того, что конкретных византийских образцов подобного рода литературы нет. Но есть целый ряд полемических произведений антииудейской направленности как в переводной, так и в оригинальной книжности. По мнению болгарских ученых, древние болгарские книжники выстраивали полемику по примеру греческих экзегетов (Иоанна Златоуста, Феодорита Киррского и др.). Из произведений греческой книжности заимствовались и характерные для ТП приемы объяснения Ветхого Завета в новозаветном духе. В этом смысле влияние Византии рассматривается как опосредованное. В Болгарии, как подчеркивается, существовали собственные исторические предпосылки для появления подобных произведений. Антииудейская полемическая заостренность объясняется в монографии реакцией на конкретную религиозную ситуацию в стране, а именно - на встречу болгар с хазарскими переселенцами. Как следствие, появлялись и авторы, которые отвечали на подобные запросы (Слова Климента Охридского, 42 Беседа Константина Преславского, описание полемики с хазарским иудеем в Пространном «Житии Кирилла»). Приоритет Болгарии в деле ответа на соответствующие вызовы для Т. Славовой очевиден. Предпосылок же для создания антииудейского полемического сочинения на Руси к XIII в. - времени предполагаемого создания русским автором ТП - она не усматривает [188, с. 317-324, 340-342].

Значительный объем работы посвящен библейскому ядру ТП, что можно считать вполне самостоятельным исследованием как палейных, так и внепалейных текстов Восьмикнижия и Царств. В книге показано, что последние воспроизводятся в ТП в сокращенном объеме, но при этом перевод библейских текстов идентичен внепалейным древнерусским спискам XIV-XV вв. Известная близость ветхозаветных палейных чтений русским спискам не является для автора основанием считать сами тексты русскими по происхождению. Редакция переводов библейских книг, как полагает исследовательница, существовала веками, а первоначальный ее вид является результатом работы древнеболгарского книжника. В исследовании сделан вывод о том, что паремийные чтения, которые Михайлов считал русскими, близки «Архивскому хронографу» и сохранили следы глаголицы. Признаки древности в грамматике и лексике указываются и в непаре- 
мийных чтениях русской группы Восьмикнижия и Царств. На огромном материале Т. Славова показывает, что древнерусские библейские тексты несут в себе следы староболгарского происхождения. Лингвистические архаизмы, по убеждению автора, указывают на существование древнеболгарских архетипов, к которым восходят русские списки. Скрупулезным образом проведенные текстовые сопоставления послужили основанием для заключения, что привлеченные при создании ТП библейские тексты имели болгарское происхождение, а принятый многими палеистами вывод А.В. Михайлова об использовании составителем ТП русской редакции книг Бытия неправомерен [188, с. 41-126, 335-337]. Аргументация, при всей ее объемности, недостаточна. В недавнем отклике на труд Славовой внимание заостряется на том, что никто не сомневается в древности болгарских переводов библейских текстов из древнерусских списков, но сами по себе наблюдения над подобного рода спецификой не могут свидетельствовать о раннем происхождении ТП. Суть русской редакции состоит в соединении болгарского четьего текста с болгарским же паремийным, что не могло произойти ранее XIII столетия [50, с. 10].

Самым подробным образом в болгарской монографии интерпретируются небиблейские источники ТП, которыми дополнялось повествование ветхозаветных книг с целью истолкования скрытого в них смысла. Например, фрагменты «Шестоднева» Иоанна экзарха Болгарского рассматриваются как один из основных источников шестодневной части древнейшей Палеи. Если для сторонника греческого происхождения это была добавка на русской почве [209, с. 127-128], то для болгарской исследовательницы нет сомнений в том, что болгарский составитель Палеи вскоре после завершения труда Иоанном экзархом непосредственно использовал его «Шестоднев» для своего труда [188, c. 176-177]. Аргумент в данном случае следующий: если бы дополнение осуществлялось русским автором, то части повествования имели бы стилистические отличия [188, с. 176-177].

По языковому критерию оцениваются оригинальные тексты составителя. Вопреки русскому происхождению списков с характерными для них русскими особенностями, они не считаются делом русского автора. В своих суждениях Т. Славова исходит из того, что русизмы характерны для всего пространства памятника, а не только для авторских разделов. В этом усматривается отпечаток бытования памятника на русской почве, 
причем отпечаток равномерно присутствующий во всем произведении, а не только в авторском тексте. Это русское влияние оценивается как позднее, ядро же самого произведения с его авторскими комментариями, возводятся к раннему болгарскому наречию. Языковые архаизмы, по заключению болгарской исследовательницы, не дают основания считать сборник русским. Вывод на основе этого категоричен: все говорит о том, что автором ТП был староболгарский книжник [188, с. 339, 343].

Другой аргумент - увязка некоторых фрагментов с Пространным «Житием Кирилла». Вводя это произведение в круг непосредственных источников болгарского протографа ТП, Славова развивает идеи Шахматова и Панайотова $[215$, с. 216; 169, с. 78-81]. Весь пафос исследования сводится к обоснованию идеи раннего болгарского автора. Делается вывод, что «Житие Кирилла» было среди источников составителя. Доказательство не текстологическое, а сугубо ассоциативное: фрагмент жития представляет собой единое смысловое целое с палейным повествованием. Возможность русского начала даже не рассматривается, а аргументы Истрина, который связывал эти полемические мотивы с творчеством русского автора, по существу, не отводятся в порядке научной полемики.

В том же ключе ведется рассказ об апокрифических вставках в палейный текст [188, с 260-270]. Исследовательница приводит один и тот же стандартный аргумент в пользу изначальности того или иного апокрифического элемента ТП, ссылаясь на его присутствие в древнейших списках, а также в списках других редакций памятника, но это совсем не текстологический аргумент, а своего рода расширенная справочная информация.

На страницах книги разворачивается широкая панорама литературных источников ТП, как переводных, так и оригинальных. К числу непосредственных источников протографа ТП среди прочих относятся извлечения из «Богословия» Иоанна Дамаскина в переводе Иоанна экзарха Болгарского, что другими исследователями не отмечалось (ангелология и расположение планет, порядок которых, кстати, иной, чем в «Богословии») [188, с. 178-182]. Аргументируется раннее включение данного источника в палейную компиляцию только тем, что заимствование из переводов Иоанна экзарха указывает на страну составителя, а соответственно и на время, когда тот работал. Правда, в контексте споров о происхождении и датировке памятника это не представля- 
ется очевидным хотя бы потому, что к XIII в., которым традиционно многие из исследователей датируют появление ТП, этот перевод на Руси был так же известен (ГИМ Син. № 108) [185, с. 162-163].

По аналогии с выдержками из «Богословия» интерпретируются извлечения из «Христианской топографии» Козьмы Индикоплова [188, с. 187-194], из «Хроники Иоанна Малалы» [188, с. 226-227], а также хронографических сочинений Георгия Амартола [188, с. 228-230] и Георгия Синкелла [188, с. 231]. Исследовательница отталкивается в своих рассуждениях от того, что некоторые предшествующие авторы и ранее считали указанные пассажи составными частями компилятивных блоков, включенных в ТП. Сама Славова полагает, что существовал некий болгарский компилятивный фонд, из которого по отдельности указанные фрагменты текстов были заимствованы. Критерием болгарского происхождения являются языковые признаки анализируемых сочинений. Появление переводов вышеперечисленных произведений она относит ко времени наибольшей литературной активности болгарских книжников, а именно к эпохе царя Симеона. Некоторые из переводов датируются концом IX в. Исследовательница признает наличие русской лексики в текстовых фрагментах, но отказывается видеть в этом какое-либо участие русского автора [188, с. 337-338].

К сожалению, доводы В.М. Истрина, который в тех же самых случаях связывал первоисточник заимствований с хронографическими компиляциями, не рассматриваются. Доказательных аргументов по опровержению выводов скрупулезного текстолога в монографии не обнаруживается. По поводу заимствований в ТП из «Христианской топографии» просто заявлен тезис, что соответствующие фрагменты восходят к болгарскому переводу произведения. Как и в случае с «Хроникой» Георгия Амартола, исключается сама возможность посредничества русских хронографических компиляций. Хотя древнеболгарские параллели названных хронографических текстов неизвестны, достаточным основанием считается наличие соответствующих фрагментов в древнейшей группе списков ТП. Затем объем их прослеживается в составе ХП и КХП.

В книге Т. Славовой один и тот же прием оценки компонентов древнейшей Палеи стереотипно повторяется из раздела в раздел. Исключения не делаются для таких понятных текстов, как толкова- 
ния Феодорита Киррского на Пятикнижие. Последние даже Истрин, имевший, в отличие от исследовательницы по большинству позиций иную точку зрения, сопоставлял со славянским переводом из сборника Кааф в составе «Изборника XIII века». К первоначальному составу данные толкования относятся исключительно на том основании, что текст этот читается во всех списках ТП, включая ХП, где он сокращен как вторичный. Отмечается наличие южнославянских лексем, на основании чего и делается вывод, что толкования были известны болгарским книжникам, а сам перевод датируется X в. [188, с. 212-222].

Ту же методику наблюдаем в вышедшей вслед за монографией статье Т. Славовой, где она рассматривает фрагменты «Златоструя» и «Слово Ипполита об антихристе» в качестве первоисточников болгарского протографа ТП. Датировка и приемы обоснования болгарского происхождения внебиблейских источников Палеи и в статье, и в исследовательских разделах книги написаны стереотипно и, к сожалению, не заменяют собой аргументацию. Примеры можно продолжить.

Т. Славова полагает, что источником внебиблейских заимствований в протограф ТП была староболгарская энциклопедия, которая своим составом покрывала суммарное содержание «Симеонова сборника» (по списку «Изборника Святослава 1073 года») и несохранившегося «Архивского хронографа». Принципы толкования взаимоотношения внепалейных источников и хронографических сведений выглядят достаточно необычно для аналитического труда. Автор ставит задачу выяснить взаимоотношения между ТП и «Архивским хронографом», точнее, не сохранившимся его староболгарским протографом. Основанием для сближения обоих памятников, по убеждению автора, является то, что они создавались на основе единого книжного фонда: Библии, разных хроник, текстов Иоанна Златоуста, благословения Иакова, апокрифических сведений об идолопоклонстве при Серухе и Нимроде, «Заветах двенадцати патриархов» и других источников [188, с. 270-273]. Приводится подробная таблица совпадений [188, с. 274-275]. Автор специально объясняет, что нельзя ожидать полноты совпадений как в заглавиях, так и со стороны материала статей, ибо они заимствовались из единого источника, но подчинялись разным задачам: ТП - задачам обличения иудаизма, а хронограф являл собой сугубо историческое повествование. Автор предлагает 
устанавливать соответствия между памятниками не на текстовой, а на содержательной основе. Но даже и в этом случае гипотетический продукт Преславского книжного центра предстает в чертах разножанровости и возникают вопросы: как могли быть объединены богословские и исторические разделы в рамках предполагаемой компиляции, каким образом взаимодействовали между собой параллельные сюжеты? Вопрос о жанре, специфике и возможных прототипах болгарской компиляции представляется неразрешимым, а с точки зрения доказательности вряд ли можно считать достаточным замену текстологических аргументов общими соображениями.

Стремление расширить круг древнеболгарских источников ТП порой выглядит неоправданно тенденциозно. Перечень русских рек и соседних со славянами племен, примыкающий к таблице народов, рассматривается просто как позднейшее наслоение, совпадающее с рассказом «Повести временных лет» [188, с. 277]. В соответствующем разделе все внимание сосредоточивается на демонстрации близости переводных пассажей о народах их греческим оригиналам [188, с. 224-227]. А ведь здесь наиболее наглядно проявляется работа составителя. Совершенно понятно, что весь текстовой блок, восходящий к переводам, вместе с этой вставкой никак не может иметь древнеболгарское происхождение. Хронографический сюжет о расселении потомков Ноя, включая восточных славян и их ближайших соседей, не мог появиться ни у болгар, ни у греков, от которых в славянскую среду приходили хроники с соответствующим сюжетом. Иначе надо признать русское происхождение всего блока о народах и племенах. Недавно Т. Викул в своем исследовании палейного сюжета о расселении народов отметила, что Т. Славова абсолютизирует хронографы и игнорирует зависимость Палеи от летописи. Дело даже не в глоссе о соседях славян - весь палейный пассаж с перечислением «языков» зависит от «Повести временных лет», этнографические сведения которой являются основой для комбинирования с заимствованиями из хронографической компиляции [41, с. 50].

ТП рассматривается Т. Славовой исключительно в контексте болгарской культуры. И работа составителя, и само накопление источников для труда связываются исключительно с Болгарией [188, с. 343]. Общий ход рассуждений в этом направлении выглядит следующим образом. Состав списков Коломенского типа не идентичен болгар- 
скому протографу. Соответственно позднейшие наслоения с русской спецификой (как в сюжете о расселении народов) попросту исключаются из рассмотрения. Однако препарирование тематических блоков на части, дробление их на составные фрагменты далеко не самый перспективный путь. Учитывая специфику средневекового книжного творчества, текстологи чаще оперируют комбинированными текстами как едиными блоками и находят для этого лингвистические обоснования. Здесь же мы видим отход от достаточно развитой традиции текстологического исследования произведения да последовательное проведение линии на атомизацию составных частей, основанную в большей мере на умозрительных, а отнюдь не на текстологических соображениях.

Особого рассмотрения требует предложенная датировка протографа болгарской компиляции. Время возможного составления ТП относится к периоду от конца IX до середины Х в. [188, с. 344]. Т. Славова датирующим признаком считает 921 г., до которого доведен используемый при составлении Палеи хронограф. С этой датой, которой оканчивалось хронографическое повествование, она и связывает проведение работ над сводом славянских источников. На это же, по ее мнению, указывает факт существования на тот момент в Болгарии всех источников палейной компиляции: «Диалогов Псевдо-Кесария», «Физиолога», «Семионова сборника», «Шестоднева», «Парнесиса» Ефрема Сирина, «Краткой хроники патриарха Никифора» и других. Допускается, что протограф ТП был создан вскоре после появления «Архивского хронографа», а конкретно - к концу первой четверти Х в. [188, с. 276-278]. В пользу раннего происхождения ТП обращается и дата «Архивского хронографа».

В хронологических выкладках исследовательницы, относящихся к наблюдениям за бытованием разных палейных типов, обращается внимание на тот факт, что и в ХП и в КХП повествование доведено до смерти Романа Лакапина в 948 г. Со ссылкой на М. Соколова, который включил ТП и ХП в источники «Повести о крестном древе», ставится вопрос о возможном более раннем происхождении хронографической палейной версии. Над «Повестью» поп Иеремия работал до второй половины X в., и эта датировка совпадает с хронологической метой от хронографа. По убеждению Славовой, апокрифические вставки в ХП указывают на вторую-третью четверть Х столетия, ког- 
да подъем еретичества возбуждал интерес к неканонической письменности. Конкретных примеров и датированных этим периодом апокрифов не приводится, но тем не менее возможная дата ХП сдвигается ближе к Золотому веку Болгарской культуры. Соответственно и хронографическую версию Палеи надо тогда отнести на счет болгарских составителей. Но об этом напрямую исследовательница не говорит и ограничивается предварительными, но ко многому обязывающими наблюдениями.

Сама метода хронологических доказательств представляется проблематичной. В качестве аргументации используется уже известный нам по датировке ТП прием с отсылкой к верхней дате хронографических включений в текст. Т. Славова ставит вопрос так: если принять позднее русское происхождение ХП, то странно, почему события не доведены до времени окончания работы русских составителей [188, с. 279]. Магия датировки по позднейшей дате хронографических извлечений столь велика, что во внимание не принимается тот факт, что до 948 г. была доведена сама ХГА, а не ее болгарский перевод. Принятые в работе болгарской исследовательницы за датирующие признаки хронологические метки отражают не вехи работы болгарского книжника, а указывают на годы, которыми заканчивались хронографические повествования, находившиеся в руках у составителя. Ошибочность такого подхода уже была отмечена в отклике на монографию [50, с. 12]. Хронологические рамки греческих хронографов - это одно, а увязывать эти рамки с работой болгарских книжников - это уже совсем другое. Проводить подобные связи неправомерно, тем более что вопрос освоения славянскими книжниками хронографов достаточно разработанный. Отсутствие сведений о русских событиях в Палее, на что обращал внимание еще Шахматов и что вроде бы подтверждает отсутствие связи с русской почвой, свидетельствует лишь о том, что компиляция имела исключительной своей целью всемирную историю. Даже отдельные известия, касающиеся русских и болгар (типа сюжетов о поражении русов при Михаиле и переложении книг при Борисе) присутствуют в палейных текстах исключительно потому, что они являлись частью повествования о важных мировых событиях, находившихся в поле зрения автора «Хроники» Георгия Амартола.

Наиболее интересным и новым в содержании книги является обнаруженная Т. Славовой связь палейных текстов с «Диалогами Псев- 
до-Кесария». Никто из комментаторов ТП на это прежде не указывал, и только архимандрит Леонид без конкретизации отмечал заимствования в ТП из «Диалогов» [127, с. 17; 128, с. XII-XIII ]. В книге Т. Славовой рассматриваются конкретные сюжеты. Обращено внимание на зависимость от переводного источника важных постулатов антропологического раздела (об уме, тайне оплодотворения и развитии младенца), а также объяснение некоторых физических явлений. «Диалоги» расцениваются болгарской исследовательницей как род энциклопедии, служившей для воспроизведения сведений по естествоведению [188, с 183-186; 187, с. 243-251; ср.:213, с. 25, 153]. Т. Славова указала 19 таких сюжетов, а детально рассмотрела из них два. Дальнейшую работу по сравнению проделал Я. Милтенов, который произвел полное текстологическое сопоставление 20 параллельных сюжетов [143, c. 183-196 $]^{13}$. Этому автору принадлежит критическое издание «Диалогов Псевдо-Кесария», публикация которых и послужила материалом для сопоставления параллельных мест с КП. В публикации Милтенова подробным образом проанализированы сохранившиеся списки и их греческие источники, подготовлена солидная эмпирическая база для рассмотрения отношения «Диалогов» с ТП [142]. Это действительно новые данные, которые могут способствовать более глубокому пониманию компилятивного характера ТП, особенно его сложных, комбинированных частей (в нашем случае выяснение комбинации сведений из «Шестоднева» Иоанна экзарха Болгарского и «Диалогов»). В болгарском происхождении Диалогов публикатор древнерусских списков XV-XVI вв. не сомневался [128, с. XII], но вопрос должен уточняться: когда и какими списками пользовался составитель. А здесь уже необходимы лингвистические критерии. Только на основании одного фактора происхождения удревнять осуществление выборки из этого первоисточника в ТП преждевременно.

Монография Т. Славовой насыщена обильной цитацией параллельных чтений и сопоставлением текстовых фрагментов в разных редакциях (видах) Палеи. Но до обидного мало чисто доказательных и замыкающихся на конкретные источники аргументов в пользу выдвигаемых тезисов. При такой обширной цитации разновременных текстов автор

13 В последние годы Т.Ю. Козлова выявила случаи влияния текстов Псевдо-Кесария на ТП, не отмеченные предшественниками. 
как-то обходится без традиционных приемов текстологического анализа. Много не подкрепленных фактурой постулатов, гипотетичности, вкусовых предпочтений при формулировании базовых утверждений ${ }^{14}$. А это, в свою очередь, будет вызывать вопросы и споры.

Убеждающих аргументов для нового взгляда на Палею, особенно в опровержение оспариваемых мнений оппонентов, надо признать, в монографии не находится, несмотря на обширную эмпирическую базу. Книга, без сомнения, представляет собой заметное явление в современной палеистике, а поскольку ключевые вопросы убедительно не разрешены, да к тому же заявленные в книге подходы спорны, дискуссии по ним неизбежны. В этом побуждении к дальнейшему поиску родины ТП и заключается значение монографии.

Критическое отношение к реконструированной В.М. Истриным истории Палеи характерно не только для Т. Славовой и тех оппонентов-современников, которые еще при жизни текстолога вступали с ним в прямую дискуссию.

Вопрос о необходимости правки истринской схемы поставил А.А. Алексеев. Он обратил внимание на необычное содержание Палеи из собрания ГИМ Барс. № 619, которая в описях значилась как ХП. По его наблюдениям, список, который по водяным знакам можно было датировать концом XIV или по крайней мере не позднее начала XV в. (т. е. временем, близким к КП 1406 г.), включает ряд апокрифов, которые читаются в ХП, но которых нет в КП (в частности, «Житие Моисея») [6, с. 64-65; 4, с. 350]. Сопоставляя оба списка, он пришел к заключению, что в Коломенской Палее сохранились следы изъятия апокрифов и правки текста, произведенные на одном из этапов существования памятника. В тексте Коломенского типа исследователь указал на следы освобождения от тех апокрифических источников, которые читаются в хронографических изводах Палеи. Этими следами он считает незначительные остатки апокрифических повествований о дьявольских кознях в ковчеге Ноя, об Аврааме, о Мельхиседеке, о Моисее. После переработки общими оставались только толкования и обличения жидовина, которые также незначительно варьируют

14 На то, что базовые выводы Т. Славовой строятся на неочевидных утверждениях, а последние основываются не на аргументации и заменяются тезисами, указывала в своем отклике на работу болгарской исследовательницы Т. Викул [41, с. 38, 50]. 
между собой по составу и объему. На этом основании исследователь предположил, что обе разновидности восходят к общему оригиналу. Отсюда вывод: считавшаяся Истриным древнейшей Палея не является первоначальной. Она имеет с Барс. № 619 «общего предка» [6, с. 65-67]. Таким образом, А.А. Алексеев подверг сомнению положение Тихонравова-Истрина о последовательном усложнении редакций и опроверг истринскую версию о внесении иудейских легенд в ХП в эпоху «жидовствующих» [6, с. 63-67].

Общий взгляд на Палею в свете сделанных А.А. Алексеевым наблюдений можно представить следующим образом. ТП относится к толковой разновидности библейских книг. Она представлена группами списков, которые можно разделить на ранние и поздние. Указывалось на отличия этих групп списков по составу. Исследователь полагал, что в созданное русским компилятором произведение наряду с извлечениями из библейских книг и «Шестоднева» Иоанна экзарха Болгарского входили мелкие апокрифические отрывки, а из целых апокрифов воспроизводились только «Заветы двенадцати патриархов» и «Откровение Авраама» вместе с несколькими апокрифами о Соломоне. В поздней редакции объем текста увеличился, в том числе в библейской части за счет отрывков из Иеремии и Даниила. Общим материалом оставались антииудейские толкования славянского происхождения. Расхождения с Истриным касались также датировки, ибо появление ТП исследователь относил к концу XIII в. [7, с. 40-41].

Если первоначально автор допускал, что Барс. № 619 и списки Толковой группы имеют общего предка, то в последующих работах появляется иная схема взаимоотношений палейных типов, которые классифицируются по четырем редакциям. К исходному раннему виду ТП исследователем отнесена непосредственно рукопись ГИМ Барс. № 619, представляющая в этой схеме первую редакцию. Вторая включает двенадцать списков, «возглавляемых Коломенским» ${ }^{15}$; «третья и четвертая редакциии Толковой Палеи входят составной частью в дру-

15 КП 1406 г.; Ал.-Невская плюс фрагменты Сильвесторовского сборника XIV в.; Кир.-Бел. № 68/1145 - XV в.; ГИМ Чуд. № 350/18; ГИМ Увар. № 85/286 — копия Ал.-Невского; из собр. Н.С. Тихонравова 1576 г.; из собр. Н.С. Тихонравова XVII в.; из собр. И.Л. Силина - XVII в.; из собр. Е.И. Якушкина - XVII в.; Венской придворной библиотеки № 12 - ныне Cod. slav. 9; РГБ Костр. № $320-$ кон. $\mathrm{XIV}$ - нач. XV в. 
гой памятник - Хронографическую палею: в ее составе ТП образует первую половину, тогда как вторая представляет собой хронограф $<\ldots>$. Третья редакция воспроизводит текст первой редакции, как он известен по Барс., тогда как в четвертой эта часть заметно сокращена и переработана, в ней использованы некоторые новые источники. Принятое в науке название для этих двух компиляций отражает характер двух главных составляющих ее частей: третья редакция называется Полной хронографической палеей ${ }^{16}$, поскольку с хронографом здесь соединяется Палея в своем полном объеме; четвертая редакция названа Краткой хронографической палеей ${ }^{17}$, поскольку здесь с хронографом соединена Палея в кратком виде. Две эти компиляции возникли независимо друг от друга» [2, с. 42-43; 3, с. 32].

Как видим, вводя новое звено, А.А. Алексеев в остальном воспроизводит схему В.М. Истрина, в общем принимая датировку создания ТП XIII в. и выражая уверенность в русском происхождении всей компиляции. Согласно исследователю, важным признаком было отсутствие во второй (Коломенской) редакции «апокрифов, заимствованных непосредственно из еврейских источников» [2, с. 43]. Подробно разбираются древнерусские переводы еврейских апокрифов со следами гебраизмов и их возможные источники («Житие Моисея», обширный цикл о Соломоне и Китоврасе, включая суды Соломона и историю его взаимоотношений с царицей Савской). Околобиблейские легендарные истории, по заключению исследователя, не переводились специально для ТП, но, попав в нее, были исключены из списков Коломенской группы. Они сохранились только в одном списке ТП, а именно - в Барс. № 619 [2, с. 56].

А.А. Алексеев предлагает и объяснение, почему редакция Барсовской Палеи отличается от редакции палейных списков Коломенского типа полнотой апокрифических текстов и большей полнотой библейских сведений. Он обращает внимание на талмудические источники ветхозаветных апокрифов и на то, что они были включены в ТП вместе с антииудейской полемикой. В такой «упряжке» исследователь видит причину благочестивого намерения составителя

16 К ПХП отнесены Рум. № 361, Рум. № 453 - 1495 г., Чуд. № 348 - XVI в., Пог. № $1435-$ XVI в., Син. № 210, Син. № 211, Унд. 719.

17 К КХП: Пог. № $1434-\mathrm{XV}$ в., Пог. № $1436-1590$, РГБ. Долг. № $1-$ кон. XV - нач. XVI в., Волок. № 551., РНБ. F. IV.603 - XVII в., Сол. № 866/ 977. 
КП «уравновесить сомнительный в доктринальном смысле материал апокрифов подчеркнутым отмежеванием от той еретической интерпретации Писания, какую предлагал через него иудаизм» [3, с. 31]. По причине такой внутренней связи между иудейскими источниками и антииудейской полемикой в составителе-полемисте Алексеев склонен видеть чуть ли не выкреста, не вполне обычный тип комментария, который похож на еврейские толкования типа мидрашей. При этом знакомства с еврейской письменностью и иудаизмом в авторских дополнениях не выявлено, наоборот, отмечено плохое знание еврейской истории. Причина последовавшего редактирования объясняется стремлением освободиться от сомнительных текстов.

Новым в схеме А.А. Алексева является не просто количество звеньев в истории бытования древнерусских палейных текстов, а выделение некой исходной основы с апокрифическим талмудическим ядром. Если прежде считалось, что в процессе создания ХП в нее были включены талмудические апокрифы и этим она отличалась от Коломенской Палеи, которая была свободна от этого элемента, то после обнаружения таких апокрифов в Барсовской Палее и их остатков в ТП исследователь сделал вывод об удалении неканонических текстов из протографа Коломенской группы списков. В этом его убеждал и состав Ал.-Невской Палеи - древнейшей из списков этой группы [3, с. 29].

Проделавший большую работу по выявлению еврейских источников автор в данном случае отступает от доказательной аргументации текстами и о взаимоотношении списков начинает судить по внешним признакам, а именно по их датировке. Однако хорошо известно, что часто более поздние списки дают первоначальные чтения. Без объяснения оставлено и «возвращение» талмудических апокрифов в ХП. «Нетипичная» Барс. № 619, послужившая поводом для пересмотра концепции Истрина, действительно обнаруживает в своих чтениях пересечения с КП и с ХП. Но, как удалось показать Е.Г. Водолазкину, это отнюдь не является основанием для выявления нового звена в истории развития палейных текстов. Сохранившиеся на страницах Барсовского списка метки позволяют составить представление о работе над компилятивными частями будущей ХП, при создании которой Барсовский список служил своеобразным черновиком. Поэтому предложенные А.А. Алексеевым доводы, по заключению Е.Г. Во- 
долазкина, не дают оснований для пересмотра истринской схемы [50, с. $15-19 ; 46$, с. $327-353 ; 47$, с. 175-198].

Чтобы составить полное представление о новейших тенденциях в палеистике, необходимо подробно остановиться на выводах и аргументах Е.Г. Водолазкина, который на протяжении последних лет целенаправленно и углубленно занимается изучением палейных текстов разных видов [43-51]. Эти работы, как, впрочем, и работы предшественников, со всей наглядностью показывают, что проблемы ТП не могут быть разрешены без учета истории развития и сопоставления типов палейного повествования.

В своих работах Е.Г. Водолазкин подытоживает полуторавековую историю палеистики и ставит ряд важных проблем на перспективу. В плане итогов им суммируется и критически оценивается спектр подходов к изучению палейной тематики в трудах предшественников, о чем неоднократно приходилось говорить выше. Главной проблемой, тормозящей всестороннее изучение Палеи, исследователь считает отсутствие качественных публикаций текстов и ставит задачу ввести списки основных палейных типов в научный оборот. На путях решения этой задачи им предпринимается издание КХП по списку РНБ Пог. № 1434 с разночтениями по пяти спискам [48, с. 175-198; 49, с. 341-349]. Отбор источников для публикации предваряло детальное тектологическое исследование краткого типа ХП [52, с. 164-180].

Е.Г. Водолазкин сожалеет, что полную публикацию ХП невозможно осуществить в ближайшее время, а частично издававшийся список Син. № 210 плохо подходит для работы, поскольку не отражает первоначального вида. По его мнению, с ТП, несмотря на имеющиеся издания, дело обстоит не вполне благополучно. Признавая популяризаторское значение публикации А.М. Камчатнова, который предложил способ интерполированного воспроизведения текста, Водолазкин солидаризируется с критическими замечаниями Н. Трунте и полагает, что «научное применение этого издания весьма ограничено» [50, с. 4-5; ср.: 226, S. 440-445]. Это заставляет исследователя ориентироваться на дореволюционное издание, которое также не во всем его устраивает. Суть дела объясняется следующим образом: Коломенская Палея, положенная учениками Н.С. Тихонравова в основу публикации в качестве основной, выбрана неудачно и не дает полного представления об особенностях Толкового типа. Но при этом подчерки- 
вается, что текст введенных в научный оборот списков Коломенской группы отличается высокой стабильностью, поэтому вновь обнаруженные рукописи не способны изменить текстологической картины. В итоге в качестве эмпирической основы для характеристики ТП берется текст Тр. № 38 с разночтениями к нему по девяти спискам [50, с. 3].

Важнейшей задачей на перспективу Е.Г. Водолазкин считает проведение текстологического изучения ТП, без чего нельзя прийти к убедительному заключению о происхождении Палеи и невозможно выяснить соотношение редакций. В своих построениях исследователь считает категорически доказанной и незыблемой концепцию Истрина-Михайлова. Он решительным образом принимает их аргументацию и с этих позиций критикует К.К. Истомина, Т. Славову и В. Панайотова. Попытку некоторого движения в сторону взглядов Истомина в текстологических построениях А.А. Алексеева он так же отводит, доказывая ошибочность выхода за рамки схемы Истрина-Михайлова. Выводы Алексеева принимаются только в части заключения об отсутствии связи между появлением талмудических апокрифов в палейном тексте и ересью жидовствующих [42, с. 35-37; 50, с. 2, 9-13, 15; 46, с. 329-335]. Вслед за своими предшественниками Е.Г. Водолазкин исходит того, что существовало три типа Палей, и не удостаивает внимания так называемый помежуточный вид, только отмечает, что его не принял В.М. Истрин [50, с. 3; 46, с. 328].

Санкт-петербургский исследователь предпринимает специальные текстологические изыскания в направлении конкретизации истории развития русской палейной традиции. С опорой на внепалейные параллели и на выявление чтений, близких ТП, автор наглядно показывает, как осуществлялось соединение материалов из разных источников и как в результате появлялась иная разновидность палейного повествования. По сути дела, детально реконструируется появление нового палейного типа. Отслеживая специфические редакторские метки в тексте рукописи Барс. № 619, Е.Г. Водолазкин уточнил, как шла работа с выписанными в нее фрагментами ТП и распространенными текстами, характерными для ХП.

Ключ дала история Иосифа Прекрасного. Ориентируясь на значки против текста, которые соответствуют сокращенному фрагменту из ТП, он такие же значки обнаружил против извлечения из текста Ефрема Сирина об Иосифе. Становилось понятно, каким образом 
редактор соединял исходные материалы. Объединение отмеченных метками текстовых фрагментов, с добавлением извлечений из Книги Бытия, в сумме давало объем чтения ХП [46, с. 335-336]. Та же специфика выявлена и при детальном изучении других фрагментов Барсовской рукописи. Например, апокрифический сюжет о мыши в ковчеге Ноя вошел в Барсовскую рукопись в соединении с повествованием о Ное из ТП. В этой части повествования материалы Барс. № 619 не только проясняли способ составления пространной палейной компиляции, но и дали основание для датировки апокрифического сюжета началом XV в. - временем более ранним, чем считалось до этого [46, с. 341-347, 352; ср.: 134, с. 159-160; 97, с. 106]. Аналогичным образом анализируются и другие сюжеты, в составе которых наряду с палейными выявляются и расширявшие чтения ТП внепалейные источники. Последние, в частности, характерны для повествования об Аврааме и Мельхиседеке [47, с. 175-183].

Наблюдение за структурой текста Барсовского сборника и текстовыми особенностями включавшихся в него статей позволили автору установить конкретные или наиболее вероятные источники заимствований. Так, в тексте из «Жития Моисея» были обнаружены признаки, свидетельствующие о том, что текст взят из сборника, предназначавшегося для чтения вслух. Таковым, по заключению текстолога, мог быть «Златоуст» типа Пог. № 947. К этому же «Златоусту» возводится и «Слово Ефрема Сирина об Иосифе Прекрасном» [50, с. 19].

Важное значение для понимания истории развития палейной традиции имеют Прибавления к Палее. Они публиковались в качестве приложения к «Летописцу Еллинскому и Римскому» и, по заключению О.В. Творогова, важны для выяснения взаимоотношений между ТП и ХП [129, с. 201-206; 199, с. 21]. В статьях Водолазкина показано, что список Барс. № 619 отличается от Полной ХП тем, что в нем имеются Прибавления, но еще отсутствует продолжение на основании «Хронографа по великому изложению». Это дает основание считать редакцию Полной, но еще не Хронографической [50, с. 21]. Состав Барс. № 619 отражает попытки распространить и продолжить первоначальный текст. Результатом подобного рода усилий и стало в итоге создание Полной ХП, в которой осуществилось смешение жанров палейного толкового и хронографического. Этого смешения не допускал редактор Барсовского списка, что позволяет всецело рассматри- 
вать его в рамках палейной, а не хронографической традиции. Иную задачу, но уже на основе использования преимущественно хронографических материалов, решал создатель КХП, придавая сокращенным палейным текстам хронографическую окраску. По сравнению с ними полная ХП жанрово была «текстом-кентавром».

Если при рассмотрении взаимоотношения палейных типов Е.Г. Водолазкин концептуально следует за Истриным, то временные рамки истории бытования Палеи, на основании привлеченных к анализу списков, ему видятся по-своему. Создание ТП относится к концу XIII столетия [50, с. 21]. Правда, в другой своей работе он считал, что предпочтительнее датировать создание ТП началом XIV в., хотя и не исключал конец XIII столетия [47, с. 193]. На основании Барсовского списка создание XП относится к рубежу XIV-XV вв., а возникновение краткой версии Палеи датируется 40-ми гг. XV в. [50, с. 21]. Как видим, автору свойственно хронологически ужимать время между сложением первоначального вида и появлением комбинированных версий памятника. Это позволяет ему связывать появление ХП и КХП, т. е. двух разновидностей хронографического типа, с деятельностью общего для них книжного центра, который специализировался на палейных переделках.

Присущую палейным текстам мозаичность Е.Г. Водолазкин склонен рассматривать как свойство, затрудняющее понимание памятника. Эта установка не имеет отношения к выявлению составных частей. Как раз в этом направлении содержание изучается досконально. С точки зрения исследователя, ввиду компилятивности ТП проблематичен религиозно-философский анализ памятника. Объясняется это тем, что выборка из сочинений разных авторов чревата столкновением разных точек зрения в комбинированном повествовании. Составные разделы, по убеждению автора, неизбежно будут транслировать «следы прошлых эпох». Без приведения конкретных примеров настороженное отношение к памятнику распространяется и на все другие произведения христианской эпохи: «...противоречие в пределах одного памятника для средневекового текста явление обычное», - делает заключение автор [50, с. 7]. На том основании, что «всякое обобщение применительно к средневековой компиляции таит для исследования немало опасностей», необходимость, возможность, да и сами основания философской интерпретации Палеи ста- 
вятся под сомнение. Если следовать логике Е.Г. Водолазкина, то надо отказаться от оценки древнерусской мысли и мыслителей вообще, так как ни в оригинальных, ни в переводных текстах нет «чистого» авторского текста.

Предпочтения, отдававшиеся славяно-русскими книжниками представителям разных богословских школ, несмотря на присутствие мозаичной смеси в большинстве текстов, обычно проводились. Под покровом компилятивности текстов просматривается их смысловой стержень, интерпретируя который можно говорить о сближении или расхождении позиций мыслителей, а также об их принадлежности к разным идейно-религиозным течениям. За скепсисом кроется априорное недоверие к богословской квалификации составителя Палеи, которому, таким образом, отказывают в понимании сути расхождений между разными направлениями экзегезы. Ведь если согласиться, что мозаичность представляла собой хаотичное смешение разных интерпретаций, то таковым же неразборчиво-хаотическим должно было бы быть мировоззрение сначала составителя, а затем и потребителей его творчества. Составитель Палеи в вопросах мироустройства и локализации рая однозначно демонстрирует приверженность антиохийской школе богословия. Обращаясь к текстам представителей разных богословских школ, составитель сумел избежать внутренних противоречий и столкновения в пределах компиляции разных точек зрения. Цитируя, к примеру, геоцентристов, представлявших каппадокийское богословие, он это делает так, что нигде не подрывает последовательно проводимого принципа плоскостно-комарного мироустройства [146, с. 39-68]. Другой пример - Иоанн экзарх Болгарский, который широко заимствовал материалы из Шестодневов, написанных авторами-антиохийцами, но от этого не переставал быть приверженцем защищавшейся каппадокийскими экзегетами геоцентрической версии мироздания [12, с. 29-38]. С учетом этого нельзя не обратить внимание на то, что степень антикизации при трансляции в Палею сведений из Шестоднева Иоанна экзарха «угасает» едва ли не под влиянием буквалистского подхода к трактовке бытия, характерного для методы антиохийского богословия [148].

Уровень авторов-составителей славянских и древнерусских компиляций был высокий и позволял избежать эклектики в богословских нюансах, даже когда текст комбинировался из фрагментов, взятых из 
трудов представителей разных школ экзегезы. Отказ давать оценку идейно-религозной специфике текста, ограничиваясь общими указаниями на его доктринальную апологетичность, заведомо упрощает и унифицирует духовную жизнь в стране. Противопоставление задач источниковедения и текстологии задачам философской герменевтики содержания ведет к смещению центра тяжести на изучение формы за счет пожертвования смыслами. Получается, что формальная сторона памятника, его языковые и грамматически особенности, лексические варьирования от списка к списку, следы разнообразных влияний и заимствований на фоне реконструированного мозаичного узора самых разнообразных источников превращается в самоцель. Тогда только и остается все смыслы сводить к обобщенной апологетике христианской доктрины. К какой школе экзегезы составитель склонялся, как работал со своими неоднозначными источниками, чтобы провести собственную линию предпочтений, - все это при такого рода подходе выносится за рамки оценок памятника.

Может быть, в такой форме выражена убежденность, что богословие в принципе исключает возможность любого соприкосновения с философией? Но этот сформированный стереотипами новоевропейской философии подход давно преодолен, и средневековая религиозная мысль разных стран плодотворно изучается с религиозно-философской точки зрения. Объектом такого анализа стало и древнерусское наследие. Противники историко-философского подхода к религиозному материалу есть как среди философов, так и в богословской среде. С учетом очевидного византийского влияния на Русь, где философия продолжала свое существование в рамках богословия, градус скептицизма заметно ослабевает.

Целенаправленное ограничение задач исследования богатейшего по содержанию древнерусского памятника и тем более игнорирование базовых смыслов философского значения в мировоззренческиустановочном тексте не может быть принято. Даже если текст эклектичен, необходимо ответить на вопрос: как такой текст работает при воздействии на читателей и какие установки в сознании он формирует. Ведь предлагаемое для компиляции смешение оттенков в трактовке религиозных постулатов неизбежно должно переноситься в головы. Но никто не сомневался в строгости изложенных в Палее истин. Тогда какой смысл в скепсисе относительно мозаичного состава 
компиляций? Предлагаемый подход по сути своей смыкается, как это ни странно, с прямо противоположной исследовательской тенденцией, для которой характерно игнорирование сложной архитектоники компилятивных трудов, подобных Палее. При таком подходе тоже господствуют усредненные оценки, только автора-составителя «заставляют» говорить не своими словами, но как бы от себя. Подобный подход наблюдается у «неофитов палеистики», которые обращаются к темам без учета того, что было сделано на этом проблемном поле и без соотнесения с идеями цитировавшихся в компиляции богословов ${ }^{18}$. Невнимание к тому, что принадлежит автору, а что его источникам, уводит в сторону от того, что реально хотел своей компилятивной комбинацией выразить составитель Палеи, который в таком случае может превратиться в «рупор» взглядов изучающего его автора. А задача как раз заключается в том, чтобы не «заглушить голос» самого составителя, а проследить религиозно-философскую специфику использованных при составлении труда источников и оценить авторскую их интерпретацию. Хочется надеяться, что ни по отношению к Палее, ни по отношению к другим памятникам, идейно-философская специфика не будет игнорироваться исследователями. Задачи комплексного анализа не могут быть ограничены исключением того, что составляет сущностную основу произведения с его духовным ядром, связывающим узлами смысла весь многосоставный текст.

Остается рассмотреть еще одну проблему, имеющую отношение к интерпретации палейных текстов. Из уст Е.Г. Водолазкина прозвучало утверждение, что прежде рассматривавшиеся в качестве палейных редакций тексты ныне современной наукой принимаются за самостоятельные произведения [50, с. 2]. За этой категоричностью все же нет однозначности. Ведь и сам автор критикует А.А. Алексеева за то, что тот предпочитает вести речь о редакциях, а не о разных произведениях [46, с. 335]. А.А. Алексеев воспроизводит восходящую к Истрину традицию разделения на редакции, хотя одновременно называет вторую и третью редакции собственными названиями произведений. Подобную чересполосицу можно наблюдать во многих публикациях последних десятилетий. Определенные основания для предложенных дефиниций, действительно, имеются.

18 Примеры упрощенной интерпретации памятника здесь опускаются. 
Если ТП, ПХП и КХП - это отдельные памятники, то каковы критерии для их разграничения? Для Водолазкина таковыми являются состав и жанровые отличия. Но даже с этой точки зрения многое будет зависеть от того, считается ли Палея добавлением в хронограф, или она рассматривается как основа для распространения (либо сокращения) хронографического повествования. В пределах общей коренной основы вполне позволительно говорить о редакционных отличиях, что, собственно, и фиксируется историографией. Если после расширения за счет жанрово инородных добавлений Палея остается Палеей и точкой отсчета, то она вполне может расцениваться как объект редакционных новообразования. В составе хронографа она не утрачивает признаков целостности, как случилось с «Шестодневом», включенным в ТП. К тому же и в жанровом отношении сама ТП неоднородна. Нельзя не согласится с А.А. Алексеевым, что как в хронографе встречаются толкования, так и хронологический принцип размещения материала сближает Палею с хронографом, поэтому «движение Палеи в сторону хронографии заложено в самой ее природе, начинается оно вскоре после ее создания и дает свой результат в виде соответствующей переработки текста» [3, с. 25]. По четкому обобщению сути дела О.В. Твороговым, ПХП и КХП представляют собой переработку ТП, сочетающую черты Палеи и хронографа [189, c. 161]. Признаки редакционных отличий не мешают говорить о том, что они присущи отдельным произведениям.

Двойственность при переходе редакции к новому произведению хорошо демонстрирует Палея из списка Барс. № 619. Хотя она и обладает признаками ХП, но не распространена за счет присоединения хронографических дополнений и представляет собой бесспорную редакционную правку в направлении создания ХП. Ясно, что именно Палея являлась здесь ядром для развития. А вот КХП решала уже иную задачу - задачу создание жанрово единообразного текста на хронологической основе. Там сокращенная Палея становится частью вполне самостоятельного произведения. Но и в этой переделке сохраняются признаки толковой основы. ПХП, будучи «кентавром», является компромиссом в жанровом понимании, поэтому и оценки могут быть двоякими. Думаю, что как дореволюционные, так и современные исследователи, ощущали эту двойственность. Поэтому в недавних работах речь могла идти то о произведении, то о редакции. 
Все зависело от угла зрения. Жесткая унификация эту тонкую, но существенную разницу стирает. Абсолютизация ограничивает возможности для сравнения «разведенных» текстов. Может быть, в данном вопросе и не нужно проявлять такой строгости и просто говорить о палейных типах. Ведь из истории бытования палейного текста ни ПХП, ни КХП исключить невозможно, как к тому подводит логика отказа от редакторских отличий в пользу самостоятельных произведений. Ничто не мешает рассматривать и именовать палейные тексты двояко, не впадая в противоречие.

Подытоживая сказанное, можно констатировать, что на сегодня Е.Г. Водолазкин - это единственный из новейших авторов, кто занимается изучением палейных текстов системно и выстраивает свои соображения в концептуальном ключе.

Зафиксировав панораму общих оценок Палеи, можно переходить к рассмотрению историографии конкретных проблем палеистики. На этом поле сходятся представители разных специальностей.

Приступая к обзору изучения богатейшего и разнообразного содержания Палеи представителями разных областей знания, сразу нужно сказать, что интенсивность исследований в советское время, по сравнению с дореволюционным периодом, заметно снизилась. Это не значит, что на Палею перестали обращать внимание совсем. Она просто перестала быть объектом целенаправленного предметного изучения. Но парадокс состоит в том, что Палею невозможно обойти вниманием при исследовании древнерусского книжного наследия. Поэтому работы на палейных материалах велись, и сегодня можно уже говорить о тенденциях, которые характерны для современной палеистики.

Общую картину можно представить следующим образом. У послереволюционной палейной историографии есть одна заметная особенность. Богатейшее проблемное поле Палеи в советское время изучалось крайне неравномерно. Ученые обращались к памятнику все больше попутно и эпизодично. Работы эти не отличались ни интенсивностью, ни широтой охвата многогранной палейной тематики, а в поле зрения оказывались отдельные частные аспекты. Каким-то аспектам уделялось большее внимание, а какие-то оставались в забвении. На фоне предшествующих успехов текстологов и филологов достижения представителей других дисциплин в деле изучения ТП 
выглядят гораздо более скромными, даже несмотря на то, что список обращений к Палее довольно внушителен.

Наибольший вклад в дело изучения ТП внесли представители филологической науки, хотя в исследованиях постреволюционного периода центр тяжести заметно сместился с текстологического интереса на литературоведческий. Наряду с другими произведениями древнерусской словесности Палея включается некоторыми авторами в контекст общего очерка развития древнерусской литературы, где она рассматривается либо как особая разновидность жанрового повествования [132, с. 50, 54, 112], либо со стороны присущего палейным спискам апокрифического компонента $[126$, с. $36,158,170,175 ; 130$, с. 9, 23-25; 72, с. 31, 33, 43, 44]. К общим характеристикам памятника можно отнести и такие работы, в которых Палея ставилась в один ряд с другими ключевыми произведениями отечественной книжной культуры и рассматривалась с точки зрения влияния на формирование русской духовности [179].

Некоторые филологи затрагивали проблему общих и отличительных черт Палеи в сравнении с другими произведениями древнерусской книжности. Например, А.Н. Робинсон к литературной специфике палейного текста относил присущую произведению символизацию при описании картины мира. Высказывались и оценки относительно содержания памятника в целом. По мнению Робинсона Палея формулировала догматические представления о мире с признаками универсальности, поэтому ее текст одновременно удовлетворял богословским, познавательным и эстетическим запросам древнерусского человека [181, с. 184-185].

На материалах ТП, в зависимости от конкретных интересов исследователей и направления их работ, изучалась разнообразная проблематика. Например, с привлечением палейных данных характеризуется изображение природы и человека, исследуемое на уровне художественной образности, но с выходом на мировоззренческие особенности литературного творчества $[212$, с. $131 ; 73$, с. 91]. В качестве одного из главных источников ТП привлекают при анализе книжных описаний мифических и реальных животных. В них показано, что свойственное христианству символическое осмысление представителей живого мира во многом опирается на палейные тексты $[14$, c. $80 ; 15$, c. $3-6 ; 57$, с. $145-153]$. 
Ряд работ современных филологов посвящен сюжетным и текстовым отношениям Палеи с другими литературными памятниками [45; 51; 69; 201]. При изучении непалейных сюжетов невозможно обойтись без параллелей с палейными повествованиями, а также без наблюдений над заимствованиями из ТП [56, с. 58, 61-64, 74]. Исследователи начинают уделять внимание влиянию палейных апокрифических сюжетов на фольклор [124]. Такого рода исследования ценны тем, что они обозначают реальный ареал влияния произведения, которое распространялось за пределы книжности, а отдельные палейные мотивы становились фактором массового общественного сознания.

В контексте изучения взаимоотношений ТП с другими произведениями раскрывалась их роль как важных источников сведений о мире, в первую очередь географических и естественнонаучных [30, с. 178-185; 172, с. 138-141]. Наряду с исследованием параллельных чтений некоторые авторы объектом своих исследований сделали выявление следов влияния ТП на средневековую книжность и конкретных писателей [171, с. 245-250; 133, с. 60-70].

С дореволюционных времен исследователей остро волновала проблема взаимоотношения Палеи и «Повести временных лет», которая так и не получила общепринятого решения. Этот дискуссионный вопрос не сходит со страниц научной литературы вплоть до наших дней. Сторонников разных подходов можно разделить следующим образом. Д.С. Лихачев склонялся к мнению о зависимости ТП от «Повести временных лет». Совпадения между «Речью философа» и Палеей он объяснял заимствованиями, которые составитель мог делать из летописи [131, с. 340-341]. Одновременно академик Лихачев, принимая во внимание соображения А.А. Шахматова, не исключал возможности существования у Палеи и «Повести временных лет» общего источника. Этой же точки зрения придерживался Г. Подскальски [173, с. 108-109]. О вторичности чтений Палеи к перечню народов в Начальной летописи высказывался А.Г. Кузьмин [125, с. 105].

Иную точку зрения защищает О.В. Творогов. Он обратил внимание на более подробный характер палейного текста в сравнении с летописным, что исключает влияние «Повести временных лет» на Палею [201, с. 24]. По его мнению, совпадение логичнее объяснить общим источником, каковым он считает «Хронограф по велико- 
му изложению». Поскольку библейских сведений этот хронограф не содержал, то «Речь философа», отмеченная русизмами, попала в летопись уже в готовом виде. Тем не менее окончательного заключения исследователь не делает и полагает, что для установления конкретного источника требуются специальные исследования [201, с. 27-29]. На существовании общего источника, при объяснении совпадений перечня восточноевропейских племен в летописи и в Палее, настаивает И.В. Борцова [30, с. 181-185]. Прямое палейное влияние на «Речь философа», которая рассматривается отдельно, исключает в своей статье Н.И. Милютенко. Путь поиска общего источника летописи и Палеи она считает наиболее перспективным и полагает, что при работе над «Речью философа» и ТП составители располагали компендиумом, «составленном на основе еврейских памятников ветхозаветной истории, Малого Бытия, “Иудейских древнойстей” Иосифа Флавия, с комментариями и дополнениями, выбранными из различных авторов» [152, с. 17]. Как видим, в историографии достаточно громко звучит голос, что проблема взаимоотношения между Палеей и «Повестью временных лет» не может решаться в плане простого сопоставления этих двух памятников. Мнение о том, что за обоими произведениями стоят различающиеся своим разнообразием источники можно считать едва ли не господствующим, особенно с учетом дореволюционной традиции.

В недавнем фундаментальном исследовании Т. Викул существующие гипотезы истолкования общих мест Палеи и летописи были проверены с привлечением греческих первоисточников о послепотопном расселении народов. Вопреки авторитетному заключению Истрина и Шахматова, которое поддерживалось крупными учеными в последующие годы, исследовательница пошла наперекор расхожему в историографии мнению и аргументированно отвела доводы тех, кто считал, будто составители ТП и ПВЛ пользовались общим источником. Т. Викул исходит из того, что работавший в XIII столетии составитель ТП не мог не знать летописных сводов с «Повестью временных лет», а сходство между ними, с учетом фактуры других привлекавшихся источников, свидетельствует о прямом влиянии летописи на сюжет о расселении народов [41, с. 48-50, 56-59]. Извлечение из летописи рассматривается как «каркас» для списка стран, который служил для сравнения и объяснения разных народов [41, с. 52]. С привлечением 
греческих источников доказано, что таблица народов в ТП в значительном своем объеме построена на основании «Хроники» Ипполита Римского, тогда как прежние исследователи ограничивались сопоставлениями с «Пасхальной хроникой», «Хроникой» Георгия Амартола, «Космографией» Козьмы Индикоплова. Привлеченные параллели из греческих хроник дали основание Т. Викул утверждать, что у составителя ТП не было единого источника и он пользовался компиляцией, в которой преобладала «Хроника» Ипполита Римского. Эту компиляцию, которая ранее не была известна науке, исследовательница условно называет «Компиляцией 72-х народов». Текстологическими приемами Т. Викул показала, что из этой компиляции делались извлечения и соединялись с заимствованиями из этнографического введения, принадлежавшего русскому летописцу [41, с. 58]. Поскольку первоисточники таблицы народов достаточно четко установлены, то «Хронограф по Великому изложению здесь конструкция излишняя» [41, с. 59]. Думается, что убедительная фундаментальность аргументации на много лет теперь будет предопределять трактовку рассмотренного палейного сюжета.

Современные текстологи не теряют Палею из поля зрения. Кроме подробно рассмотренных выше работ Т. Викул, А.А. Алексеева и Е.Г. Водолазкина, палейной текстологии касаются и другие исследователи, хотя и обращаются к ней прежде всего в связи с исследованием тех памятников, которые в истории своего бытования пересекались с Палеей $[131$, с. 340-341; 199, с. 20-21, 46, 58, 124, 127, 129, 133-135, 144, 187 ; 61 , с. $121-129 ; 125$, с. $103-108,126,277-279$; 129 , с. 8-11, 133-136, $152-154,200]^{19}$.

На этом фоне выделяются несколько статей Ю.А. Грибова, целиком посвященные реконструкции новгородского иллюстрированного сборника, в который входит Александро-Невский список ТП из

19 Отметим также появление работ прикладного характера, пересекающихся с палейной тематикой. К палейным материалам исследователи обращаются в контексте изучения истории русско-украинских и русско-грузинских литературных связей $[170$, с. 109-111; 139, с. 22-34; 159, с. 16-20]. Иллюстрированные списки Палеи представляют интерес для историков художественной культуры, которые исследуют миниатюры на палейные сюжеты [178, с. 97-108; 186, с. 25-29; 13, с. 25-29; 175, с. 32 -341]. Исследование изобразительного ряда палейных сюжетов началось еще в дореволюционный период [180, с. 1-9]. 
группы т. н. Коломенских списков. Палейный текст этого пергаменного кодекса распался и хранился в разных хранилищах (РНБ СПбДА А. І. 118 и РГАДА Ф. 381. Оп. 1. № 53 - т. н. Сильвесторовский сб.). Развивая идеи И.И. Срезневского и А.И. Соболевского, которые обращали внимание на принадлежности обеих частей одному кодексу [193, c. VIII-IX; 192, с. 95-96], автор установил, что соединенные части новгородского кодекса имеют общее ядро с рукописями ГИМ Увар. № 85$1^{0}$ и ГИМ Муз. № 1197, в которые наряду с «Чтением» и «Сказанием о Борисе и Глебе» входит ТП и составлявшее ее конвой лицевое «Откровение Авраама». В качестве введения к Палее в обоих рукописях стоит иллюстрированный «Шестодневец» с апокрифическими мотивами. Утраченные и перепутанные фрагменты Сильвесторовского сборника восстанавливаются на основании сравнения с Увар. № 85 и Муз. № 1197. Дефектное начало, стоявшее непосредственно перед текстом ТП, а также сюжеты иллюстраций, сопровождавшие лицевой «Шестодневец», реконструируются по аналогам из новгородских рукописей 10-20-х гг. XVI в., которые принадлежат одному писцу². С учетом параллелей можно определенно судить о составе новгородского кодекса, который, как установлено Грибовым, послужил образцом для более поздних копий ${ }^{21}$. Сопоставление рукописей позволило ему сделать вывод, что с новгородского образца заимствовались не только тексты, но и иллюстрации к ним. Ю.А. Грибов проницательно обратил внимание на то, что, в отличие от других списков Коломенского типа, Ал.-Невский и его позднейшие копии воспроизводят апокриф об Аврааме вне палейного текста, а в самом повествовании об Аврааме остается незакрытой смысловая лакуна. Эту особенность древнейшего вида ТП исправляют списки начала XV в., включающие апокрифическое повествование в историю Авраама [64, с. 34-55; 65, с. 253-267].

20 Этим же писцом была исполнена рукопись ТП из ГИМ. Вахромеевского собр. № 89. Л. 60 б -271 б [64, с. 37].

21 Порядок чтений в Увар. № 85: «Шестодневец» (Л. $16-25$ a); ТП (Л. 26 а — 296 а); «Чтение и Сказание о Борисе и Глебе»; «Откровение Авраама» (Л. 297 a 313 б); 3 Цар. 1: 1 - 11: 43 (Л. 314 - 334 б); «Суды царя Соломона» (Л. 335 а - 343 a); «Слово Козьмы Пресвитера на еретики» (Л. 343 а - 376 а, 382 а - 396 б - листы спутаны); 3 Цар. 12: 1-22: 42 (Л. 376 б - 381 б, 397 - 398 б). Конец рукописи утрачен. Состав дает представление о ядре, восходящем к новгородскому кодексу XIV в. Библейские дополнения рассматриваются как продолжение ТП [65, с. 296]. 
Апокрифический компонент, пожалуй, в наибольшей степени привлекает исследователей ${ }^{22}$. И в этом смысле современная палеистика проявляет те же тенденции, которые ей были свойственны на ранних этапах. Литературоведы продолжают традиции отечественной филологической школы и с достаточным постоянством обращаются к исследованию неканонических палейных сюжетов. Предметом исследования в последние несколько десятилетий становились как отдельные апокрифы $[219 ; 167 ; 163,21 ; 23 ; 25 ; 26 ; 29 ; 74 ; 211]$, так и конкретные апокрифические мотивы [97; 37, с. 123; 137]. Исследовались терминологические особенности палейных апокрифов [78]. Изучалось влияние палейных апокрифических сюжетов на древнерусских книжников, в частности на кирилло-белозерского книгочея Ефросина [134, с. 130-136; 97, с. 182-184; 22, с. 123-129]. Обращалось внимание на жанрово-нарративное разнообразие апокрифических памятников, входивших в жанрово-неоднозначную ТП [182, с. 19, 21]. Занимательное повествовательное начало неканонических палейных сюжетов рассматривалось как род древнерусской беллетристики [135, с. 145, $321,322,325,327-331 ; 227$, p. 35-64].

Можно говорить о качественном отличии современных исследований палейных апокрифов от работ той же тематики советского и тем более дореволюционного времени. Апокрифы и их сюжетика сами по себе уже не представляют особого интереса, они анализируются с учетом того, что являются органичными частями палейного повествования и в непосредственной увязке с конкретными редакциями Палеи. Историко-литературный контекст и текстологическое сопровождение изысканий неизменно присутствуют в трудах современных исследователей независимо от того, какие задачи ставят перед собой авторы.

22 Важным шагом в деле изучения апокрифов Палеи можно считать недавнюю публикацию подборки палейных текстов в третьем томе «Библиотеки литературы Древней Руси», который целиком посвящен неканонической книжности. Тексты воспроизводятся в оригинале по спискам ПХП, с переводом на современный русский язык, комментариями и необходимыми библиографическими справками о публикуемых памятниках [17]. Назовем также популярное издание ветхозаветных апокрифов в переводе на современный русский язык, предпринятое М.В. Рождественской, куда вошли палейные сказания о потопе, Моисее, Мельхиседеке, судах Соломона [9]. Из отдельных изданий назовем публикацию «Откровения Авраама» [222, р. 37-105] и «Сказание о Соломоне и Китоврасе» по Ефросинову сборнику Кир.-Бел. № 11/1088 [220, р. 7-11]. 
Хорошим примером может служить статья С.М. Ермоленко, в которой рассматриваются жанровые характеристики и риторические приемы «Лествицы, юже виде Иаков». Прежде всего автор выясняет, с какими названиями и в каком объеме апокриф включался в рукописи ХП и КХП, и сопоставляет эти данные с текстами «Лествицы» из списков Толкового типа [74, с. 145-146]. Для понимания символики произведения привлекаются паремийные тексты, в которых, как и в ТП, центральный образ трактуется как выражение идеи связи земного с небесным. Интересен прием разделения апокрифического сюжета на жанрово-конструктивные эпизоды, в которых дифференцируются повествовательные смыслы. Центральный для апокрифа образ лествицы в этом смысловом каркасе проявляет свой многозначный символизм: сама лествица - прообраз Христа, поднимающиеся по ней ангелы - праведники, нисходящие ангелы - беззакония народа Израиля [74, с. 146-149]. В жанровом отношении соединены: повествовательное начало, видение, обличение иудеев, пророчества, экзегеза, молитва. И все это в контексте единой повествовательной структуры, элементы которой сопоставляются по текстам разных редакций. Из сопоставления ясно, что жанровой основой является видение, а символически-семантическим ядром образ лествицы, сопряженный с обличительными, пророческими, эгзегетическими задачами произведения. По заключению автора, в основу произведения положена иносказательно-притчевая методология, толкующая скрытые смыслы [74, с. 152-153]. На примере апокрифической «Лествицы Иакова» продемонстрированы характерные черты, которые присущи Палее в целом, естественно, с учетом ее редакционных особенностей.

Возьмем другой характерный для новейшей историографии пример. Тонкие нюансы присутствуют в обычном, на первый взгляд, текстологическом анализе «Заветов двенадцати патриархов». Палейная версия этого апокрифического сочинения, казалось бы, изучена досконально. Тем не менее Е.В. Вологина вносит поправки в распространенные представления об истории бытования этого апокрифа. Полная редакция традиционно связывалась с «Архивским хронографом», а переработанная - с ТП и ХП. Автор для уточнения предлагает назвать переработанную версию толковой, а текст в ХП - восполненной толковой редакцией. Данные уточнения находятся еще в рамках традиционного подхода. Новое в другом. Опираясь на обна- 
руженную полную версию апокрифа в списке РГБ Тр. № 730, автор по характерным разночтениям находит основания для того, чтобы связать восполнение толковой версии со списком хронографа из Тр. № 730, который ближе греческому хронографу [53, с. 174]. Таким образом, уточняется история бытования апокрифа, а вместе с ней и детали эволюции палейной традиции.

В публикациях последних лет становится нормой рассматривать заимствования апокрифических материалов в состав Палеи на широком историко-литературном фоне. Это хорошо видно на примере работы С.И. Хазановой, в которой ставится вопрос о бытовании апокрифов о Моисее в древнерусской письменности. Очерчивается ареал присутствия апокрифических мотивов не только в древнерусской, но - шире - в средневековой книжности с целью выявления источников неканонической палейной истории Моисея [211, с. 128-136]. С одной стороны, фиксируются отличия чтений апокрифического «Жития Моисея» в разных типах Палеи, а с другой - воспроизводится широкая панорама бытования этого сюжета в древнерусской литературе [211, с. 128-130]. Убедительных данных о межконфессиональном влиянии на содержание Палеи в данном разделе автор не обнаруживает и не исключает греческого посредничества в трансляции на Русь ветхозаветного апокрифа.

В современной историографии есть примеры комплексного подхода к анализу апокрифических повествований Палеи. С позиций максимально широкого и глубокого охвата предмета исследования подошел к интерпретации палейных апокрифов К.В. Бондарь, диссертация и цикл работ которого посвящены повестям о Соломоне [18-29]. Сюжеты рассматриваются им с учетом специфики воспроизведения в разных рукописях, а также с учетом полноты отражения Соломонова цикла в разных списках Палеи. Апокрифы анализируются разносторонне: с позиции археографии, текстологии, литературоведения, межкультурных связей и идейной специфики. С одной стороны, детализируется история текстов, их появление и бытование в Древней Руси, а с другой - проводится всесторонний внутренний анализ содержания: характеризуются поэтика и мотивы, образность, стилистические особенности с учетом редакторской работы над текстами. Апокрифический материал исследуется не только в широком палейном, но и в общекультурном контексте эпохи. 
К.В. Бондарь, сопоставив между собой все списки с апокрифами Соломонова цикла, приходит к абсолютно обоснованному выводу, что история рукописного бытования повестей о Соломоне начинается одновременно с историей жанра ПХП. Рассматривается также появление апокрифов Соломонова цикла в некоторых рукописях не хронографического типа, а также особая редакция, которую составил древнерусский книжник Ефросин. Текстологическими средствами фиксируется появление апокрифов Соломонова цикла на стыке Толковой и Хронографической палей. Для сравнения с палейными текстами привлекаются сборники смешанного состава. Делается важный вывод, что большинство списков представляют одну редакцию и только для отдельных новелл, с учетом распространений и вставок, можно говорить о редакциях. Последнее, по заключению автора, происходит в результате редакционной правки и беллетризации повествования, с обрастанием деталями. Важны для понимания проблем палеистики наблюдения над окружением цикла. В общем и целом проделана большая работа и выбран список для научного издания (ГИМ Барс. № 619). Этот древнейший из текстов цикла, по заключению автора, подвергся наименьшей правке и модернизации [28, с. $45-46 ; 26$, с. $88-93 ; 27 ; 20 ; 24$, с. $42-87]$.

С целью поиска источников древнерусских апокрифических рассказов о Соломоне К.В. Бондарь сопоставляет апокрифический цикл с аналогичными сюжетами в еврейской литературе. Он приводит доказательства, что еврейские тексты оказались на древнерусской почве, были переведены здесь, а затем заинтересовали одного из редакторов Палеи. Бондарь отвергает гипотезу о греческом посредничестве между ветхозаветными апокрифами и Палеей. Средствами компаративистики он показывает, что источники повестей о Соломоне уходят в Вавилонскую агаду. По его заключению, первоисточником палейного апокрифического цикла о Соломоне является Вавилонский Талмуд и произведения законоучителей Палестины V-VIII вв. [19, с. 136-144; 23, с. 14-15]. С влиянием еврейской литературы связывается также сложный образ Китовраса, хотя черты этого талмудического демона испытали на себе иранское влияние [22, с. 123-129; 29, с. 111-114].

Как можно видеть, изучение ветхозаветных апокрифов непосредственным образом выводит на проблему русско-еврейских литературных связей. На зависимость ТП от иудейских памятников обращали 
внимание представители дореволюционной науки: И.Я. Порфирьев [176, с. 19-197, 232-247, 256-284], Н.С. Тихонравов [204, с. 156-177] и А.Н. Веселовский [40, с. 298-300; 39, с. 1-8]. Включение в антииудейский полемический трактат текстов еврейского происхождения отмечал также классик палеистики В.М. Истрин [92, с. 213-224]. Вопросов палейной гебраистики в контексте изучения более широкого присутствия переводов с еврейского в древнерусской книжности касались Н.А. Мещерский, В.Н. Топоров и О.В. Творогов и некоторые другие исследователи [141, с. 271-272, 298-299; 206, с. 355-356; 200, с. 46-54]. В орбиту изучения древнерусско-еврейских культурных связей входят исследования, в которых анализируется иудейское происхождение палейных «Заветов двенадцати патриархов» [16, с. 5-12; 190, с. 48-55]. В их работах суммировались как уже прежде отмечавшиеся исследователями факты, так и новые лингвистические доводы в пользу еврейского литературного влияния на Палею. Есть исследования, в которых почти все внимание фокусируется на иудейских источниках апокрифических повествований и лишь эпизодически затрагиваются параллели в древнерусской литературе [162, с. 9-10, $51-53,72-74,99-122]$.

В 2016 г. вышла насыщенная лингвистическими примерами и филологической аргументацией работа Б.А. Успенского, посвященная толкованию именования Бога в «Откровении Авраама» - ветхозаветном апокрифе, который сохранился только в славянской версии благодаря включению данного произведения в палейную компиляцию. Автор оперирует материалами семнадцати палейных списков. При этом он рассматривает как те рукописи, где «Откровение Авраама» было присоединено к палейному тексту, как в Сильвесторовском сборнике, так и случаи включения апокрифа непосредственно в палейную историю Авраама. Примеры заимствуются как из Толковой, так и Хронографической редакций Палеи, а промежуточный тип вообще не выделяется. Б.А. Успенский объясняет наличие в славянском тексте апокрифа семитизмов тем, что еврейские книжники, жившие на Руси, сверяли христианское Пятикнижие с еврейской Торой и арамейским Торгумом и воспроизводили в кириллической транскрипции еврейские формы. Данную традицию какой-то еврейский книжник перенес в апокрифический текст при воспроизведении «элъ» через э оборотное. Правда исследователь не исключает, что в данном 
случае текст мог восходить к глаголическому оригиналу, в котором глаголическая буква «есть» в недошедшем до нас славянском оригинале имела сходные начертания и сохранилась при передачи сакрального имени «элъ» [208, с. 49-86]. В общем и целом, в работе ставится важный вопрос о том, что следы еврейского влияния несут на себе не только переводы палейных апокрифических сюжетов, но и позднейшие их списки. Если исследователь прав, то славянские переводы с еврейского ветхозаветных апокрифов можно рассматривать как произведения, находившиеся в кругу чтения проживавших в древнерусских княжествах средневековых еврейских книжников.

Текстовые блоки еврейского происхождения и отдельные гебраизмы в составе палейных списков в последние годы стали объектом целенаправленного изучения А.А. Алексеевым, К.В. Бондарем и А.И. Грищенко [5; 19; 67; 69]. Поскольку работам К.В. Бондаря уделено достаточно внимания выше, остановимся подробнее на рассмотрении исследовательских подходов и наблюдений остальных авторов.

Сразу надо сказать, что А.А. Алексеев в своих построениях исходит из собственной концепции понимания истории развития палейных редакций. Как уже говорилось, древнейшую редакцию, согласно его классификации, представляет насыщенный апокрифическими повествованиями список ГИМ Барс. № 619. Такое же количество апокрифов входит в состав ХП. Но А.А. Алексеев настаивает на том, что апокрифы изначально были составной частью древнейшей редакции, и это дает ему основание считать апокрифический компонент исходным в составе ТП. Дальнейшая история текста связывается исследователем с исключением апокрифов из Палеи, что, по его мнению, отразили списки Коломенской группы, или второй редакции, по схеме Алексеева. Присутствие апокрифов в третьей редакции, или в ХП, оставлено без объяснения. В этих рамках воссоздается картина палейной гебраистики.

С влиянием семитоязычной письменности иудаизма Алексеевым связывается палейная история Моисея, насыщенная апокрифическими подробностями. В языке исследователь усматривает сохранившиеся архаизмы, которые свидетельствую о раннем переводе повествования о Моисее на славянский язык, а сохраненная гебраизированная форма при передаче имен оценивается как указание 
на еврейский источник. В установлении конкретного оригинала для перевода А.А. Алексеев ссылается на мнения своих предшественников. Еще А.И. Порфирьев считал источником «Жития Моисея» книгу Яшар [176, с. 55]. Э. Турдяну возводил этот текст к «Хронике Иерахмееля» [227, р. 35-64], но поскольку «Хроника» датируется временем не ранее XII столетия, то А.А. Алексеев солидаризируется с М. Таубе и возводит апокрифическую житийную историю Моисея к неустановленному пока еврейскому оригиналу X-XI вв. [2, с. 44-47; ср.: 224, p. 93-114] $]^{23}$.

Соломонов цикл палейных апокрифов рассматривается А.А. Алексеевым как вполне самостоятельный блок, для которого характерно единство языка и стиля. Весь цикл делится им на ряд новелл, для которых устанавливаются их источники. Параллели, согласно исследователю, следующие: сюжету поимки Китовраса (евр. Асмодей) с помощью винного колодца находится соответствие в Вавилонском талмуде; новелла, характеризующая нрав Китовраса, имеет своим источником трактат Гиттин из того же Вавилонского талмуда; история с добыванием шыниял (алмаза, для обработки камня) вместе с другими сюжетами о Китоврасе также извлечена из трактата Гиттин. Кроме сохранения гебраизма шдния отмечен неверный перевод с еврейского, где «полевой петух» (глухарь) искажен и фигурирует в древнерусском тексте как А'тььский көкот [2, с. 47-48].

Суды Соломона так же возводятся к иудейским источникам, на что впервые указывал еще Н.А. Мещерский [141, с. 298]. Суд над двухголовым человеком сопоставляется с аналогичным сюжетом в малых

23 Рассмотренная здесь интерпретация «Жития Моисея» не является единственной в историографии. Несколько иного мнения придерживается С.И. Хазанова. Чтобы определить происхождение и источники апокрифического сюжета, она привлекает для сравнения его аналоги в греческой и еврейской литературе [211, с. 131-133]. Отталкиваясь от наблюдений специалистов над характером русско-еврейских литературных связей, автор приходит к выводу, что еврейский по своему происхождению текст «Жития Моисея» необязательно мог попасть в Палею непосредственно из перевода с еврейского. Гебраизмы могли приходить и через греческие тексты. Хотя точные пути проникновения апокрифа в древнерусскую книжность не установлены, логично предполагать наличие византийского посредничества [211, с. 134-135]. Если это верно, то формирование состава ветхозаветных апокрифов шло разными путями: как через Визанетию, так и через прямые контакты с еврейской средой. 
мидрашах вавилонской экзегетической традиции. Другие сюжеты также сопоставляются с соответствующими текстами в мидрашах, хотя для некоторых новелл параллелей так и не было обнаружено. В лексике Судов указывается на присутствие гебраизмов. Например, царица Савская там именуется нєлкатошвд, а это прямая транслитерация еврейского «царица Савы». В новелле об испытании коварной жены обозначение деревянного меча как пюүданъ связывается с особенностями передачи еврейского «свинцовый меч», где в оригинале использовались одни согласные (prt), что и было воспроизведено в славянской версии по созвучию и смыслу [6, с. 67-69; 2, с. 49-51].

В общем и целом, в палейных апокрифах Соломонова цикла исследователем выявлен устойчивый ряд текстовых и смысловых гебраизмов, в славянской передаче которых присутствуют западнорусские языковые элементы. А.А. Алексеев не считает, что апокрифы переводили специально для Палеи. По его представлениям, составитель воспользовался готовым материалом, который был поставлен на службу истолкования библейских текстов. Поскольку не все оригиналы иудейских новелл выявлены и не известно существование подобного блока в отдельном виде, создание цикла предлагается относить на счет переводчика, который комбинировал имевшиеся в его распоряжении тексты. Дальнейший ход суждений следующий. Мидрашами к Вавилонскому талмуду мог располагать только просвещенный иудейский книжник. Особенностью Вавилонского талмуда, который стал известен в Европе с Х в., было обильное включение агадического материала (занимательных притч) [2, с. 5-53]. Благодаря переводу с еврейского в древнерусскую письменность из этого первоисточника проникли сюжеты о священной истории, «которые содержали занимательный материал <..>, они тоже способствовали христианскому просвещению, как его понимали в то время, путем вытеснения языческого фольклора библейскими апокрифами» [2, с. 54]. Исходя из общего понимания взаимоотношения палейных редакций, Алексеев полагает, что околобиблейский материал легендарного характера не устраивал строгих ортодоксов и был удален из ТП. Сокращение переводов с еврейского, от которых в списках Коломенской группы остались слабые следы, и антииудейские выпады, по убеждению исследователя, являются двумя взаимосвязанными частями одного замысла [4, с. 350]. Так, наблюдение за гебраизмами и иудейскими источниками ветхоза- 
ветных апокрифов было соединено с одной из концепций бытования палейных текстов на Руси. Об аргументах, оспаривающих эту концепцию, сказано выше. Впрочем, критика в отношении схемы соотношения редакций не отменяет ценных выводов о значительном влиянии на Палею иудейских источников. Основные позиции А.А. Алексеева по вопросам трактовки еврейского влияния на Палею разделяют другие исследователи, занимавшиеся той же проблематикой.

Ответ на вопрос, как и когда древнерусская книжность могла прийти в соприкосновение с ее иудейскими источниками, попытался дать в весьма дерзкой гипотезе московский лингвист А.И. Грищенко. Он исходит из того, что индикатором этого соприкосновения была ТП. Последнюю он рассматривает как «фундаментальный богословско-научный трактат» и как «энциклопедию древнерусской книжности, которая композиционно выстроена в виде комментария к Ветхому Завету» [228]. Исследователь строит свою гипотезу на том, что на юго-восточных рубежах Руси «существовала зона постоянного мессианского напряжения», а точнее территория бывшей Хазарии, которая с точки зрения хазарско-иудейского мифа является местом пребывания затерянного колена израилева. На этой основе, по мнению исследователя, в Крыму мог сложиться докараимский субстрат с признаками «одичавшего» в среде иудео-хазар иудаизма. Аналогичная секта с пережитками язычества и дуалистических воззрений могла существовать в Киеве. Этот синтез, по его предположению, позднее проявился в крымском караимстве. Существование некоего синкретического адресата предполагает и полемическая заостренность ТП, в которой антииудейские обличения соединены с критикой язычества и развитием антидуалистической темы. Автор признает рискованной логику своих построений. Но, согласимся, в противном случае вокруг ТП - вакуум.

В ином ключе исполнены лингвистические работы исследователя. При интерпретации реальных гебраизмов реальных памятников древнерусской письменности А.И. Грищенко оперирует обширной фактурой и под свои наблюдения подводит солидную доказательную базу. Статьи посвящены выяснению языковых критериев для выделения симетизмов в славяно-русских текстах. Целый ряд статей написан на материалах ТП, и в них исследователь, что характерно, переходит с лингвистического уровня на смысловой. Это особенно ценно для 
понимания палейного содержания и общего представления о Палее как о памятнике письменности, языка и мысли.

В одной из недавних статей исследователь обращается к гебра-

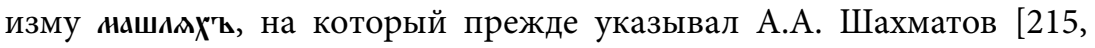
с. 217]. В отличие от предшественника, ограничившегося простой констатацией факта, А.И. Грищенко рассматривает проблему более широко. Трижды употребленный в ТП при изложении Данова пророчества гебраизм в значении «помазанник», он уверенно возводит к древнееврейской форме, попавшей в палейный текст без греческого посредничества. Исследователь показывает, что в данном случае характерным признаком является присутствие в слове буквы ш (по

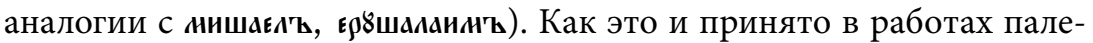
истов последних десятилетий, он прослеживает написание лексемы в разных типах Палеи и констатирует устойчивое его воспроизведение. Прослежена трансформация исконной и древней формы нашығхъ в

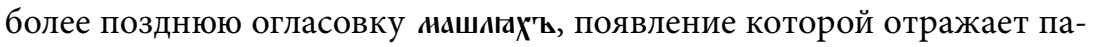
дение напряженных редуцированных. При этом хронологию трансформации формы, от установления которой зависят и датирующие признаки ТП, автор не предлагает до тех пор, пока не появятся новые достоверные данные на этот счет [67, с. 15-21].

В другой своей статье А.И. Грищенко объясняет загадку названия славяно-русской книги Кааф, которое иногда связывалось с непонятным еврейским источником. Он обращается к материалам ТП, где с таким именем фигурирует второй сын Левия из «Заветов двенадцати патриархов». Это тем более выглядит интригующе, что книга Кааф в расширенном ее именовании приписывается Палее, а на деле представляет собой толкования Феодорита Киррского на Пятикнижие Моисея [69, с. 95-97]. Исследователь изящно выстраивает обзор чтений этой лексемы на примере разных текстов и показывает, что славянский книжник не опознал в этом слове библейского героя и использовал ономастикон для именования сборника. А причина в том, что это слово в толкованиях «жидовского языка» воспринимали в значении «сборник» [69, с. 97-98]. Уже по сложившейся традиции автор рассматривает тексты заветов Левия, вошедшие в разные редакции Палеи, а также отдельные от Палеи тексты, в которых употреблялся анализируемый ономастикон. Не без иронии делается вывод, что слово, которым надписывались древнерусские сборники, могло 
пополнить ряды гебраизмов и как важно для правильного понимания этимологической метаморфозы учитывать сведения, которые дает ТП.

Остается сказать еще об одной проблеме, которую А.И. Грищенко исследовал с привлечением материала ТП. Основываясь на палейных текстах, он рассматривал оттенки оценочного употребления разных вариантов одного этнонима, обозначающих главных для составителя Палеи врагов христианства. По заключению исследователя, в синонимическом ряду жидове - июдеи - евреи первое из трех этноименований употреблялось преимущественно в негативном аспекте [66; 68]. Это наглядный пример того, как основной антииудейский полемический пафос ТП получал в дополнении к идейному звучанию еще и специфическое лексическое выражение.

Тема гебраизмов в палеистике вплотную подвела к более полному рассмотрению проводившихся лингвистических исследований ТП. Но прежде надо сказать несколько заключительных слов о присутствии иудейских литературных мотивов в антииудейском по своей полемической направленности произведении. Совершенно очевидно, что памятник отразил взаимодействие некомплиментарных друг другу этнокультурных компонентов. Это, пожалуй, самая специфическая и даже парадоксальная черта памятника. Заимствования из иудейской книжности строились по принципу освоения-отторжения конфессионально чуждых влияний. Поэтому палейные тексты, которые являются фактом отечественного литературного процесса, исследователи вынуждены анализировать с учетом межконфессиональных и межэтнических культурных связей.

В деле лингвистического анализа ТП имеет больное значение тот факт, что лексика памятника расписана в словарях («Материалы для словаря древнерусского языка»; «Словарь русского языка XI-XVII веков»). Поэтому палейный лексический материал с достаточным постоянством фигурирует в работах современных лингвистов (В.В. Колесова, В.Б. Крысько, Е.М. Верещагина и др.). К сожалению, из языковедов, которые решают свои задачи, целенаправленно к проблематике собственно палейных текстов обращаются немногие, да и те в более широком контексте сопоставления с другими произведениями [136].

На этом фоне хочется выделить блестящую работу Г.С. Баранковой, которая посвящена взаимоотношениям двух выдающихся па- 
мятников славяно-русской книжности: «Шестоднева» Иоанна экзарха Болгарского и «Толковой Палеи» (именно взаимоотношениям, ибо рассматриваются не только заимствования из «Шестоднева» в Палею, но и следы палейного влияния на поздние списки «Шестоднева», в которых писцы указывали параллельные с ТП места) [11]. Цель работы - средствами сопоставительного анализа продемонстрировать методы работы составителя ТП над своим грандиозным трудом, одним из источников которого был «Шестоднев». Можно сказать, что Г.С. Баранкова предвосхитила работу Т. Славовой по выявлению фрагментов «Шестоднева» в ТП и не ограничилась только указанием параллелей, а вывела фактуру на широкое поле историко-лексических заключений. Подобного рода наблюдения весьма важны как для понимания природы памятника с объемными компилятивными частями, так и для изучения истории текста. Своим предшественником Г.С. Баранкова считает А. Карнеева, который исследовал взаимоотношения статьи о природе в «Златой Матице» и «Шестоднева» и при этом обратил внимание на совпадения «Шестоднева» с ТП [101]. В работе на убедительных примерах показано, что текст ТП в целом ряде сюжетов зависел от «Шестоднева», причем составитель Палеи наряду с цитированием довольно свободно пересказывал пассажи Шестоднева и при этом оперировал как авторскими, так и компилятивными частями своего первоисточника. Исследовательница делает вывод, что текст «Шестоднева», сохранившийся в ТП, наиболее близок чтениям Чудовской, Уваровско-Плигинской и Егоровской ветвей списков сочинения Иоанна экзарха. Очень важен вывод, что общие чтения в наиболее исправном виде, относятся отнюдь не к Коломенскому списку ТП, который в этой части оказался наиболее дефектным по сравнению с другими списками его группы. Г.С. Баранкова обращает внимание, что сопоставление терминологической лексики дает интересный материал для лексикографа и лексиколога (это касается астрономических терминов, единиц счета времени, т. е. тематической лексики тех разделов, которые в наибольшей мере зависимы от болгарского первоисточника). Кроме того, проведенный анализ позволил установить, что зафиксированные в словарях по ТП и «Златой матице» слова, на самом деле восходят к «Шестодневу». Проведение такого рода сопоставительного текстологического анализа позволяет установить время древнейшей фиксации слов и уточнить их семантику [11, с. 276-277]. Все вместе 
дает основание говорить об усвоении лексики древнерусскими книжниками, но для боле широких обобщений нужны боле широкие изыскания. Будем ожидать продолжение подобной работы.

Группа специалистов-лингвистов, которые выбрали объектом своего исследования ТП, немногочисленна. Но тем не менее можно говорить, что костяк лингвистов-палеистов постепенно складывается.

Много внимание языковым особенностям ТП уделяют болгарские исследователи. В плане сопоставления важны наблюдения над Исторической Палеей Р.А. Станкова [196]. Подробно охарактеризовала лингвистические особенности ТП и по языковым критериям отделила авторские разделы памятника от его компилятивных частей Т. Славова [188, с. 46-58, 291-301]. В России много и плодотворно занимаются ТП А.Ю. Козлова, А.М. Камчатнов и совсем недавно пришедшая в науку Е.Н. Борюшкина.

Лингвистические наблюдения А.М. Камчатнова - первого переводчика ТП на современный русский язык - нашли отражение в ряде статей, и не случайно одна из его работ имеет подзаголовок: «Заметки на полях Толковой Палеи». В ней автор обобщает практический опыт своей деятельности как переводчика и на большом ряде примеров показывает многозначность словаря ТП. Эта многозначность, по заключению Камчатного, влечет за собой сложности в понимании памятника, ибо «анархически многозначному древнерусскому слову трудно найти соответствия в нормативном современном языке». Кажется, что единственный способ преодоления этих трудностей контекстное понимание лексических единиц. Но автор предлагает другой метод и более фундаментальный подход: составление словаря, суммирующего все греческие значения древнерусского слова и его эквиваленты в современном русском языке. Несколько блоков такого словаря и публикуется в работе. По убеждению автора, составление подобного словаря могло бы значительно облегчить работу переводчика [98]. Но это совершенно особая задача, сопряженная с изучением системных отношений в древнерусском языке, и хотелось бы надеяться, что такой энтузиаст найдется.

В другой работе А.М. Камчатнов обращает внимание на трудность перевода распространенного в Палее словоупотребления рече - формы аориста 2-3 лица единственного числа, причем затруднения касаются не семантики, а роли этого слова в предложении. Наблюдения 
над палейным текстом, в процессе его перевода, привели автора к выводу, что словоформа рече в большом количестве случаев является средством оформления чужой речи, чаще всего цитат из книг Ветхого завета. При отсутствии у древних писцов специального знака для выделения чужой речи эта словоформа заменяет кавычки, поэтому в переводе не нуждается [100].

Для тех, кто занимается ТП, полезна история расшифровки одного непонятного термина. Среди этнонимов в таблице народов, включенной в состав Палеи, названы хифоүфагон. Исследователь обратил внимание на совпадение в этой части чтений ТП с «Хроникой» Ипполита Римского. В ней упоминаются «ихтиофаги», т. е. племя рыбоедов. Сопоставление позволило распознать в этнониме $\chi^{\mathbf{\mathbf { }} ф о ү ф а г о и ~ т р а н с л и т е р а ц и ю ~ г р е ч е с к о г о ~ « и х т и о ф а г и » . ~ О р ф о г р а ф и-~}$ ческиие особенности траслитерации и анализ гапакса дали основание для предположения о возрасте фрагмента, отразившегося в составе Палеи. Этноним хьфоүфагои, как показано в статье, восходит к источнику, который не знал падения редуцированных, а это значит, что в руках составителя мог находиться образец с признаками древности, когда внутрислоговая фонема для передачи звучности была живым фактом древнерусского языка. Предварительно источник палейной компиляции в этой части предлагается датировать $\mathrm{X}-\mathrm{XI}$ вв. [100].

Остается сказать о соображениях А.М. Камчатного, касающихся принципов введения в научный оборот палейных текстов. По его убеждению, ТП не повезло. Публикация интегральной версии в свое время была вынужденной, поскольку древлехранилища тогда были не доступны для сверки текстов. Сам Камчатнов является твердым приверженцем правил публикации древнерусских текстов, которые в свое время разработала Л.П. Жуковская: полное воспроизведение оригинала с греческими параллелями и словоуказателем. Я.Н. Щапова и других историков интересовал смысл, поэтому они склонялись к упрощенному воспроизведению текстов. Этот принцип возобладал при публикации серий литературных памятников в рамках ПЛДР и БЛДР. В прежние времена, времена пишущих машинок, такой метод еще был оправдан. Теперь с помощью компьютера текст можно воспроизводить с максимальной точностью. На появление такого рода изданий и надеется исследователь [99, с. 231-237]. 
За несколько последних лет появилась серия статей Е.Н. Борюшкиной - ученицы А.М. Камчатнова. Свою кандидатскую диссертацию и связанные с ней публикации в научных сборниках молодая исследовательница посвятила исследованию отвлеченной лексики ТП. На обширном палейном материале она анализирует семантическую специфику употребления отвлеченной лексики и ее словобразовательные признаки. Борюшкина приходит к выводу, что категория отвлеченности является разновидностью абстрактной лексики, которая формировалась на основании частных семантических значений. В ее статьях описываются разнообразные словообразовательные средства для оформления отвлеченной лексики $[33 ; 34 ; 36]$. Молодая исследовательница подходит к решению проблемы с точки зрения философско-мировоззренческих оснований речевых практик и связывает отвлеченную лексику с особенностями древнерусского языкового сознания, а конкретно, увязывает абстрагирование с отражением этого процесса в лексике [35, с. 448-450].

В своих статьях Е.Н. Борюшкина показывает различия семантического употребления одних и тех же слов и в сравнении выявляет механизм отпочкования отвлеченных значений. Например, положительное в своем значении слово гордость наделяется в ТП качеством дьявольским (гордыня) и используется только в отрицательной коннотации для характеристики неприемлемого человеческого поведения [32, с. 225-230]. На этом частном примере демонстрируется один из способов формирования категории отвлеченности для обозначения нравственных понятий.

Анализ лексического абстрагирования Е.Н. Борюшкина выводит на уровень идейно-смысловой интерпретации произведения. В одной из работ речь идет о том, как средствами отвлеченной лексики в ТП выражаются базовые смыслы христианского взгляда на действительность. В частности, показано, что в оценочных характеристиках иудеев устойчиво употребляется лексема вєздакониє, тогда как понятие грtхтъ применяется при описании несовершенной человеческой природы вообще. Смягчение оценки, согласно установкам ТП, было возможно только в случае принятие иудеем крещения [31, с. 49-54]. Так средствами точного словоупотребления формировался правильный взгляд на главные нравственно-религиозные понятия, адекватное восприятие которых напрямую восходит к пониманию принци-

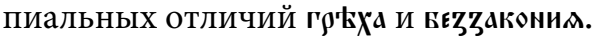


Принципиальная важность значения работ Е.Н. Борюшкиной состоит в том, что они нацеливают на выявление специфики языкового сознания книжников древнерусской эпохи и дают в руки исследователя инструмент, который способствует пониманию идейно-философского своеобразия произведения. У этих интересных и полезных во всех отношениях работ есть только один недостаток: исследовательница не принимает во внимание составной характер компилятивного памятника, а поэтому целое она характеризует по частям, которые в их первоисточниках могут отражать совсем иные литературно-текстовые реалии. И это обстоятельство несколько «замутняет» чистоту наблюдений.

Много и плодотворно лингвистическим изучением ТП занимается А.Ю. Козлова. В своих работах она анализирует языковые особенности памятника и при этом охватывает материал максимально широко - со стороны его лексических, грамматических, стилистических, почерковых и текстологических аспектов. Многогранный охват материала имеет одну общую цель: выяснение роли лингвистических факторов в истории текста, которые должны послужить средством установления времени и места создания ТП.

А.Ю. Козлова сосредоточилась, прежде всего, на исследовании Коломенской Палеи. Она обращает внимание исследовательского сообщества на то, что хотя Коломенский список (Тр. № 38) до сего дня является единственным из опубликованных палейных текстов, он по-прежнему остается неизученным всесторонне как со стороны состава, так и с точки зрения его языковых признаков. Трудно не согласиться с исследовательницей, что без знания запечатленных в воспроизводимом писцом тексте примет своего времени невозможно продуктивно изучать памятник. На обнаружение этих меток и направлены многолетние изыскания автора.

Можно без преувеличения сказать, что на сегодня А.Ю. Козлова является едва ли не единственным из специалистов, кто всецело посвятил свою научную деятельность кропотливому разбору ТП. В ее статьях отдается должное вкладу тех исследователей, которые внесли свой вклад в изучение палейной проблематики. Есть публикация, которая целиком посвящена истории соприкосновения И.И. Срезневского с палеистикой. Хотя выдающийся русский лингвист специально и не занимался этим памятником, в его научной биографии ТП заняла определенное место. И дело не только в том, что словарный состав Палеи получил отраже- 
ние в его «Материалах для словаря древнерусского языка». Срезневский первым указал на палеографические признаки, общие для древнейшего Александро-Невского списка ТП и т. н. Сильвесторовского сборника, хранящегося в РГАДА [193, с. VIII-IX]. Позднее его поддержал А.И. Соболевский [192, с. 95-96]. С тех пор в научный обиход прочно вошло представление о существовании распавшейся палейной рукописи, разделенной на части еще в древнерусскую эпоху [102, с. 152-163].

Естественно, как лингвиста Козлову интересуют прежде всего лингвистические нюансы Коломенской Палеи. Но исследовательница не ограничивается только языковой спецификой материала. Она дает в своих работах общую характеристику памятнику, который оценивает как уникальный по своему содержанию энциклопедический труд $[117$, с. $21-32 ; 121$, с. 14-15]. На этом фоне много внимания уделяется изучению лексических и грамматических особенностей Коломенского списка. Исследовательница не ограничивается только Тр. № 38, а сопоставляет разные списки внутри толкового типа. В результате выявлены устойчивые языковые особенности списков коломеннской группы [120, c. 53-56; 111, c. 180-183; 109, с. 396-398; 118, с. 64-65; 109].

Анализ лексики и грамматики не являются для А.Ю. Козловой самоцелью. Ее интересуют языковые способы выражения смысла [116, c. 83-86; 110, с. 105-117] или тайна загадочных и трудно переводимых слов [122, с. 342-357; 103, с. 75-80]. Много внимания уделено лексической характеристике философских фрагментов Палеи [106, с. 26-27; 115, 225-230]. Все это выводит на уровень фиксации присущих произведению способов передачи религиозно-философских значений и напрямую связано с реконструкцией языкового сознания составителя ТП [114].

Много внимания уделено в работах А.Ю. Козловой изучению почерков. Установлено, что Коломенский список создавался двумя писцами. Оба находились под влиянием южнорусского диалекта, а главное, в своей работе они никак не отразили влияния орфографической реформы, проводившейся в то время Киприаном [107, с. 13-19]. В создании Александро-Невского списка Палеи, по данным почерковедческой экспертизы, принимали участие три писца. Сличением почерков подтверждены доводы И.И. Срезневского и Ю.А. Грибова о единстве Сильвесторовского сборника с СПбДА А. І. 119. В старших списках толкового типа выявлены признаки, характерные для древнерусской нормы графики, при том, что следы южнославянского 
влияния имеют поверхностный характер, да и те отразились только в поздних списках. Кроме того, сделан важный для палеистики вывод: принятое в историографии отнесение Александро-Невского списка Палеи к Коломенскому типу не оправдано [105; 104, с. 189-224].

Следует отметить одно важное исследовательское качество, которое есть далеко не у всех обращавшихся к палеистике лингвистов. В своих лингвистических штудиях А.Ю. Козлова неизменно учитывает сложность состава компилятивного памятника и дифференцированно подходит к анализу составляющих его частей. Именно с учетом комбинированного характера, восходящего к разным источникам текста, удалось описать языковые признаки неоднородных текстовых блоков. В частности, установлено отсутствие слов с полногласием при цитировании библейских текстов, и, наоборот, присутствие их в качестве характерной языковой черты при воспроизведении заимствований из «Шестоднева» Иоанна экзарха Болгарского. Наряду с этим в разделах, принадлежащих составителю ТП, фиксируются ярко маркированные русизмы. При сличении чтений в списках разных веков отмечено увеличение количества полногласных вариантов в старших из них. Или другой пример: язык входящих в состав Палеи апокрифов отличен от остального текста, что оценивается как свидетельство особого их происхождения и как признак, указывающий на возможно более позднее включение неканонических сюжетов в текст [112-114].

Изучение палейных списков со стороны состава и языковых особенностей дало А.Ю. Козловой основание для корректировки существующей схемы распределения списков по редакциям. Тщательное сличение признаков позволило исследовательнице сделать вывод о полном соответствие РНБ Кир.-Бел. № 68/1145 и ГИМ Увар. № 620, которая рассматривается как представитель, промежуточного типа между толковым и хронографическими видами Палеи. Это важное уточнение, поскольку прежние исследователи относили Кирилло-Белозерский список к толковому виду. С учетом этой и некоторых других поправок составлена классификация списков по редакциям. На сегодня это наиболее точная картина, дающая представление о соотношении списков разных типов [104, с. 219-220] ${ }^{24}$.

24 Сегодня, с привлечением большого числа новых списков, выстраивается совершенно новая классификация, выводы которой будут представлены в издании «Палея Толковая расширенного состава». 
Если оценивать научный вклад в палеистику А.Ю. Козловой в целом, то можно констатировать следующее: исследовательница поставила задачу проведения широкого сравнения списков разного времени с целью наблюдения за изменением лексического состава и динамикой других языковых признаков. Начиная с 1994 г. она последовательно воплощает эту задачу в жизнь, осуществляя шаги в направлении максимально полной историко-языковой характеристики памятника. Так постепенно накапливается материал, дающий представление о взаимоотношении палейных списков и истории бытовании текста ТП в древнерусской книжности.

Обобщая имеющийся опыт оценки памятника с точки зрения его языковой специфики, можно констатировать, что специалисты-лингвисты, которые выбрали объектом своего исследования ТП, дополняя друг друга, закладывают основу для фундаментального и всестороннего осмысления языкового своеобразия сложнейшего по своему составу произведения, сплавившего в своем содержании неповторимый букет самых разных по времени и происхождению текстов.

С позиций междисциплинарного подхода к изучению ТП можно говорить о положительных тенденциях в палеистике. Если в 40-80 гг. прошлого столетия к текстам ТП обращались большей частью попутно, в связи с решением далеких от палейной тематики исследовательских задач, то на рубеже столетий вновь возрождается понимание важности текстологического анализа памятника и уже на этой основе строится исследование его многогранного содержания. За последние годы заметно повысился интерес к самому памятнику со стороны представителей разных научных дисциплин, о чем сказано выше. На фоне междисциплинарного подхода формируется устойчивая традиция исследования идейно-религиозных оснований текста и его философской специфики. Правда, это направление молодое, а его представители делают первые шаги в деле понимания важнейших признаков, определявших своеобразие текста. Палея исследуется как со стороны присущих ей религиозно-философских особенностей [216-218; 70, c. 9-14; 60, c. $178-194 ; 151$, с. $105-113 ; 150$, с. 490-501; 149 , с. $457-459 ; 148$, с. 21-31], так и с точки зрения разных аспектов философской специфики произведения (антропологического: [148, с. 21-31]; гносеологического: [60, с. 178-194]; натурфилософского: [59, с. 15-38]; космологического: [145, с. 7-23]). Параллельно с изу- 
чением религиозно-философских основ произведения сотрудниками Института философии РАН вводились в оборот антропологические, натурфилософские и космологические фрагменты ТП [71, с. 561-712; 123, с. 158-369]. Публикации осуществлялись на языке оригинала с переводом на современный русский язык. Тексты комментировались с точки зрения филологии, религиоведения и философии.

Отрадным показателем является не только заметное повышение удельного веса разнообразных многочисленных исследований памятника, но и регулярная организация научных конференций, специально посвященных междисциплинарному анализу палейного содержания. Почин был положен 22 января 2013 г., когда в Москве по инициативе А.Н. Ужанкова из разных стран собрались специалисты, чтобы обменяться опытом по исследованию богатейшего содержания ТП и обсудить перспективные направления дальнейшего исследования памятника. 24-25 ноября 2015 г. на базе МИФИ была проведена вторая международная практическая конференция «Палея Толковая в контексте древнерусской культуры XI-XVII вв.». В ближайшее время планируется проведение уже третьей конференции, посвященной изучению ТП. За весьма незначительный период существенно расширился круг участвующих в работе постоянной конференции специалистов, а сами конференции по существу стали площадкой комплексного анализа уникального произведения.

Конечно, как и в любом начинании, с репертуаром докладов и качеством выступлений не все обстояло гладко. Собственно палеисты (т. е. те, кто целенаправленно занимается изучением палеи) в числе участников были представлены единицами. Отчасти это понятно, ведь современная палеистика только начинает оформляться. Некоторые из докладчиков совсем недавно открыли для себя Палею, некоторые касались палейной тематики постольку, поскольку она соприкасалась с далекой от этой тематики научными темами исследователей. В таких докладах не всегда просматривалось знание истории изучения памятника и понимание сложности насущных проблем палеистики. По этой причине самые актуальные, спорные и нуждающиеся в специальном и углубленном исследовании темы обсуждались недостаточно широко. От конференции к конференции тем не менее качество работы симпозиумов заметно повышается. Организаторы уже ко времени проведения второй конференции осознали дефицит 
докладов по текстологической тематике и для исправления дисбаланса расширили число приглашенных специалистов как раз по этому направлению.

Можно констатировать, что участники научных конференций выработали общее для них понимание ТП как памятника с несколькими жанровыми признаками, обладающего многозначным и неоднородным содержанием. Вне зависимости от специализации исследователей Палея рассматривается как компендиум, выстроенный на синтезе богословия, философии, естествознания, как произведение установочное и ключевое для духовной жизни Древней Руси. Нельзя не отметить рост интереса к философско-мировоззренческой специфике памятника. Больше внимания стало уделяться неканоническим компонентам произведения, которое являлось своеобразной древнерусской антологией апокрифов. Особенно полезны для понимания компилятивного состава произведения выявление включенных в компилятивную композицию византийских источников, без дешифровки которых сюжеты остаются малопонятными. Каждый из специалистов с позиций своей науки входит в необъятное проблемное поле Палеи Толковой, предлагая трактовку той или иной грани неисчерпаемых смыслов произведения.

Общий обзор исследований фиксирует новые явления, происходящие в палеистике. Если в 40-80 гг. прошлого столетия к текстам ТП обращались большей частью попутно, в связи с решением далеких от палейной тематики исследовательских задач, то на рубеже столетий вновь возрождается понимание важности текстологического анализа памятника и уже на этой основе исследование его содержания.

Как совершенно справедливо констатировал А.Н. Ужанков после завершения первой конференции, в деле изучения Палеи остается еще много нерешенных вопросов [207, с. 7]. И с этим не поспоришь. В деле разрешения загадок Палеи проблем хватит не на одно поколение исследователей. А с учетом того, что в последние годы резко повысился интерес к памятнику и возросла интенсивность публикаций по палейной тематике, можно ожидать появление новых интересных работ. Уже по тем работам, которые появляются в последнее время, видно, что изучение частных и общих проблем выдающегося 
произведения древнерусской книжности с каждым годом достигает все более и более высокого профессионального уровня. Это позволяет надеяться уже на ближайшие коренные сдвиги в палеистике и на введение в оборот основных редакций ТП.

\section{СПИСОК ЛИТЕРАТУРЫ}

1 Адрианова В.П. К литературной истории Толковой Палеи. Киев: Тип. Акц. Об-ва «Петр Барский в Киеве», 1910. 77 с.

2 Алексеев А.А. Апокрифы Толковой Палеи, переведенные с еврейских оригиналов // ТОДРЛ. СПб.: Дмитрий Буланин, 2007. Т. 58. С. 41-57.

3 Алексеев А.А. Палея в системе хронографического жанра // ТОДРЛ. СПб.: Дмитрий Буланин, 2006. Т. 57. С. 25-32.

4 Алексеев А.А. Переводы Библии // История еврейского народа в России. От древности до раннего Нового времени / под ред. А. Кулика. М.; Иерусалим: Мосты культуры, Гешарим, 2010. Т. 1. С. 345-355.

5 Алексеев А.А. Переводы с древнееврейских оригиналов в Древней Руси // Russian Linguistics. 1987. Vol. XI. № 1. P. 1-20.

6 Алексеев A.A. Русско-еврейские литературные связи до XV в. // Jews and Slavs. Vol. 1 / Ed.: W. Moskovich, S. Shvarzband, A. Alekseev. Ierusalem; St. Petersburg: Nauka Publishers, 1993. C. 44-75.

7 Алексеев А.А. Текстология славянской Библии. СПб.: Дмитрий Буланин, 1999. $256 \mathrm{c}$.

8 Апокріфи і легенди з українськихъ рукописів, зібирав, упорядкував і пояснив Ів. Франко. Львів: Накладом наук. т-ва ім. Шевченка, 1896. Т. I: Апокріфи старозавітні. 512 с.

9 Апокрифы Древней Руси / сост. и предисл. М. В. Рождественской. СПб.: Амфора, 2002. 238 с.

10 Архангельский А.С. Творения отцов церкви в древнерусской письменности. Казань: Тип. Имп. Ун-та, 1889. Т. I-II. 203 с.

11 Баранкова Г.С. О взаимоотношениях «Шестоднева» Иоанна экзарха Болгарского и «Толковой Палеи» (текстолого-лингвистический аспект) // История русского языка. Исследования и тексты / отв. ред. В.Г. Демьянов, В.Ф. Дубровина. М.: Наука, 1982. С. 262-277.

12 Баранкова Г.С., Мильков В.В. Шестоднев Иоанна экзарха Болгарского / Cерия: Памятники древнерусской мысли: исследования и тексты. СПб.: Алетейя, 2001. Вып. II. 972 с.

13 Белоброва О.А. Этикетный мотив в древнерусской миниатюре XV в. // Исследования по древней и новой литературе / отв. ред. Ю.К. Герасимов. Л.: Наука, 1987. С. 25-31.

14 Белова О.В. «Быстроскочи васеръ наборъ зажей рысь...» (о «говорящих» ошибках в древнерусских сказаниях о животных) // Славянские этюды. Сб. к юбилею С.М. Толстой / отв. ред. Е.Е. Левкиевская. М.: Индрик, 1999. С. 70-85.

15 Белова О.В. Обобщающие названия животных в славянском «Физиологе» // 
Роль библейских переводов в развитии литературных языков и культуры славян. Тезисы докладов международной научной конференции (Москва, 23-24 ноября 1999 г.) / отв. ред. Л.Н. Смирнов М.: Ин-т славяноведения, 1999. C. 3-6.

16 Берсенев П.В. О чем молчит Библия // Ветхозаветные апокрифы: Книга Юбилеев; Заветы двенадцати патриархов / пер. А.В. Смирнова; сост. и коммент. П.В. Берсенева. СПб.: Амфора, 2000. С. 5-12.

17 БЛДР. СПб.: Наука, 1999. Т. 3. 544 с.

18 Бондарь К.В. Давньоруські повісті Соломонового циклу: джерела, текстологія, проблематика, поетика: автореф. ... канд. филол. наук. Харків, 2007. 19 с.

19 Бондарь К.В. К вопросу о еврейских источниках палейной «Повести о Китоврасе» // Материалы Восьмой ежегодной международной междисциплинарной конференции по иудаике. М., 2001. Ч. 2. С. 136-144.

20 Бондарь К.В. К истории текста повестей о Соломоне в Палее // Наукові записки Харківського національного педагогічного униіверситету ім. Г.С. Сковороди. Серия: Литературознавство. Харків, 2010. № 4 (64). URL: http://nbuv. gov.ua/UJRN/Nzl_2010_4.1_3 (дата обращения: 05.08.2019).

21 Бондарь К.В. Наблюдения над рукописным конвоем повестей о Соломоне // Наукові записки Харківського національного педагогічного униіверситету ім. Г.С. Сковороди. Серия: Літературознавство. Харків, 2006. Вип. 4 (48). Ч. 2. С. 164-168.

22 Бондарь К.В. «О Китоврасе от Палеи» и другие сюжеты книгописца Ефросина // Материалы Седьмой ежегодной международной междисциплинарной конференции по иудаике. М.: [Б.и.], 2000. Ч. 2. С. 123-129.

23 Бондарь К.В. Повести о Соломоне в науке о литературе // Двенадцатые международные чтения молодых ученых памяти Л.Я. Лившица. Харьков: [Б.и.], 2007. C. 14-15.

24 Бондарь К.В. Повести Соломонова цикла: из славяно-еврейского диалога культур. Харьков: Новое слово, 2011. 156 с.

25 Бондарь К.В. Рукописные данные по проблеме Соломоновых сказаний // Тирош: Труды по иудаике. М., 2005. Вып. 7. С. 88-93.

26 Бондарь К.В. Славянские Суды Соломона: источники, состав, текстология // Материалы Двенадцатой ежегодной международной междисциплинарной конференции по иудаике. М.: Ин-т славяноведения, 2005. Ч. 1. С. 352-356.

27 Бондарь К.В. Соломонов цикл по ранним спискам // IX конференция молодых ученых «Вопросы славяно-русского рукописного наследия» (к 75-летию Отдела древнерусской литературы ИРЛИ РАН). 29 сентября -2 октября 2008. СПб., 2008. URL: http://odrl.pushkinskijdom.ru/Default.aspx?tabid=7822 (дата обращения: 12.02.2019).

28 Бондарь К.В. Царь Соломон в русских рукописных сборниках // 2000 лет христианства. Проблемы истории и культуры: Материалы научн. конф. Коломна: Колом. гос. пед. ин-т, 2000. С. 45-46.

29 Бондарь К.В. Этюд об Асмодее и Китоврасе // Тирош: Труды по иудаике / отв. ред. М. Членов. М.: Judaica Rossica, 2007. Вып. 8. С. 111-114. 
30 Бориова И.В. Легендарные экскурсы о разделении земли в древнерусской литературе // Древнейшие государства на территории СССР. 1987 г. / отв. ред. А.П. Новосельцев. М.: Наука, 1989. С. 178-184.

31 Борюшкина Е.Н. «Грех» и «безаконие» в Толковой Палее // Древняя Русь. Вопросы медиевистики. 2013. № 4 (54). С. 49-54.

32 Борюшкина Е.Н. Особенности употребления слов гордость и гордыня в «Толковой Палее» // «Палея Толковая» в контексте древнерусской культуры XI-XVII вв. Материалы Первой международной научной конференции / под ред. А.Н. Ужанкова. М.: Согласие, 2014. С. 225-230.

33 Борюшкина Е.Н. Отвлеченная лексика в Толковой Палее: автореф. ... канд. филол. наук. М., 2013. 24 с.

34 Борюшкина Е.Н. Проблемы перевода слова живот, житие, жизнь в Толковой Палее // Научно-техническая информация. Сер. 2: Информационные процессы и системы. М.: ВИНИТИ, 2012. № 8. С. 25-28.

35 Борюшкина Е.Н. Специфика понятия «отвлеченная лексика» в древнерусском языке // Вестник Нижегородского университета им. Н.И. Лобачевского. 2010. № 4 (2). С. 448-450.

36 Борюшкина Е.Н. Членение семантического объема многозначного слова в древнерусском языке как проблема исторической лексикографии (на примере анализа слова «свет» в Палее Толковой) // Институт XXI век: подготовка педагогических кадров (актуальность, проблемы, перспективы). Материалы научно-практической конференции / отв. ред.: Е.Г. Чернышева, О.В. Сененко, О.Н. Шумкина. М.: МГПИ, 2009. Т. 1. Вып. 4. С. 95-97.

37 Былинин В.К. «Художество»: изображение зодчего в древнерусской литературе // Древнерусская литература: Изображение общества. М.: Наука, 1991. С. $118-154$.

38 Веревский Ф. Русская историческая Палея // Филологические записки. Воронеж, 1888. Т. 2. С. 1-18.

39 Веселовский А.Н. Заметки по литературе и народной словесности: 1. Эпизод о южной царице в Палее // СОРЯС. 1883. Т. 32, № 7. С. 1-8.

40 Веселовский А.Н. Талмудический источник одной Соломоновой легенды в русской Палее // ЖМНП. 1880. Апрель. С. 298-300.

41 Викул Т. Толковая Палея и Повесть временных лет. Сюжет о «разделении языкъ» // Ruthenica. 2007. № 6. С. 37-85.

42 Водолазкин Е.Г. Всемирная история в литературе Древней Руси (на материале хронографического и палейного повествования). Мюнхен: Sagner, 2000. $408 \mathrm{c}$.

43 Водолазкин Е.Г. Ефросиновская Палея: до и после // Russica romana. 2007. V. 14. P. 9-22.

44 Водолазкин Е.Г. Из истории древнерусского исторического повествования. Краткая Хронографическая Палея // Вспомогательные исторические дисциплины / отв. ред. В.Н. Плешков. СПб.: Дмитрий Буланин, 2007. Т. 30. С. 341-349.

45 Водолазкин Е.Г. К вопросу об арабских наименованиях планет в древнерусской книжности // ТОДРЛ. СПб.: Дмитрий Буланин, 1996. Т. 49. С. 677-683. 
46 Водолазкин Е.Г. Как создавалась Полная Хронографическая Палея. Часть 1 // ТОДРЛ. СПб.: Дмитрий Буланин, 2009. Т. 60. С. 327-353.

47 Водолазкин Е.Г. Как создавалась Полная Хронографическая Палея. Часть 2 // ТОДРЛ. СПб.: Дмитрий Буланин, 2014. Т. 62. С. 175-198.

48 Водолазкин Е.Г. Краткая Хронографическая Палея: между историографией и богословием // Вестник истории, литературы, искусства. М.: Наука, 2006. T. 2. C. $233-244$.

49 Водолазкин Е.Г. Краткая Хронографическая Палея (текст). Вып. 2 // ТОДРЛ. СПб.: Дмитрий Буланин, 2007. Т. 58. С. 341-349.

50 Водолазкин Е.Г. Новое о палеях (некоторые итоги и перспективы изучения палейных текстов) // Русская литература. 2007. № 1. С. 3-23.

51 Водолазкин Е.Г. О Толковой Палее, Златой Матице и «естественнонаучных» компиляциях // ТОДРЛ. СПб.: Дмитрий Буланин, 1999. Т. 51. С. 80-90.

52 Водолазкин Е.Г. Редакции Краткой Хронографической Палеи // ТОДРЛ. СПб.: Дмитрий Буланин, 2004. Т. 56. С. 164-180.

53 Вологина Е.3. Еще раз о текстологии «Заветов 12 патриархов» в древнерусской книжности // XLIII Международная филологическая научная конференция. 11-16 марта 2014 г. Тезисы. СПб.: СПбГУ, 2014. С. 174.

54 Востоков А.Х. Описание русских и славянских рукописей Румянцевского Музеума. СПб.: В тип. Имп. АН, 1842. 902 с.

55 Гаврюшин Н.К. Космологический трактат XV века как памятник древнерусского естествознания // Памятники науки и техники. 1981 / отв. ред. Л. Майстров. М.: Наука, 1981. С. 183-197.

56 Гадалова Г.С. К вопросу о редакциях и литературных источниках азбучных стихов об Адаме // Древняя Русь. Вопросы медиевистики. 2008. № 4. С. 58-77.

57 Гаричева Е.А. Зооморфная и растительная символика в «Толковой Палее» // «Палея Толковая» в контексте древнерусской культуры. Материалы Первой международной научной конференции / под ред. А.Н. Ужанкова. М.: Согласие, 2014. С. 135-153.

58 Герасимова И.А. Древнерусская «Палея»: толкование трудных вопросов мироздания // Дельфис. 2013. № 2. С. 64-71.

59 Герасимова И.А. «Толковая Палея», античная наука и житейский опыт // «Палея Толковая» в контексте древнерусской культуры XI-XVII вв. Материалы Первой международной научной конференции / под ред. А.Н. Ужанкова. М.: Согласие, 2014. С. 15-38.

60 Герасимова И.А., Мильков В.В. Толковая Палея о мироздании и познании // Эпистемология и философия науки. 2013. № 2 (36). С. 178-194.

61 Горина Л.В. Византийская и славянская хронография (существовал ли болгарский хронограф) // Византия. Средиземноморье. Славянский мир: Сборник к XVIII Международному конгрессу византинистов / редкол. Г.Г. Литаврин и др. М.: Изд-во МГУ, 1991. С. 121-129.

62 Горский А.В., Невоструев К.И. Описание славянских рукописей Московской синодальной библиотеки. Отд. II: Писания святых отцов. Ч. 1: Толкование Священного Писания. М.: Синод. тип., 1857. 209 с. 
63 Горский А.В., Невоструев К.И. Описание славянских рукописей Московской Синодальной библиотеки. Отд. II: Писания святых отцов. Ч. 2: Писания догматические и духовно-нравственные. М.: Синод. тип., 1859. 705 с.

64 Грибов Ю.А. Значение палеографических особенностей для определения состава и генеалогии четьих сборников // История и палеография / отв. ред. В.И. Буганов. М.: ИРИ РАН, 1993. Т. 1. С. 34-49.

65 Грибов Ю.А. О реконструкции новгородского иллюстрированного сборника XIV в. // Хризограф. М.: Сканрус, 2009. Вып. 3: Средневековые книжные центры: местные традиции и межрегиональные связи / сост. Э.Н. Добрынина. С. 253-267.

66 Грищенко А.И. Наименование евреев в древнерусских антииудейских сочинениях: к истории экспрессивности этнонима жидове // Научные труды по иудаике. Материалы XVIII Международной ежегодной конференции по иудаике / отв. ред. В.В. Мочалова. М.: Сэфер, 2011. Т. 1. С. 189-204.

67 Грищенко А.И. О гебраизме машляхъ 'Messias' в Палее Толковой // Вестник Литературного института им. А.М. Горького. М.: Изд-во Литературного института A.М. Горького, 2012. № 1 (Hermeneumata: Сб. научн. трудов к 60-летию д. филол. н., проф. А.М. Камчатнова). С. 15-21.

68 Грищенко А.И. Об экспрессивности этнонима жидове в древнерусской книжности (на материале Палеи Толковой) // Слов'янський збирник. 36. наук. праць. Одеса: Одеський національний ун-т ім. I.I. Мечникова, 2011. Вип. XIV-XV. С. 94-102.

69 Грищенко А.И. Славянские приключения греческого Кеггата: О происхождении названия древнерусской «Книги Кааф»// Slověne. 2012. Т. 1, № 2. С. 95-100.

70 Громов М.Н. Философское значение «Толковой Палеи» // «Палея Толковая» в контексте древнерусской культуры XI-XVII вв. Материалы Первой международной научной конференции / под ред. А.Н. Ужанкова. М.: Согласие, 2014. C. 9-14.

71 Громов М.Н., Мильков В.В. Идейные течения древнерусской мысли. СПб.: Изд-во РХГУ, 2001. 960 с.

72 Гудзий Н.К. История древней русской литературы. Изд. 7-е. М.: Просвещение, 1966. 542 с.

73 Демин А.С. Древнерусская литературная анималистика // Древнерусская литература: Изображение природы и человека / отв. ред. А.С. Демин. М.: Наследие, 1995. С. 89-126.

74 Ермоленко С.М. Апокрифическое сказание «О лествице, юже виде Иаков» в составе Толковой Палеи: система риторических приемов, жанровые характеристики // Вестник Новосибирского государственного университета. Ceрия: история, филология. 2012. Т. 11, № 12. С. 145-154.

75 Жданов И.Н. Палея // Сочинения. СПб., 1904. Т. 1. 871 с.

76 Жданов Р.В. Крещение Руси и Начальная летопись // Исторические записки. 1939. № 5. С. 3-30. 
77 Заболотский П. К вопросу об иноземных письменных источниках «начальной летописи» // Русский филологический вестник. Варшава, 1901. T. XLV, № 1-2. С. 4-19.

78 Завадская C.B. Наблюдения над терминологией ветхозаветного сюжета о Моисее (по поводу соотношения ранних летописных и палейных текстов) // Восточная Европа в древности и Средневековье. Спорные проблемы истории. Чтения памяти В.Т. Пашуто (Москва, 12-14 апр. 1993 г.): Тез. докл. / отв. ред. А.П. Новосельцев. М.: Ин-т рос. истории, 1993. C. $28-31$.

79 Истомин К.К. К вопросу о редакциях Толковой палеи // ИОРЯС. 1905. Т. 10. Кн. 1. С. 147-184.

80 Истомин К.К. К вопросу о редакциях Толковой палеи // ИОРЯС. 1906. Т. 11. Кн. 1. С. 337-374.

81 Истомин К.К. К вопросу о редакциях Толковой палеи // ИОРЯС. 1909. Т. 13. Кн. 4. С. 290-343.

82 Истомин К.К. К вопросу о редакциях Толковой палеи // ИОРЯС. 1913. Т. 18. Кн. 1. С. 87-172.

83 Истрин В.М. Взаимоотношение полной и краткой Палей в пределах текста Палеи Коломенской. Общие выводы. Таблицы // ИОРЯС. 1906. Т. ХІ. Кн. 3. С. $418-450$.

84 Истрин В.М. Замечания о составе Толковой Палеи // ИОРЯС. 1897. Т. II. Кн. 1. С. 175-209.

85 Истрин В.M. Замечание о составе Толковой Палеи. Гл. IV: Книга Кааф // ИОРЯС. 1897. Т. ІІ. Кн. 4. С. 845-905.

86 Истрин В.М. Замечания о составе Толковой Палеи. Гл. V-XI: Златая Матица. Византийские прототипы Толковой Палеи // ИОРЯС. 1898. Т. III. Кн. 2. C. $472-531$.

87 Истрин В.М. Исследования в области древнерусской литературы. СПб.: Сенат. тип., 1906. 257 с.

88 Истрин В.М. Особый вид Еллинского летописца из собрания Тихонравова. СПб.: Тип. Имп. Акад. наук, 1912. С. 3-27.

89 Истрин В.М. Редакции Толковой Палеи. СПб.: Тип. Имп. Акад. наук, 1907. $188 \mathrm{c}$.

90 Истрин В.M. Редакции Толковой Палеи. Взаимоотношения полной и краткой Палей в пределах текста Палеи Коломенской // ИОРЯС. 1906. Т. ХІ. Кн. 1. C. 1-43.

91 Истрин B.M. Редакции Толковой Палеи. Описание полной и краткой Палей // ИОРЯС. 1905. Т. Х. Кн. 4. 135-203.

92 Истрин B.M. Толковая Палея и антиеврейская литература // Истрин B.M. Очерк истории древнерусской литературы домосковского периода (11-13 вв.). Пг.: Наука и школа, 1922. С. 213-224.

93 Истрин В.М. Толковая Палея и Хроника Георгия Амартола // ИОРЯС. Л., 1924. Т. ХХІХ. С. 369-379. 
94 Истрин В.М. Хроника Георгия Амартола в славяно-русском переводе и связанные с нею памятники // ЖМНП. 1917. Т. 59. Май. С. 1-35.

95 Истрин В.М. Хронографическая часть полной и краткой Палей и «Хронограф по великому изложению» // ИОРЯС. 1906. Т. ХІ. Кн. 2. С. 20-61.

96 Каган М.Д., Понырко Н.В., Рождественская М.В. Описание сборников XV в. книгописца Ефросина // ТОДРЛ. Л.: Наука, 1980. Т. 35. С. 3-300.

97 Каган-Тарковская М.Д. Легенда о дьяволе и Ноевом ковчеге по древнерусским рукописным сборникам // Исследования по древней и новой литературе / отв. ред. Л.А. Дмитриев. Л.: Наука, 1987. С. 108-110.

98 Камчатнов А.М. О семантическом словаре древнерусского языка // Древняя Русь. Вопросы медиевистики. 2000. № 1. С. 61-65.

99 Камчатнов А.М. Об издании «Палеи Толковой» в исторической ретроспективе и перспективе // «Палея Толковая» в контексте древнерусской культуры XI-XVII вв. Материалы Первой международной научной конференции / под ред. А.Н. Ужанкова. М.: Согласие, 2014. С. 231-237.

100 Камчатнов А.М. Орфография и текстология (заметки на полях Толковой Палеи) // Честному и грозному Ивану Васильевичу. К 70-летию Ивана Васильевича Левочкина. Сб. ст. / редкол.: И.Г. Добродомов и др. М.: РФК-Имидж Лаб, 2004. С. 23-24.

101 Карнеев А. К вопросу о взаимоотношениях Толковой Палеи и Златой Матицы // ЖМНП. 1900. Февраль. С. 335-366.

102 Козлова А.Ю. Вклад И.И. Срезневского в исследование Толковой Палеи // Двести лет со дня рождения академика Измаила Ивановича Срезневского: сб. докладов международной интернет-конференции (Ярославль, 1-31 марта 2012 г.) / под науч. ред., д-ра филол. наук О.В. Лукина. Ярославль: Изд-во ЯГПУ, 2012. С. 152-163.

103 Козлова А.Ю. Загадочные слова «клюще» и «ключь» Толковой Палеи // Русская речь. 1994. № 3. С. 75-80.

104 Козлова А.Ю. К вопросу о лингвистических особенностях старших списков «Толковой Палеи» // «Палея Толковая» в контексте древнерусской культуры XI-XVII вв. Материалы Первой международной научной конференции / под ред. А.Н. Ужанкова. М.: Согласие, 2014. С. 189-224.

105 Козлова А.Ю. К вопросу о лингвотекстологических особенностях старших списков Толковой Палеи (РНБ, СПбДА А. 1/119; РГАДА, Син. тип. № 53; РГБ. Тр.-Серг. № 38) // Международная филологическая конференция. Санкт-Петербургский университет. СПб., 2013. URL: http://www.conference-spbu.ru/ conference/13/ (дата обращения: 12.02.2019).

106 Козлова А.Ю. К вопросу о судьбе одного из сочинений Аристотеля в книжности Древней Руси // Язык и культура. Третья международная конференция. Тезисы докладов. Киев: Изд-во журнала «Collegium», 1994. С. 26-27.

107 Козлова А.Ю. Коломенский скрипторий XV в. (К вопросу о некоторых особенностях языка и орфографии Коломенского списка Толковой Палеи) // Материалы для энциклопедии «Коломенский край». Коломна: КПИ, 1997. Вып. 3-4. С. 13-19. 
108 Козлова А.Ю. Коломенский список Толковой Палеи как лексикографический источник // Словарное наследие В.П. Жукова и пути развития русской и общей лексикографии. Великий Новгород: НовГУ, 2004. С. 396-398.

109 Козлова А.Ю. Коломенский список Толковой Палеи 1406 г. как лингвистический источник: автореф. ... канд. филол. наук. Коломна, 2007. 25 с.

110 Козлова А.Ю. Лексические единицы, используемые для обозначения Высших сил, в коломенском списке Толковой Палеи 1406 года // Коломна и Коломенская земля: история и культура: сб. ст. / сост.: А.Г. Мельник, С.В. Сазонов. Коломна: Издат. дом «Лига», 2009. С. 105-117.

111 Козлова А.Ю. Лексический состав списка Коломенского списка Толковой Палеи 1406 г. // Владимир Даль и современная филология: Материалы международной научной конференции 22-23 ноября 2001 г. Нижний Новгород: НГЛУ им. Н.А. Добролюбова, 2001. С. 180-183.

112 Козлова А.Ю. Неславянская лексика в Коломенском списке Толковой Палеи 1406 г. // Язык и межкультурная коммуникация. Материалы Второй международной научно-практической конференции. Великий Новгород, 19-20 мая 2011 / отв. ред. О.А. Александрова, Е.Ф. Жукова. Великий Новгород: НовГУ, 2011. С. 77-85.

113 Козлова А.Ю. О некоторых особенностях передачи «Шестоднева» Иоанна экзарха Болгарского в разных списках Палеи Толковой редакции // Русское слово в историческом развитии (XIV-XIX века). Вып. 4: Материалы секции «Историческая лексикология и лексикография» XXXVII Международной филологической конференции. 11-15 марта 2008 г. / отв. ред. С.Св. Волков, О.С. Мжельская. СПб.: Нестор-История, 2009. С. 50-57.

114 Козлова А.Ю. О некоторых особенностях языковой личности редактора-составителя Толковой Палеи // Актуальные вопросы изучения духовной культуры. Материалы Международной научно-практической конференции «Славянская культура: истоки, традиции, взаимодействие. ХII Кирилло-Мефодиевские чтения» (17 мая 2011 г.). М.; Ярославль, 2011.

115 Козлова А.Ю. Особенности передачи трактата Аристотеля «Historia animalium» в древнейших списках Толковой Палеи // Международная коммуникация в современном мире. Материалы первой международной научной конференции. Тверь: [Б. и.], 2005. С. 225-230.

116 Козлова А.Ю. Отражение категории одушевленности в Коломенском списке Толковой Палеи 1406 г. // Грамматические категории и единицы: синтагматический аспект. Материалы шестой международной конференции. Владимир: ВГПУ, 2005. С. 83-86.

117 Козлова А.Ю. Палея Толковая начала XV века из Коломны // Вестник Коломенского государственного педагогического института. 2007. № 1 (12). С. 21-32.

118 Козлова А.Ю. Роль лингвистических данных в исследовании истории текста Толковой Палеи // Русский язык: исторические судьбы и современность. III Международный конгресс исследователей русского языка (Москва, МГУ им. М.В. Ломоносова, филологический факультет, 20-23 марта 2007 г: Труды и материалы. М.: МАКС Пресс, 2007. С. 64-65. 
119 Козлова А.Ю. Сведения о 12-летнем восточном календаре в «Толковой Палее» // Вспомогательные исторические дисциплины в современном научном знании. Материалы XXIX международной научной конференции. Москва, 13-15 апреля 2017 года. М.: ИВИ РАН, 2017. С. 183-185.

120 Козлова А.Ю. Толковая Палея как лексикологический и лексикографический источник // Актуальные проблемы функциональной лексикологии. Сб. статей, посвящ. 75-летию д. филол. наук, проф. В.В. Степановой. СПб.: Изд-во Санкт-Петербургского ун-та экономики и финансов, 1997. С. 53-56.

121 Козлова А.Ю. Толковая Палея - энциклопедия средневекового человека // Апостол. Церковно-культурный журнал. Коломна: Издание церкви апостола Иоанна Богослова, 2009. № 1. С. 14-15.

122 Козлова А.Ю. «Трудные» слова в текстах и словарях // ГДЛ. М.: Тип. «Нефтяник», 1994. С6. 6, ч. ІІ / отв. ред. В.М. Кириллин. С. 342-357.

123 Космологические произведения в книжности Древней Руси. Ч. II: Тексты плоскостно-комарной традиции / Изд. подгот. В.В. Мильков и С.М. Полянский. СПб.: Издат. дом «Миръ», 2009. 623 с.

124 Кузнецова В.С. Устное бытование библейской легенды об Иосифе Прекрасном: фольклоризация сюжета // Сибирский филологический журнал. 2010. № 4. С. $5-10$.

125 Кузьмин А.Г. Начальные этапы древнерусского летописания. М.: Наука, 1977. $394 \mathrm{c}$.

126 Кусков В.В. История древнерусской литературы. М.: Высшая школа, 1989. $800 \mathrm{c}$.

127 Леонид, архимандрит. Библиографические разыскания в области древнейшего периода славянской письменности IX-X вв. // ЧОИДР. 1890. Кн. 3. C. $1-28$.

128 Леонид, архимандрит. Четыре беседы Кесария, или вопросы святого Сильвестра и ответы преподобного Антония // ОЛДП. М., 1890. Т. XCV. 20 с.

129 Летописец Еллинский и Римский. Т. 2: Комментарии и исследования / Изд. подгот. О.В. Твороговым. СПб.: Дмитрий Буланин, 2001. 272 с.

130 Либан Н.И. Литература Древней Руси: Лекции-очерки. М.: Изд-во МГУ, 2000. $112 \mathrm{c}$.

131 Лихачев Д.С. Комментарии к «Повести временных лет» // Повесть Временных лет. М.; Л.: Изд-во АН СССР, 1950. Ч. II. 556 с.

132 Лихачев Д.С. Развитие русской литературы X-XVII веков. Эпохи и стили. Л.: Наука, 1973. 254 с.

133 Лончакова Г.А. О круге чтения новгородского писателя архиепископа Василия Калики (XIV в.) // Библиосфера. 2007. № 4. С. 60-70.

134 Лурье Я.С. Литературная и культурно-просветительская деятельность Ефросина в конце XV в. // ТОДРЛ. М.; Л.: Изд-во АН СССР, 1961. Т. 17. С. $130-168$.

135 Лурье Я.С. Переводная беллетристика XIV-XV вв. // Истоки русской беллетристики / отв. ред. Я.С. Лурье. Л.: Наука, 1970. С. 320-359. 
136 Львов А.С. Чешско-моравская лексика в памятниках древнерусской письменности // Славянское языкознание. VI Международной съезд славистов (Прага, август, 1968). М.: Наука, 1968. С. 316-338.

137 Максимович К.А. Птица Феникс в древнерусской литературе (к интерпретации образа) // ГДЛ. М.: ИРЛИ РАН, 1992. Сб. 5 / отв. ред. А.А. Косоруков. C. 316-334.

138 Матвеенко В.П., Щеголева Л.Н. Книги временные и образные Георгия Монаха. М.: Наука, 2006. Т. 1. Ч. 1. 554 с.

139 Месхина Ш.А., Цинцадзе Я.З. Из истории русско-грузинских взаимоотношений X-XVIII вв. Тбилиси: Заря Востока, 1958. С. 22-34.

140 Мещерский Н.А. Источники и состав древней славяно-русской переводной письменности IX-XV веков. Л.: Изд-во ЛГУ, 1978. 112 с.

141 Мещерский Н.А. К вопросу об изучении переводной письменности Киевского периода // Мещерский Н.А. Избранные статьи / отв. ред. и сост. Е.Н. Мещерская. СПб.: С.-Петербургский ун-т, 1995. С. 271-299.

142 Милтенов Я. Диалозите на Псевдо-Кесарий в славянската ръкописна традиция. София: Авалон, 2006. 600 с.

143 Милтенов Я. Ексцерпите от Диалозите на Псевдо-Кесарий в Тълковната Палея // Известия на Научен център «св. Дазий Доростолски». 2007. № 2. С. $183-196$.

144 Мильков В.В. Естественнонаучные сведения в «Толковой Палее» и их источники // Древняя Русь. Вопросы медиевистики. 2015. № 3 (61). С. 85-86.

145 Мильков В.В. Картина мира в Палее Толковой // Вестник славянских культур. 2016. № 3 (41). С. 7-23.

146 Мильков В.В. Космологические воззрения составителя «Палеи Толковой» // «Палея Толковая» в контексте древнерусской культуры XI-XVII вв. Материалы Первой международной научной конференции / под ред. А.Н. Ужанкова. М.: Согласие, 2014. С. 39-68.

147 Мильков В.В. Особенности трансляции естественнонаучных сведений античного происхождения в «Толковую Палею» // Вспомогательные исторические дисциплины в современном научном знании. Материалы XXIX международной научной конференции. Москва, 13-15 апреля 2017 года. М.: ИВИ PAH, 2017. С. 237-239.

148 Мильков В.В. Палейная антропология и ее источники // История философии. М.: ИФРАН, 2014. № 19. С. 21-36.

149 Мильков В.В. Палея Толковая // Русская философия. Энциклопедия / под общ. ред. М.А. Маслина. М.: Терра - Книжный клуб «Книговек», 2014. С. $457-459$.

150 Мильков В.В. Палея Толковая и ее религиозно-философские особенности (О расширении проблемного поля памятника в свете традиции его изучения) // Судьба России в современной историографии. Сб. научн. статей памяти д-ра ист. наук, проф. А.Г. Кузьмина / отв. ред. В.Л. Матросов. М.: «Прометей», МГПУ, 2006. С. 490-501. 
151 Мильков В.В. Религиозно-философское значение «Палеи Толковой» // Философские и богословские идеи в памятниках древнерусской мысли / отв. ред. М.Н. Громов и В.В. Мильков. М.: Наука, 2000. С. 108-113.

152 Милютенко Н.И. К вопросу о некоторых источниках Речи философа // ТОДРЛ. СПб.: Дмитрий Буланин, 2004. Т. 55. С. 9-17.

153 Михайлов А.В. К вопросу о происхождении и литературных источниках Толковой Палеи // ИОРЯС. 1928. Т. І. Кн. 1. С. 49-80.

154 Михайлов А.В. К вопросу о тексте книги Бытия и пророка Моисея в Толковой Палее // Варшавские университетские известия. 1895. № 9. С. 1-35.

155 Михайлов А.В. К вопросу о тексте книги Бытия и пророка Моисея в Толковой Палее // Варшавские университетские известия. 1896. № 1. С. 1-23.

156 Михайлов А.В. Общий обзор состава, редакций и литературных источников Толковой Палеи // Варшавские Университетские известия. 1895. № 7. 21 с.

157 Михайлов А.В. Опыт изучения текста книги Бытия пророка Моисея в древнеславянском переводе. Ч. I: Паримейный текст. Варшава: Тип. Варшавского учебн. окр., 1912. 824 с.

158 Мочульский В. Следы народной Библии в славянской и древнерусской письменности. Одесса, 1893. 285 с.

159 Назаревский О.А. К истории русско-украинских литературных связей // Вопросы русской литературы. Межведомственный республиканский научный сборник, изданный Черновицким государственным университетом. Львов: Изд. Львовского ун-та, 1967. Вып. 3 (6). С. 16-20.

160 Никольский Н. О литературных трудах митрополита Климента Смолятича, писателя XII века. СПб.: Тип. Имп. Акад. наук, 1892. 244 с.

161 Оболенский М.А. О греческом кодексе Георгия Амартола // ЧОИДР. 1846. № 4. Отд. IV. С. 73-102.

162 Орлов А.А. «Потаенные книги»: иудейская мистика в славянских апокрифах. М.; Иерусалим: Гершарим, 2011. 318 с.

163 Островский А. «Иосиф Прекрасный»: от сновидца к мученику // От Бытия к Исходу. Отражение библейских сюжетов в славянской и еврейской народной культуре. М.: ГЕОС, 1998. С. 181-192.

164 Палея Толковая по списку, сделанному в Коломне в 1406 г. / Труд учеников Н.С. Тихонравова. М.: Тип. и словолитня О. Гербска, 1892-1896. Вып. 1-2.

165 Памятники древнерусского канонического права. Часть I: Памятники XIXV вв. / Изд. подгот. А.С. Павловым // РИБ. СПб.: Печатня В.И. Головина, 1908. Т. 6. 1472 c.

166 Памятники старинной русской литературы, издаваемые графом Григорием Кушелевым-Безбородко. СПб.: Тип. Кулиша, 1862. Вып. 3: Ложные и отреченные книги русской старины, собранные А.Н. Пыпиным. 180 с.

167 Панайотов В.Б. Апокриф «Заветы двенадцати патриархов» в контексте Толковой Палеи: автореф. ... канд. филол. наук. М., 1986.

168 Панайотов В.Б. За редакциите на Тълковната палея // Епископ-Константинови четения. Шумен, 1996. Т. 2. С. 256-260. 
169 Панайотов В.Б. Проникване на старобългарски писмени паметници в Киевска Русия // Die Slawischen Sprachen. 1989. № 17. S. 75-83.

170 Перети B.Н. Исследования и материалы по истории старинной украинской литературы XVI-XVIII вв. Л.: Изд-во АН СССР, 1928. 255 с.

171 Пилявеи Л.Б. «Зерцало богословия» Кирилла Транквилиота-Ставровецкого и «Палея Толковая» // Отечественная общественная мысль эпохи Средневековья. Киев: Наукова думка, 1988. С. 245-250.

172 Пиотровская Е.К. Древнерусская версия «Христианской Топографии» Козьмы Индикоплова и «Толковая Палея» // ТОДРЛ. СПб.: Дмитрий Буланин, 1993. Т. 48. С. $138-142$.

173 Подскальски Г. Христианство и богословская литература Киевской Руси (988-1237 гг.) / пер. А.В. Назаренко. Серия: Subsidia Byzantinorossica. СПб.: Византинороссика, 1996. Т. 1.572 с.

174 Попов А.Н. Книга Бытия небеси и земли (Палея историческая). С приложением сокращенной палеи русской редакции. М.: Общество истории и древностей рос. при Моск. ун-те, 1881.320 с.

175 Попов Г.В. Миниатюры Псковской Палеи 1477 г. (о некоторых аспектах развития рукописной иллюстрации грозненского времени) // Древнерусское искусство: исследования и аттрибуция. СПб.: Дмитрий Буланин, 1997. С. 325-341.

176 Порфирьев И.Я. Апокрифические сказания о ветхозаветных лицах и событиях. Казань: Унив. тип., 1872. 309 с.

177 Порфирьев И.Я. Апокрифические сказания о ветхозаветных лицах и событиях по рукописям Соловецкой библиотеки // СОРЯС. СПб., 1877. T. XVII. № $1.276 \mathrm{c}$.

178 Протасьева Т.Н. Псковская Палея 1477 г. // Древнерусское искусство: Художественная культура Пскова / редкол.: В.Н. Лазарев, О.И. Подобедова, В.В. Косточкин. М.: Наука, 1968. С. 97-108.

179 Пурынычева Г.М. Сущность и истоки русской духовности (социально-философский анализ): автореф. ... д-ра филол. наук. М., 1999. 35 с.

180 Редин E. Толковая лицевая Палея XVI-го века собрания гр. А.С. Уварова // Памятники древней письменности и искусства. Отчеты о заседаниях Императорского общества любителей древней письменности в 1900-1901 году с приложениями. СПб.: Тип. И.Н. Скороходова, 1901. Т. CXLI. С. 1-9.

181 Робинсон А.Н. Литература Древней Руси в литературном процессе Средневековья XI-XVIII вв. М.: Наука, 1980. 336 с.

182 Рождественская М.В. Библейские апокрифы в литературе и книжности Древней Руси: историко-литературное исследование: авторефю дис. ... д-ра филол. наук. СПб., 2004. 79 с.

183 Русский вестник. 1892. № 1.432 с.

184 Рыстенко А.В. Материалы для литературной истории Толковой Палеи // ИОРЯС. 1908. Т. ХІІІ. Ч. 2. С. 324-334.

185 Сводный каталог славяно-русских рукописных книг, хранящихся в СССР. XI-XIII в. / отв. ред. Л.П. Жуковская. М.: Наука, 1984. 405 с. 
186 Сергеев В.Н. Об одной особенности в иконографии ветхозаветной «Троицы» // Древнерусское искусство XV-XVII веков / отв. ред. В.Н. Сергеев. М.: Искусство, 1981. С. 26-31.

187 Славова Т. Някои средновековыи представи за човешката физиология и ембриология // Eslovistica Computense. 2002. № 2. С. 243-251.

188 Славова Т. Тълковната палея в контекста на старобългарската книжнина. София: Университетско Изд-во «Св. Климент Охридски», 2002. 577 с.

189 Словарь книжников и книжности Древней Руси. СПб.: Наука, 1989. Вып. 2: Вторая половина XIV-XVI в. Ч. 2. 528 с.

190 Смирнов А.А. Заветы двенадцати патриархов, сыновей Иакова. Казань: Типолитогр. Имп. ун-та, 1911. 301 с.

191 Смирнов И. Описание рукописных сборников Новгородской Софийской библиотеки // ЛЗАК. СПб., 1864. Вып. III. Отд. 3. 106 с.

192 Соболевский А.И. Несколько слов о лицевых рукописях // ИОРЯС. СПб., 1908. Т. ХІІІ. Кн. 1. С. 95-96.

193 Срезневский И.И. Сказание о святых Борисе и Глебе: Сильвесторовский список XIV в. СПб.: Тип. Имп. Акад. наук, 1860. 147 с.

194 Срезневский И.И. Словарь древнерусского языка. М.: Книга, 1989. Т. ІІ. Ч. 2. 854-1802 стб.

195 Станков Р.А. Древнерусская книжная и народная лексика в языке Исторической Палеи: автореф. ... канд. филол. наук. М., 1985. 25 с.

196 Станков Р.А. Историческая Палея - памятник болгарской культуры // Palaeobulgarica - Старобългаристика. 1986. № 4. С. 55-63.

197 Строев П. Хронологическое указание материалов отечественной истории, литературы, правоведения до начала XVIII столетия // ЖМНП. 1834. Ч. 2. 37 с.

198 Сухомлинов М.И. О древней русской летописи, как памятнике литературном. СПб.: В тип. Имп. Акад. наук, 1856. 269 с.

199 Творогов О.В. Древнерусские хронографы / отв. ред. Я.С. Лурье. Л.: Наука, $1975.320 \mathrm{c}$.

200 Творогов О.В. К ранним русско-еврейским литературно-текстовым связям (XI-XVI вв.) // Славяне и их соседи. М.: Наука, 1993. С. 46-54.

201 Творогов О.В. Летопись - Хроника - Палея (взаимоотношение памятников и методика их исследования) // Армянская и русская средневековая литературы / сост. К.В. Айвазян; отв. ред. Д.С. Лихачев. Ереван: Изд-во АН АрмССР, 1986. С. 19-30.

202 Тихонравов Н.С. История российской словесности древней и новой. Сочинение А. Галахова (рец.) // Отчет о девятнадцатом присуждении наград гр. Уварова. 25 сентября 1876 г. СПб.: В тип. Имп. Акад. наук, 1878. 124 с.

203 Тихонравов Н. С. Памятники отреченной литературы. М.: В тип. тов-ва «Общественная польза», 1863. Т. І. 313 с.

204 Тихонравов Н.С. Сочинения: в 3 т. СПб.: Изд-е М. и С. Сабашниковых, 1898. T. $1.583 \mathrm{c}$.

205 Толковая палея 1477 г. Воспроизведение Синодальной рукописи № 210 // ОЛДП. СПб., 1892. Т. ХCIII. Вып. І. 302 с. 
206 Топоров В.Н. Святость и святые в русской духовной культуре. М.: Языки русской культуры, 1995. Т. 1: Первый век христианства на Руси. 873 с.

207 Ужанков А.Н. Книга неба и земли // «Палея Толковая» в контексте древнерусской культуры XI-XVII вв. М.: Согласие, 2014. С. 7-8.

208 Успенский Б.А. Филологические наблюдения над текстом «Откровения Авраама» // Вопросы языкознания. 2015. № 5. С. 49-86.

209 Успенский В. Толковая Палея. Казань: Тип. Имп. ун-та, 1876. 134 с.

210 Хазанова С.И. Апокрифы о Моисее в древнерусской письменности // Русь, Россия. Средневековье и Новое время. 2013. № 3. С. 128-136.

211 Хазанова С.И. Отрывок из «Откровения Авраама» в Палее Толковой с отдельными вставками, встречающимися в Хронографической Палее собрания Ундольского // Вспомогательные исторические дисциплины в современном научном знании. Материалы XXIX международной научной конференции. Москва, 13-15 апреля 2017 года. М.: ИВИ РАН, 2017. C. $320-322$.

212 Черная Л.А. Взгляд на человеческую природу в древнерусской литературе // Древнерусская литература: Изображение природы и человека / отв. ред. А.С. Демин. М.: Специализир. изд.-торговое предприятие «Наследие», 1995. C. 127-157.

213 Чолова Ц. Естествено-научните знания в средновековна България. София: Изд-во на Бълг. акад. науките, 1988. 401 с.

214 Шахматов А.А. Повесть временных лет и ее источники // ТОДРЛ. М.; Л.: Изд-во АН СССР, 1940. Т. 4. С. 9-150.

215 Шахматов А.А. Толковая Палея и русская летопись // Шахматов А.А. Статьи по славяноведению. СПб., 1904. Вып. 1. С. 199-272.

216 Щеглов А.П. Древнерусская ноуменальная натурфилософия. М.; Иерусалим: [Б.и.], 1999. 200 с.

217 Щеглов А.П. Религиозно-философское содержание Толковой Палеи // Журнал Историко-богословского общества. М., 1991. Вып. 2. С. 7.

218 Щеглов А.П. Философское содержание «Толковой Палеи» по материалам русских рукописей: автореф. ... канд. филол. наук. М., 1994. 18 с.

219 Ярошенко-Титова Л.В. «Повесть об увозе Соломоновой жены» в русской летописной традиции XVII-XVIII вв. // ТОДРЛ. Л.: Наука, 1974. Т. 29. С. 257-273.

220 Louria J. Une legende inconnue de Solomon et Kitovras dans un manuscrit du XV siecle // Revue des Etudes Slaves. 1964. T. 43. P. 7-11.

221 Michajlov A. Zur Entstehungsgeschichte der «Tolkovaja Paleja» // Zeitschrift fur Slavische Philologie. 1927. Bd. 4. S. 115-131.

222 Philonenko-Sayar B, Philonenko M. L'Apocalypse d'Abraham. Introduction, texte slave, traduction et notes // Semitica. № 341. Paris, 1981. P. 37-105.

223 Rubinkiewicz R. L'Apocalypse d'Abraham. Introduction, texte critique, traduction et commentaire. Lublin: Towarzystwo Naukowe Katolickiego Uniwersytetu Lubelskiego, 1987.

224 Taube M. The Slavic Life of Moses and Hebrew Sources // Jews and Slavs. St. Petersburg; Jerusalem, 1993. Vol. 1. P. 93-114. 
225 Thomson FJ. The Slavonic Translation of the Old Testament // Interpretation of the Bible. Ljubljana; Sheffield, 1998.

226 Trunte N. Paleja Tolkovaja (рец.) // Zeitschrift fur Slavische Philologie. Bd. 62. 2003. S. 440-445.

227 Turdeanu E. La Chronique de Moïse en russe // Revue des Etudes Slaves. 1967. Vol. 46. P. 35-64.

228 URL: http://www.mamif.org.paleja.htm (дата обращения: 12.02.2019).

\section{REFERENCES}

1 Adrianova V.P. K literaturnoi istorii Tolkovoi Palei [To the literary history of the Explanatory Paleia]. Kiev, Tip. Akts. O-va "Petr Barskii v Kieve" Publ., 1910. 77 p. (In Russian)

2 Alekseev A.A. Apokrify Tolkovoi Palei, perevedennye s evreiskikh originalov [The Explanatory Paleia's apocrypha, translated from Hebrew]. Trudu Otdela drevnerusskoi literatuty [Researchers of the Department of Old Russian literature]. St. Petersburg, Dmitrii Bulanin Publ, 2007, vol. 58, pp. 41-57. (In Russian)

3 Alekseev A.A. Paleia v sisteme khronograficheskogo zhanra [Paleia in the system of chronographic genre]. Trudu Otdela drevnerusskoi literatury. [Researchers of the Department of Old Russian literature]. St. Petersburg, Dmitrii Bulanin Publ., 2006, vol. 57, pp. 25-32. (In Russian)

4 Alekseev A.A. Perevody Biblii [Bible translations]. Istoriia evreiskogo naroda $v$ Rossii. Ot drevnosti do rannego Novogo vremeni [The history of the Jewish people in Russia. From antiquity to early modern times], ed. by A. Kulik. Moscow, Ierusalim, Mosty kul'tury, Gesharim Publ., 2010, vol. 1, pp. 345-355. (In Russian)

5 Alekseev A.A. Perevody s drevneevreiskikh originalov v Drevnei Rusi [Translations from Hebrew originals in Old Russia]. Russian Linguistics, 1987, vol. XI, no 1, pp. 1-20. (In Russian)

6 Alekseev A.A. Russko-evreiskie literaturnye sviazi do XV v. [Russian-Jewish literary relations up to the $15^{\text {th }}$ century]. Jews and Slavs, eds. by W. Moskovich, S. Shvarzband, A. Alekseev. Ierusalem, St. Petersburg, Nauka Publ., 1993, vol. 1, pp. 44-75. (In Russian)

7 Alekseev A.A. Tekstologiia slavianskoi Biblii [Textology of the Slavonic Bible]. St. Petersburg, Dmitrii Bulanin Publ., 1999. 256 p. (In Russian)

8 Apokrifi i legendi $z$ ukrä̈n'kikh" rukopisiv, zibirav, uporiadkuvav $i$ poiasniv Iv. Franko [Apocrypha and legends from Ukrainian manuscripts, collected, ordered and explained by I. Franco]. L'viv, Nakladom nauk. t-va im. Shevchenka Publ., 1896. Vol. I (Apokrifi starozavitni). 512 p.

9 Apokrify Drevnei Rusi [the Apocrypha of Old Russia], comp. by M.V. Rozhdestvenskaya. St. Petersburg, Amfora Publ., 2002. 238 p. (In Russian)

10 Arkhangel'skii A.S. Tvoreniia ottsov tserkvi v drevnerusskoi pis'mennosti [Creations of the Fathers of the Church and Old Russian writing]. Kazan', Tip. Imp. un-ta Publ., 1889. Vol. I-II. 203 p. (In Russian)

11 Barankova G.S. O vzaimootnosheniiakh "Shestodneva" Ioanna ekzarkha 
Bolgarskogo i "Tolkovoi Palei" (tekstologo-lingvisticheskii aspekt) [About the relationship of the "Hexaemeron" of St. John the Exarch of the Bulgarian and the Explanatory Paleia (textlogo-linguistic aspect)]. Istoriia russkogo iazyka. Issledovaniia $i$ teksty [History of Russian language. Studies and texts], eds. by V.G. Dem'ianov, V.F. Dubrovina. Moscow, Nauka Publ., 1982, pp. 262-277. (In Russian)

12 Barankova G.S., Mil'kov V.V. Shestodnev Ioanna ekzarkha Bolgarskogo [The Hexaemeron of John the Exarch of the Bulgarian]. Seriia: Pamiatniki drevnerusskoi mysli: issledovaniia i teksty [Series: Monuments of Old Russian thought: research and texts.]. St. Petersburg, Aleteiia Publ., 2001. Issue II. 972 p. (In Russian)

13 Belobrova O.A. Etiketnyi motiv v drevnerusskoi miniatiure XV v. [Etiquette motif in old Russian miniature of the $15^{\text {th }}$ century]. Issledovaniia po drevnei $i$ novoi literature [Researches on Old and new literature], ed. by Iu.K. Gerasimov. Leningrad, Nauka Publ., 1987, pp. 25-31. (In Russian)

14 Belova O.V. "Bystroskochi vaser" nabor" zazhei rys'..” (o "govoriashchikh" oshibkakh v drevnerusskikh skazaniiakh o zhivotnykh) ["Bystroskochi vaser" nabor" zazhei rys'.." (about "speaking" errors in the old legend of the animals)]. Slavianskie etiudy. Sb. $k$ iubileiu S.M. Tolstoi [Slavic studies. Collection for the anniversary of S.M. Tolstaia], ed. by E.E. Levkievskaia. Moscow, Indrik Publ., 1999, pp. 70-85. (In Russian)

15 Belova O.V. Obobshchaiushchie nazvaniia zhivotnykh v slavianskom "Fiziologe" [Generalizing names of animals in Slavic "Physiologist"]. Rol' bibleiskikh perevodov $v$ razvitii literaturnykh iazykov $i$ kul'tury slavian. Tezisy dokladov mezhdunarodnoi nauchnoi konferentsii (Moskva, 23-24 noiabria 1999 g.) [The Role of biblical translations in the development of literary languages and culture of the Slavs. Theses of reports of the international scientific conference (Moscow, November 23-24, 1999)], ed. by L.N. Smirnov. Moscow, In-t slavianovedeniia Publ., 1999, pp. 3-6. (In Russian)

16 Bersenev P.V. O chem molchit Bibliia [About what the Bible is silent]. Vetkhozavetnye apokrify: Kniga Iubileev; Zavety dvenadtsati patriarkhov [The old Testament Apocrypha: Book of Anniversaries; Covenants of the twelve patriarchs], transl. by A.V. Smirnov; comp. and comment. by P.V. Bersenev. St. Petersbyrg, Amfora Publ., 2000, pp. 5-12. (In Russian)

17 Biblioteka literatury Drevnei Rusi. [Library of Old Russian literature]. St. Petersburg, Nauka Publ., 1999. Vol. 3. 544 p. (In Russian)

18 Bondar' K.V. Davnorus'ki povisti Solomonovogo tsiklu: dzherela, tekstologiia, problematika, poetika [The ancient stories of Solomon's cycle: sources, textual criticism, issues, poetics: PhD thesis, summary]. Kharkiv, 2007. 19 p. (In Russian)

19 Bondar' K.V. K voprosu o evreiskikh istochnikakh paleinoi "Povesti o Kitovrase" [To the question of Jewish sources of "the Story about Kitovras" in Paleja]. Materialy Vos'moi ezhegodnoi mezhdunarodnoi mezhdistsiplinarnoi konferentsii po iudaike [Proceedings of the eighth annual international conference on Judaism]. Moscow, 2001, part 2, pp. 136-144. (In Russian) 
20 Bondar' K.V. K istorii teksta povestei o Solomone v Palee [To the history of the text of the story of Solomon in Paleja]. Naukovi zapiski Kharkivs'kogo natsional'nogo pedagogichnogo uniiversitetu im. G.S. Skovorodi. Seriia: Literaturoznavstvo. [Scientific notes of Kharkiv national pedagogical University. G.S. Skovoroda. Series: Literaturoznavstvo]. Kharkiv, 2010, no 4 (64). Available at: http://nbuv.gov. ua/UJRN/Nzl_2010_4.1_3. (Accessed 12 February 2019). (In Russian)

21 Bondar' K.V. Nabliudeniia nad rukopisnym konvoem povestei o Solomone [Observation on the handwritten escort stories about Solomon]. Naukovi zapiski Kharkivs'kogo natsional'nogo pedagogichnogo uniiversitetu im. G.S. Skovorodi. Seriia: Literaturoznavstvo [Scientific notes of Kharkiv national pedagogical University. G.S. Skovoroda. Series: Literaturoznavstvo]. Kharkiv, 2006, issue 4 (48), part 2, pp. 164-168. (In Russian)

22 Bondar' K.V. "O Kitovrase ot Palei” i drugie siuzhety knigopistsa Efrosina ["On Kitovras from Paleja" and other stories of the scribe Euphrosynus]. Materialy Sed'moi ezhegodnoi mezhdunarodnoi mezhdistsiplinarnoi konferentsii po iudaike [Proceedings of the seventh annual international conference on Judaism]. Moscow, 2000, part 2, pp. 123-129. (In Russian)

23 Bondar' K.V. Povesti o Solomone v nauke o literature [Stories about Solomon in the science of literature]. Dvenadtsatye mezhdunarodnye chteniia molodykh uchenykh pamiati L.Ia. Livshitsa [Twelfth international readings of young scientists in memory of L.Y. Livshits]. Khar'kov, 2007, pp. 14-15. (In Russian)

24 Bondar' K.V. Povesti Solomonova tsikla: iz slaviano-evreiskogo dialoga kul'tur [Stories of the Solomon cycle: from the Slavonic-Jewish dialogue of cultures]. Khar'kov, Novoe slovo Publ., 2011. 156 p. (In Russian)

25 Bondar' K.V. Rukopisnye dannye po probleme Solomonovykh skazanii [Handwritten information on the issue of the Solomon legends]. Tirosh: Trudy po iudaike [Tires: Writings on Judaism]. Moscow, 2005, issue 7, pp. 88-93. (In Russian)

26 Bondar' K.V. Slavianskie Sudy Solomona: istochniki, sostav, tekstologiia [Slavic Courts of Solomon: sources, composition, textual criticism]. Materialy Dvenadtsatoi ezhegodnoi mezhdunarodnoi mezhdistsiplinarnoi konferentsii po iudaike [Proceedings of the twelfth annual international interdisciplinary conference on Judaism]. Moscow, In-t slavianovedeniia Publ., 2005, part 1, pp. 352-356. (In Russian)

27 Bondar' K.V. Solomonov tsikl po rannim spiskam [Solomon cycle on early lists]. IX konferentsiia molodykh uchenykh «Voprosy slaviano-russkogo rukopisnogo naslediia» ( $k$ 75-letiiu Otdela drevnerusskoi literatury IRLI RAN). 29 sentiabria 2 oktiabria 2008. [ $9^{\text {th }}$ conference of young scientists "Questions of Slavonic-Russian manuscript heritage" (to the 75th anniversary of the Department of Old Russian literature IRLI RAS). September 29 - October 2, 2008]. St. Petersburg, 2008. Available at: http://odrl.pushkinskijdom.ru/Default.aspx?tabid=7822 (Accessed 12 February 2019). (In Russian)

28 Bondar' K.V. Tsar' Solomon v russkikh rukopisnykh sbornikakh [King Solomon 
in the Russian manuscript collections]. 2000 let khristianstva. Problemy istorii $i$ kul'tury: Materialy nauchn. konf. [2000 years of Christianity. Problems of history and culture: Proceedings of the scientific conference]. Kolomna, Kolom. gos. ped. in-t Publ., 2000, pp. 45-46. (In Russian)

29 Bondar' K.V. Etiud ob Asmodee i Kitovrase [Study about Asmodee and Kitovras]. Tirosh: Trudy po iudaike [Tires: Writings on Judaism], ed. by M. Chlenov. Moscow, Judaica Rossica Publ., issue 8, pp. 111-114. (In Russian)

30 Bortsova I.V. Legendarnye ekskursy o razdelenii zemli v drevnerusskoi literature [Legendary narratives about the division of land in Old Russian literature]. Drevneishie gosudarstva na territorii SSSR. $1987 \mathrm{~g}$. [The Earliest States on the territory of the USSR. 1987], ed. by A.P. Novosel'tsev. Moscow, Nauka Publ., 1989, pp. 178-184. (In Russian)

31 Boriushkina E.N. "Grekh" i "bezakonie" v Tolkovoi Palee ["Sin" and "bethanie" in Explanatory Paleia]. Drevniaia Rus'. Voprosy medievistiki [Old Russia. The questions of middle ages]. 2013, no 4 (54), pp. 49-54. (In Russian)

32 Boriushkina E.N. Osobennosti upotrebleniia slov gordost' i gordynia v "Tolkovoi Palee" [Features of the use of the words pride and arrogance in Explanatory Paleia]. "Paleia Tolkovaia" v kontekste drevnerusskoi kul'tury XI-XVII vv. Materialy Pervoi mezhdunarodnoi nauchnoi konferentsii [Explanatory Paleia in the context of old culture of $11^{\text {th }}-17^{\text {th }}$ centuries. Materials of the First international scientific conference], ed. by A.N. Uzhankov. Moscow, Soglasie Publ., 2014, pp. 225-230. (In Russian)

33 Boriushkina E.N. Otvlechennaia leksika v Tolkovoi Palee [An abstract vocabulary in Explanatory Paleia: PhD thesis, summary]. Moscow, 2013. 24 p. (In Russian)

34 Boriushkina E.N. Problemy perevoda slova zhivot, zhitie, zhizn' v Tolkovoi Palee [The problem of the translation of the word belly, life, intelligent life in Explanatory Palee]. Nauchno-tekhnicheskaia informatsiia. Ser. 2: Informatsionnye protsessy $i$ sistemy [Scientific and technical information. Series 2: Information processes and systems]. Moscow, VINITI Publ., 2012, no 8, pp. 25-28. (In Russian)

35 Boriushkina E.N. Spetsifika poniatiia "otvlechennaia leksika" v drevnerusskom iazyke [The specificity of the concept of "abstract language" in the Old Russian language]. Vestnik Nizhegorodskogo universiteta im. N.I. Lobachevskogo, 2010, no 4 (2), pp. 448-450. (In Russian)

36 Boriushkina E.N. Chlenenie semanticheskogo ob"ema mnogoznachnogo slova $\mathrm{v}$ drevnerusskom iazyke kak problema istoricheskoi leksikografii (na primere analiza slova "svet" v Palee Tolkovoi) [The articulation of the semantic volume of polysemous words in the Old Russian language as a problem of historical lexicography (on the example of analysis of the word "light" in Explanatory Paleia)]. Institut XXI vek: podgotovka pedagogicheskikh kadrov (aktual'nost', problemy, perspektivy). Materialy nauchno-prakticheskoi konferentsii [Institute of the $21^{\text {st }}$ century: teacher training (relevance, problems, prospects). Materials of scientific and practical conference], eds. by E.G. Chernysheva, O.V. Senenko, O.N. Shumkina. Moscow, MGPI Publ., 2009, vol. 1, issue 4, pp. 95-97. (In Russian) 
37 Bylinin V.K. "Khudozhestvo": izobrazhenie zodchego v drevnerusskoi literature ["Art": the image of the architect in the Old Russian literature]. Drevnerusskaia literatura: Izobrazhenie obshchestva [Old Russian literature: the Image of society]. Moscow, Nauka Publ., 1991, pp. 118-154. (In Russian)

38 Verevskii F. Russkaia istoricheskaia Paleia [Russian historical Paleia]. Filologicheskie zapiski [Philological notes]. Voronezh, 1888, vol. 2, pp. 1-18. (In Russian)

39 Veselovskii A.N. Zametki po literature i narodnoi slovesnosti: 1. Epizod o iuzhnoi tsaritse v Palee [Notes on literature and folk literature: 1. The episode of South Queen in Paleja]. Sbornik otdeleniia russkogo iazyka i slovesnosti [Collection of the Department of Russian language and literature]. 1883, vol. 32, no 7, pp. 1-8. (In Russian)

40 Veselovskii A.N. Talmudicheskii istochnik odnoi Solomonovoi legendy v russkoi Palee [Talmudic source of one Solomon's legend in the Russian Paleja]. Zhurnal ministerstva narodnogo prosveshcheniia? 1880, Aprel', pp. 298-300. (In Russian)

41 Vikul T. Tolkovaia Paleia i Povest' vremennykh let. Siuzhet o "razdelenii iazyk" [Explanatory Paleia and the Tale of bygone years. The plot of the "separation of languages"]. Ruthenica? 2007, no 6, pp. 37-85. (In Russian)

42 Vodolazkin E.G. Vsemirnaia istoriia $v$ literature Drevnei Rusi (na materiale khronograficheskogo i paleinogo povestvovaniia) [The world history in the literature of Old Russia (on the material of chronological and paleja 's narrative)]. Miunkhen, Sagner Publ., 2000. 408 p. (In Russian)

43 Vodolazkin E.G. Efrosinovskaia Paleia: do i posle [Paley's Efrosinovska: before and after]. Russica romana, 2007, vol. 14, pp. 9-22. (In Russian)

44 Vodolazkin E.G. Iz istorii drevnerusskogo istoricheskogo povestvovaniia. Kratkaia Khronograficheskaia Paleia [From the history of the Old Russian historical narrative. A brief Chronological Paley]. Vspomogatel'nye istoricheskie distsipliny [Auxiliary historical disciplines], ed. by V.N. Pleshkov. St. Petersburg, Dmitrii Bulanin Publ., 2007, vol. 30, pp. 341-349. (In Russian)

45 Vodolazkin E.G. K voprosu ob arabskikh naimenovaniiakh planet v drevnerusskoi knizhnosti [To the question about the Arabic names of the planets in Old Russian literature]. Trudu Otdela drevnerusskoi literatury [Researches of the Department of Old Russian literature]. St. Petersburg, Dmitrii Bulanin Publ., 1996, vol. 49, pp. 677-683. (In Russian)

46 Vodolazkin E.G. Kak sozdavalas' Polnaia Khronograficheskaia Paleia. Chast' 1 [How to create a Full Chronological Paley. Part 1]. Trudu Otdela drevnerusskoi literatury [Researches of the Department of Old Russian literature]. St. Petersburg, Dmitrii Bulanin Publ., 2009, vol. 60, pp. 327-353. (In Russian)

47 Vodolazkin E.G. Kak sozdavalas' Polnaia Khronograficheskaia Paleia. Chast' 2 [How to create a Full Chronological Paley. Part 2]. Trudu Otdela drevnerusskoi literatury [Researches of the Department of Old Russian literature]. St. Petersburg, Dmitrii Bulanin Publ., 2014, vol. 62, pp. 175-198. (In Russian)

48 Vodolazkin E.G. Kratkaia Khronograficheskaia Paleia: mezhdu istoriografiei i bogosloviem [A brief Chronological Paley: between historiography and theology]. Vestnik istorii, literatury, iskusstva. [Bulletin of history, literature, art]. Moscow, 
Nauka Publ., 2006, vol. 2, pp. 233-244. (In Russian)

49 Vodolazkin E.G. Kratkaia Khronograficheskaia Paleia (tekst). Vyp. 2 [A brief Chronological Paley (text). Issue 2]. Trudu Otdela drevnerusskoi literatury [Researches of the Department of Old Russian literature]. St. Petersburg, Dmitrii Bulanin Publ., 2007, vol. 58, pp. 341-349. (In Russian)

50 Vodolazkin E.G. Novoe o paleiakh (nekotorye itogi i perspektivy izucheniia paleinykh tekstov) [New about Paley (some results and prospects of studying Paley texts)]. Russkaia literature, 2007, no 1, pp. 3-23. (In Russian)

51 Vodolazkin E.G. O Tolkovoi Palee, Zlatoi Matitse i "estestvennonauchnykh" kompiliatsiiakh [About Explanatory Paleia, Golden Matica and "science" compilations]. Trudu Otdela drevnerusskoi literatury [Researches of the Department of Old Russian literature]. St. Petersburg, Dmitrii Bulanin Publ., 1999, vol. 51, pp. 80-90. (In Russian)

52 Vodolazkin E.G. Redaktsii Kratkoi Khronograficheskoi Palei [Editions of the Brief Chronological Paley]. Trudu Otdela drevnerusskoi literatury [Researches of the Department of Old Russian literature]. St. Petersburg, Dmitrii Bulanin Publ., 2004, vol. 56, pp. 164-180. (In Russian)

53 Vologina E.Z. Eshche raz o tekstologii “Zavetov 12 patriarkhov" v drevnerusskoi knizhnosti [Once again about the textual criticism of "Testaments of the 12 patriarchs" in Old Russian literature]. XLIII Mezhdunarodnaia filologicheskaia nauchnaia konferentsiia. 11-16 marta 2014 g. Tezisy [Philology, XLIII international scientific conference. 11-16 March 2014 Abstracts]. St. Petersburg, SPbGU Publ., 2014, p. 174. (In Russian)

54 Vostokov A.Kh. Opisanie russkikh $i$ slavianskikh rukopisei Rumiantsevskogo Muzeuma [Description of Russian and Slavonic manuscripts of the Rumyantsev Museum]. St. Petersburg, V tip. Imp. AN Publ., 1842. 902 p. (In Russian)

55 Gavriushin N.K. Kosmologicheskii traktat XV veka kak pamiatnik drevnerusskogo estestvoznaniia [Cosmological treatise of $15^{\text {th }}$ century as a monument of Old Russian natural history]. Pamiatniki nauki i tekhniki [Monuments of science and technology], ed. by L. Maistrov. Moscow, Nauka Publ., 1981, pp. 183-197. (In Russian)

56 Gadalova G.S. K voprosu o redaktsiiakh i literaturnykh istochnikakh azbuchnykh stikhov ob Adame [To the question of editions and literary sources of elementary poems about Adam]. Drevniaia Rus'. Voprosy medievistiki, 2008, no 4, pp. 58-77. (In Russian)

57 Garicheva E.A. Zoomorfnaia i rastitel'naia simvolika v "Tolkovoi Palee" [Zoomorphic and vegetal symbolism in Explanatory Paleia]. "Paleia Tolkovaia" $v$ kontekste drevnerusskoi kul'tury. Materialy Pervoi mezhdunarodnoi nauchnoi konferentsii ["Paley Explanatory" in the context of old culture. Proceedings of the First international scientific conference], ed. by A.N. Uzhankov. Moscow, Soglasie Publ., 2014, pp. 135-153. (In Russian)

58 Gerasimova I.A. Drevnerusskaia "Paleia": tolkovanie trudnykh voprosov mirozdaniia [The Old Russian Paleia: the interpretation of difficult questions of the universe]. Del'fis [Delfis], 2013, no 2, pp. 64-71. (In Russian) 
59 Gerasimova I.A. “Tolkovaia Paleia”, antichnaia nauka i zhiteiskii opyt [Explanatory Paleia, ancient science and everyday experience]. «Paleia Tolkovaia» v kontekste drevnerusskoi kul'tury XI-XVII vv. Materialy Pervoi mezhdunarodnoi nauchnoi konferentsii [Explanatory Paleia in the context of Old Russian culture of the $11^{\text {th }}$ $17^{\text {th }}$ centuries. Materials of the First international scientific conference], ed. by A.N. Uzhankov. Moscow, Soglasie Publ., 2014, pp. 15-38. (In Russian)

60 Gerasimova I.A., Mil'kov V.V. Tolkovaia Paleia o mirozdanii i poznanii [Explanatory Paleia about the universe and knowledge]. Epistemologiia $i$ filosofiia nauki, 2013, no 2 (36), pp. 178-194. (In Russian)

61 Gorina L.V. Vizantiiskaia i slavianskaia khronografiia (sushchestvoval li bolgarskii khronograf) [The Byzantine and Slavic chronographia (was there a Bulgarian chronograph)] Vizantiia. Sredizemnomor'e. Slavianskii mir: Sbornik $k$ XVIII Mezhdunarodnomu kongressu vizantinistov [Byzantium. Mediterranean. Slavic world: Collection to the $18^{\text {th }}$ international Congress of Byzantines], eds. by G.G. Litavrin etc. Moscow, Izd-vo MGU Publ., 1991, pp. 121-129. (In Russian)

62 Gorskii A.V., Nevostruev K.I. Opisanie slavianskikh rukopisei Moskovskoi sinodal'noi biblioteki. Otd. II: Pisaniia sviatykh ottsov. Ch. 1: Tolkovanie Sviashchennogo Pisaniia. [Description of Slavic manuscripts of the Moscow Synodal library. Chapter II: The writings of the Holy fathers. Part 1: Interpretation of Scripture]. Moscow, Sinod. tip. Publ., 1857. 209 p. (In Russian)

63 Gorskii A.V., Nevostruev K.I. Opisanie slavianskikh rukopisei Moskovskoi Sinodal'noi biblioteki. Otd. II: Pisaniia sviatykh ottsov. Ch. 2: Pisaniia dogmaticheskie $i$ dukhovno-nravstvennye [Description of Slavic manuscripts of the Moscow Synodal library. Chapter II: The writings of the Holy fathers. Part 2: dogmatic and spiritual-moral writings]. Moscow, Sinod. tip. Publ., 1859. 705 p. (In Russian)

64 Gribov Iu.A. Znachenie paleograficheskikh osobennostei dlia opredeleniia sostava i genealogii chet'ikh sbornikov [The Value of the paleographic features to determine the composition and genealogy collection of readings written]. Istoriia i paleografiia [History and paleography], ed. by V.I. Buganov. Moscow, IRI RAN Publ., 1993, vol. 1, pp. 34-49. (In Russian)

65 Gribov Iu.A. O rekonstruktsii novgorodskogo illiustrirovannogo sbornika XIV v. [About the reconstruction of the Novgorod illustrated collection of the $14^{\text {th }}$ century]. Khrizograf. Vyp. 3: Srednevekovye knizhnye tsentry: mestnye traditsii $i$ mezhregional'nye sviazi [Risograph. Issue 3: Mediaeval book centres: local traditions and inter-regional ties], comp. by E.N. Dobrynina. Moscow, Skanrus Publ., 2009, pp. 253-267. (In Russian)

66 Grishchenko A.I. Naimenovanie evreev v drevnerusskikh antiiudeiskikh sochineniiakh: $\mathrm{k}$ istorii ekspressivnosti etnonima zhidove [The name of the Jews in the ancient anti-Judaic writings: the history of the expressiveness of the ethnonym zhidove]. Nauchnye trudy po iudaike. Materialy XVIII Mezhdunarodnoi ezhegodnoi konferentsii po iudaike [Scientific works on Judaism. Proceedings of the $18^{\text {th }}$ international annual conference on Judaism], ed. by V.V. Mochalova. Moscow, Sefer Publ., 2011, vol. 1, pp. 189-204. (In Russian)

67 Grishchenko A.I. O gebraizme mashliakh" "Messias" v Palee Tolkovoi [About 
hebraism maslany "Messias" in Explanatory Paleia]. Vestnik Literaturnogo instituta im. A.M. Gor'kogo [Bulletin of the Literary Institute named after A. M. Gorky]. Moscow, Iz-vo Literaturnogo instituta A.M. Gor'kogo Publ., 2012, no 1, pp. 15-21. (In Russian)

68 Grishchenko A.I. Ob ekspressivnosti etnonima zhidove v drevnerusskoi knizhnosti (na materiale Palei Tolkovoi) [About the expressiveness of the ethnonym zhudove in Old Russian literature (on the material of the Explanatory Paleia)] Slov'ians'kii zbirnik. Zb. nauk. prats' [Slavic collection. Collection of scientific works]. Odesa, Odes'kii natsional'nii un-t im. I.I. Mechnikova Publ., 2011, issues 14-15, pp. 94-102. (In Russian)

69 Grishchenko A.I. Slavianskie prikliucheniia grecheskogo Kegrata: O proiskhozhdenii nazvaniia drevnerusskoi “Knigi Kaaf” [Slavic adventures of Greek Kaguta: On the origin of the name of the ancient "Book of Kohath"]. Sloverne, 2012, vol. 1, no 2, pp. 95-100. (In Russian)

70 Gromov M.N. Filosofskoe znachenie "Tolkovoi Palei” [Philosophical significance of Explanatory Paleia]. "Paleia Tolkovaia» $v$ kontekste drevnerusskoi kul'tury XI-XVII vv. Materialy Pervoi mezhdunarodnoi nauchnoi konferentsii ["Paley Explanatory" in the context of old culture of the $11^{\text {th }}-17^{\text {th }}$ centuries. Materials of the First international scientific conference], ed. by A.N. Uzhankov. Moscow, Soglasie Publ., 2014, pp. 9-14. (In Russian)

71 Gromov M.N., Mil'kov V.V. Ideinye techeniia drevnerusskoi mysli [Ideological currents of Old Russian thought]. St. Petersburg, Izd-vo RKhGU Publ., 2001. 960 p. (In Russian)

72 Gudzii N.K. Istoriia drevnei russkoi literatury [History of Old Russian literature]. Moscow, Prosveshchenie Publ., 1966. 542 p. (In Russian)

73 Demin A.S. Drevnerusskaia literaturnaia animalistika [Old Russian literary animals]. Drevnerusskaia literatura: Izobrazhenie prirody i cheloveka [Old Russian literature: the Image of nature and human], ed. by A.S. Demin. Moscow, Nasledie Pudl., 1995, pp. 89-126. (In Russian)

74 Ermolenko S.M. Apokrificheskoe skazanie "O lestvitse, iuzhe vide Iakov" v sostave Tolkovoi Palei: sistema ritoricheskikh priemov, zhanrovye kharakteristiki [The Apocryphal legend "On the ladder that Jacob beheld" in Explanatory Paleia: system of rhetorical devices, genre characteristics]. Vestnik Novosibirskogo gosudarstvennogo universiteta. Seriia: istoriia, filologiia [Vestnik of Novosibirsk state University. Series: history, philology]. Novosibirsk, Novosibirskii gos. Universitet Publ., 2012. vol. 11, no 12, pp. 145-154. (In Russian)

75 Zhdanov I.N. Paleia [Paleia]. Sochineniia [Works]. St. Petersburg, 1904. Vol. 1. 871 p. (In Russian)

76 Zhdanov R.V. Kreshchenie Rusi i Nachal'naia letopis' [The baptism of Rus and the Primary chronicle]. Istoricheskie zapiski, 1939, no 5, pp. 3-30. (In Russian)

77 Zabolotskii P. K voprosu ob inozemnykh pis'mennykh istochnikakh "nachal'noi letopisi" [To the question about foreign written sources of the "Primary Chronicle"]. Russkii filologicheskii vestnik [Russian philological vestnik]. Varshava, 1901, vol. XLV, no 1-2, pp. 4-19. (In Russian) 
78 Zavadskaia S.V. Nabliudeniia nad terminologiei vetkhozavetnogo siuzheta o Moisee (po povodu sootnosheniia rannikh letopisnykh i paleinykh tekstov) [Observations on the terminology of the old Testament story about Moses (about the ratio of early chronicle and paleic texts)]. Vostochnaia Evropa $v$ drevnosti $i$ Srednevekov'e. Spornye problemy istorii. Chteniia pamiati V.T. Pashuto (Moskva, 12-14 apr. 1993 g.) [Eastern Europe in antiquity and the middle Ages. Controversial issues of history. Readings in memory of V.T. Pashuto (Moscow, 12-14 APR. 1993): Abstracts], ed. by A.P. Novosel'tsev. Moscow, In-t ros. Istorii Publ., 1993, pp. 28-31. (In Russian)

79 Istomin K.K. K voprosu o redaktsiiakh Tolkovoi palei [To the question of revisions of the Explanatory Paleia]. Izvestiia otdeleniia russkogo iazyka i slovesnosti, 1905, vol. 10, book 1, pp. 147-184. (In Russian)

80 Istomin K.K. K voprosu o redaktsiiakh Tolkovoi palei [To the question of revisions of the Explanatory Paleia]. Izvestiia otdeleniia russkogo iazyka i slovesnosti, 1906, vol. 11, book 1, pp. 337-374. (In Russian)

81 Istomin K.K. K voprosu o redaktsiiakh Tolkovoi palei palei [To the question of revisions of Explanatory Paleia]. Izvestiia otdeleniia russkogo iazyka i slovesnosti, 1909, vol. 13, book 4, pp. 290-343. (In Russian)

82 Istomin K.K. K voprosu o redaktsiiakh Tolkovoi palei palei [To the question of revisions of Explanatory Paleia]. Izvestiia otdeleniia russkogo iazyka i slovesnosti, 1913, vol. 18, book 1, pp. 87-172. (In Russian)

83 Istrin V.M. Vzaimootnoshenie polnoi i kratkoi Palei v predelakh teksta Palei Kolomenskoi. Obshchie vyvody. Tablitsy [The Relationship between full and brief Paley within the text Paley Kolomna. General conclusion. Table]. Izvestiia otdeleniia russkogo iazyka i slovesnosti, 1906, vol. 11, book 3, pp. 418-450. (In Russian)

84 Istrin V.M. Zamechaniia o sostave Tolkovoi Palei [Observations on the composition of Explanatory Paleia]. Izvestiia otdeleniia russkogo iazyka i slovesnosti, 1897, vol. 2, book 1, pp. 175-209. (In Russian)

85 Istrin V.M. Zamechanie o sostave Tolkovoi Palei. Glava IV: Kniga Kaaf Palei [Observations on the composition of Explanatory Paleia. Chapter 4: the Book Kohath]. Izvestiia otdeleniia russkogo iazyka i slovesnosti, 1897, vol 2, book 4, pp. 845-905. (In Russian)

86 Istrin V.M. Zamechaniia o sostave Tolkovoi Palei. Glavy V-XI: Zlataia Matitsa. Vizantiiskie prototipy Tolkovoi Palei [Observations on the composition of Explanatory Paleia. Chapters 5-11: Golden Matica. The Byzantine prototypes of Explanatory Paleia]. Izvestiia otdeleniia russkogo iazyka i slovesnosti, 1898, vol. 3, book 2, pp. 472-531. (In Russian)

87 Istrin V.M. Issledovaniia v oblasti drevnerusskoi literatury [Researches in the field of Old Russian literature]. St. Petersburg, Senat. tip. Publ., 1906. 257 p. (In Russian)

88 Istrin V.M. Osobyi vid Ellinskogo letopistsa iz sobraniia Tikhonravova [A special kind of Hellenic chronicler from the collection of Tikhonravov]. St. Petersburg, Tip. Imp. Akad. nauk Publ., 1912, pp. 3-27. (In Russian)

89 Istrin V.M. Redaktsii Tolkovoi Palei [The editions of Explanatory Paleia]. St. Petersburg, Tip. Imp. Akad. nauk Publ., 1907. 188 p. (In Russian) 
90 Istrin V.M. Redaktsii Tolkovoi Palei. Vzaimootnosheniia polnoi i kratkoi Palei v predelakh teksta Palei Kolomenskoi [The editions of Explanatory Paleia. The relationship of the long and the short Paley within the text Paley Kolomna]. Izvestiia otdeleniia russkogo iazyka i slovesnosti, 1906, vol. 11, book 1, pp. 1-43. (In Russian)

91 Istrin V.M. Redaktsii Tolkovoi Palei. Opisanie polnoi i kratkoi Palei [The editions of Explanatory Paleia. Description of the full and the short Paley]. Izvestiia otdeleniia russkogo iazyka i slovesnosti, 1905, vol. 10, book 4, pp. 135-203. (In Russian)

92 Istrin V.M. Tolkovaia Paleia i antievreiskaia literature [Explanatory Paleia and anti-Jewish literature]. Ocherk istorii drevnerusskoi literatury domoskovskogo perioda (11-13 vv.) [Essay on the history of Old Russian literature before Moscow period $\left(11^{\text {th }}-13^{\text {th }}\right.$ centuries $\left.)\right]$. Petrograd, Nauka i shkola Publ., 1922, pp. 213-224. (In Russian)

93 Istrin V.M. Tolkovaia Paleia i Khronika Georgiia Amartola [Explanatory Paleia and the Chronicle of George Hamartolos]. Izvestiia otdeleniia russkogo iazyka $i$ slovesnosti, 1924, vol. 29, pp. 369-379. (In Russian)

94 Istrin V.M. Khronika Georgiia Amartola v slaviano-russkom perevode i sviazannye s neiu pamiatniki [The chronicle of George Hamartolos in Slavic Russian translation and related monuments]. Zhurnal ministerstva narodnogo prosveshcheniia, 1917, no 59, May, pp. 1-35. (In Russian)

95 Istrin V.M. Khronograficheskaia chast' polnoi i kratkoi Palei i "Khronograf po velikomu izlozheniiu" [The chronographical part of the full and brief Paley and "The Chronograph for the great presentation"]. Izvestiia otdeleniia russkogo iazyka i slovesnosti, 1906, vol. 11, book 2, pp. 20-61. (In Russian)

96 Kagan M.D., Ponyrko N.V., Rozhdestvenskaia M.V. Opisanie sbornikov XV v. knigopistsa Efrosina [Description of the $15^{\text {th }}$ century's collections of the scribe Euphrosynus]. Trudu Otdela drevnerusskoi literatury [Researches of the Department of Old Russian literature]. Leningrad, Nauka Publ., 1980, vol. 35, p. 3-300. (In Russian)

97 Kagan-Tarkovskaia M.D. Legenda o d'iavole i Noevom kovchege po drevnerusskim rukopisnym sbornikam [The legend of the devil and Noah's ark on the Old Russian manuscript collections]. Issledovaniia po drevnei i novoi literature [Researches on old and new literature], ed. by L.A. Dmitriev. Leningrad, Nauka Publ., 1987, pp. 108-110. (In Russian)

98 Kamchatnov A.M. O semanticheskom slovare drevnerusskogo iazyka [About the semantic dictionary of Old Russian language]. Drevniaia Rus'. Voprosy medievistiki, 2000, no 1, pp. 61-65. (In Russian)

99 Kamchatnov A.M. Ob izdanii "Palei Tolkovoi" v istoricheskoi retrospektive i perspective [About the edition of Explanatory Paleia in historical retrospective and perspective]. "Paleia Tolkovaia" $v$ kontekste drevnerusskoi kul'tury XI-XVII vv. Materialy Pervoi mezhdunarodnoi nauchnoi konferentsii [Explanatory Paleia in the context of old culture of the $11^{\text {th }}-17^{\text {th }}$ centuries. Materials of the First international scientific conference], ed. by A.N. Uzhankov. Moscow, Soglasie Publ., 2014, pp. 231-237. (In Russian) 
100 Kamchatnov A.M. Orfografiia i tekstologiia (zametki na poliakh Tolkovoi Palei) [Spelling and textual criticism (field notes in Explanatory Paleia)]. Chestnomu $i$ groznomu Ivanu Vasilevichu. K 70-letiiu Ivana Vasilevicha Levochkina. Sbornik statei [To the honest and formidable Ivan Vasilievich. To the $70^{\text {th }}$ anniversary of Ivan Levochkin. Collection of articles]. Moscow, RFK-Imidzh Lab Publ., 2004, pp. 23-24. (In Russian)

101 Karneev A. K voprosu o vzaimootnosheniiakh Tolkovoi Palei i Zlatoi Matitsy [To the question about the relationship between Explanatory Paleia and Golden Matitsa]. Zhurnal ministerstva narodnogo prosveshcheniia, 1900, February, pp. 335-366. (In Russian)

102 Kozlova A.Iu. Vklad I.I. Sreznevskogo v issledovanie Tolkovoi Palei [Contribution of I.I. Sreznevsky to the study of Explanatory Paleia]. Dvesti let so dnia rozhdeniia akademika Izmaila Ivanovicha Sreznevskogo: sb. dokladov mezhdunarodnoi internet-konferentsii (Iaroslavl', 1-31 marta 2012 g.) [Two hundred years since the birth of Academician Izmail Ivanovich Sreznevsky: Sat. reports of the international Internet conference (Yaroslavl, March 1-31, 2012)], ed. by O.V. Lukin. Iaroslavl', Izd-vo IaGPU Publ., 2012, pp. 152-163. (In Russian)

103 Kozlova A.Iu. Zagadochnye slova "kliushche" i "kliuch" Tolkovoi Palei [The mysterious words "kliushche" and "kliuch" Explanatory Paleia]. Russkaia rech', 1994, no 3, pp. 75-80. (In Russian)

104 Kozlova A.Iu. K voprosu o lingvisticheskikh osobennostiakh starshikh spiskov "Tolkovoi Palei" [On the question of linguistic features of the older lists of Explanatory Paleia]. "Paleia Tolkovaia" v kontekste drevnerusskoi kul'tury XIXVII vv. Materialy Pervoi mezhdunarodnoi nauchnoi konferentsii [Explanatory Paleia in the context of old culture of the $11^{\text {th }}-17^{\text {th }}$ centuries, materials of the First international scientific conference], ed. by A.N. Uzhankov. Moscow, Soglasie Publ., 2014, pp. 189-224. (In Russian)

105 Kozlova A.Iu. K voprosu o lingvotekstologicheskikh osobennostiakh starshikh spiskov Tolkovoi Palei (RNB, SPbDA A. 1/119; RGADA, Sin. tip. № 53; RGB. Tr.-Serg. № 38) [To the question of linguotextology the features of the older lists of Explanatory Paleia (NLR, the Spbda A. 1/119; RGADA, SYN. type. No. 53; RSL. Tr.-Serg. No. 38)]. Mezhdunarodnaia filologicheskaia konferentsiia. SanktPeterburgskii universitet [International philological conference. St. Petersburg University]. St. Petersburg, 2013. Available at: http://www.conference-spbu.ru/ conference/13/ (Accessed 12 February 2019). (In Russian)

106 Kozlova A.Iu. K voprosu o sud'be odnogo iz sochinenii Aristotelia v knizhnosti Drevnei Rusi [To the question of the fate of one of Aristotle's works in the bookishness of Old Russia]. Iazyk i kul'tura. Tret'ia mezhdunarodnaia konferentsiia. Tezisy dokladov [Language and culture. Third international conference. Thesis of reports]. Kiev, Izd-vo zhurnala “Collegium” Publ., 1994, pp. 26-27. (In Russian)

107 Kozlova A.Iu.KolomenskiiskriptoriiXVv. (Kvoprosu o nekotorykhosobennostiakh iazyka i orfografii Kolomenskogo spiska Tolkovoi Palei) [Kolomensky scriptorium of the $15^{\text {th }}$ century (To the question about some of the peculiarities of language and orthography of the Kolomna list of Explanatory Paleia)]. Materialy dlia 
entsiklopedii "Kolomenskii krai" [Materials for the encyclopedia "Kolomenskiy region”]. Kolomna, KPI Publ., 1997, issues 3-4, pp. 13-19. (In Russian)

108 Kozlova A.Iu. Kolomenskii spisok Tolkovoi Palei kak leksikograficheskii istochnik [Kolomensky list of Explanatory Paleia as a lexicographic source]. Slovarnoe nasledie V.P. Zhukova i puti razvitiia russkoi i obshchei leksikografii [Dictionary heritage of V.P. Zhukov and ways of development of Russian and General lexicography]. Velikii Novgorod, NovGU Publ., 2004, pp. 396-398. (In Russian)

109 Kozlova A.Iu. Kolomenskii spisok Tolkovoi Palei 1406 g. kak lingvisticheskii istochnik [Kolomensky list of Explanatory Paleia of 1406 as a linguistic source: PhD thesis, summary]. Kolomna, 2007. (In Russian)

110 Kozlova A.Iu. Leksicheskie edinitsy, ispol'zuemye dlia oboznacheniia Vysshikh sil, v kolomenskom spiske Tolkovoi Palei 1406 goda [Lexical units used to refer to Higher powers in the Kolomna list of Explanatory Paleia of 1406]. Kolomna i Kolomenskaia zemlia: istoriia i kul'tura. Sbornik statei [Kolomna and Kolomna land: history and culture. Collection of articles], eds. by A.G. Mel'nik, S.V. Sazonov. Kolomna, Izd. dom “Liga” Publ, 2009, pp. 105-117. (In Russian)

111 Kozlova A.Iu. Leksicheskii sostav spiska Kolomenskogo spiska Tolkovoi Palei 1406 g. [Kolomna list's vocabulary of Explanatory Paleia of 1406]. Vladimir Dal' i sovremennaia filologiia: Materialy mezhdunarodnoi nauchnoi konferentsii 22-23 noiabria $2001 \mathrm{~g}$. [Vladimir Dahl and modern philology: Proceedings of the international scientific conference November 22-23, 2001]. Nizhnii Novgorod, NGLU im. N.A. Dobroliubova Publ., 2001, pp. 180-183. (In Russian)

112 Kozlova A.Iu. Neslavianskaia leksika v Kolomenskom spiske Tolkovoi Palei 1406 g. [Non-Slavic vocabulary in the Kolomna list of Explanatory Paleia of 1406]. Iazyk i mezhkul'turnaia kommunikatsiia. Materialy Vtoroi mezhdunarodnoi nauchnoprakticheskoi konferentsii. Velikii Novgorod, 19-20 maia 2011 [Language and intercultural communication. Materials of the Second international scientificpractical conference. Veliky Novgorod, 19-20 may 2011], ed. by O.A. Aleksandrova, E.F. Zhukova. Velikii Novgorod, NovGU Publ., 2011, pp. 77-85. (In Russian)

113 Kozlova A.Iu. O nekotorykh osobennostiakh peredachi "Shestodneva" Ioanna ekzarkha Bolgarskogo $\mathrm{v}$ raznykh spiskakh Palei Tolkovoi redaktsii [About some peculiarities of transmission "Hexaemeron" by John Bulgarian Exarch in different lists Explanatory Paleia's edition]. Russkoe slovo $v$ istoricheskom razvitii (XIV-XIX veka). Vyp. 4: Materialy sektsii «Istoricheskaia leksikologiia $i$ leksikografiia» XXXVII Mezhdunarodnoi filologicheskoi konferentsii. 11-15 marta $2008 \mathrm{~g}$. [Russian word in historical development $\left(14^{\text {th }}-19^{\text {th }}\right.$ centuries). Issue 4: Proceedings of the section "Historical lexicology and lexicography" $37^{\text {th }}$ International philological conference. 11-15 March 2008], eds. by S.Sv. Volkov, O.S. Mzhel'skaia. St. Petersburg, Nestor-Istoriia Publ., 2009, pp. 50-57. (In Russian)

114 Kozlova A.Iu. O nekotorykh osobennostiakh iazykovoi lichnosti redaktorasostavitelia Tolkovoi Palei [Some peculiarities of language personality of the editor-compiler of the Explanatory Paleia]. Aktual'nye voprosy izucheniia dukhovnoi kul'tury. Materialy Mezhdunarodnoi nauchno-prakticheskoi konferentsii "Slavianskaia kul'tura: istoki, traditsii, vzaimodeistvie. XII Kirillo-Mefodievskie 
chteniia" (17 maia 2011 g.) [Topical issues of the study of spiritual culture. Materials of the scientific and practical International conference "Slavic culture: origins, traditions, interaction. $12^{\text {th }}$ Cyril and Methodius readings" (may 17, 2011)]. Moscow, Iaroslavl', 2011. (In Russian)

115 Kozlova A.Iu. Osobennosti peredachi traktata Aristotelia "Historia animalium" v drevneishikh spiskakh Tolkovoi Palei [Features of transfer of Aristotle's treatise "Historia animalium" in the most old lists of Explanatory Paleia]. Mezhdunarodnaia kommunikatsiia v sovremennom mire. Materialy pervoi mezhdunarodnoi nauchnoi konferentsii [International communication in the modern world. Materials of the first international scientific conference].Tver', 2005, pp. 225-230. (In Russian)

116 Kozlova A.Iu. Otrazhenie kategorii odushevlennosti v Kolomenskom spiske Tolkovoi Palei $1406 \mathrm{~g}$. [Reflection of a category of animation in the Kolomna list of Explanatory Paleia of 1406]. Grammaticheskie kategorii i edinitsy: sintagmaticheskii aspekt. Materialy shestoi mezhdunarodnoi konferentsii [Grammatical categories and units: syntagmatic aspect. Proceedings of the sixth international conference]. Vladimir, VGPU Publ., 2005, pp. 83-86. (In Russian)

117 Kozlova A.Iu. Paleia Tolkovaia nachala XV veka iz Kolomny [Explanatory Paleia in beginning of the $15^{\text {th }}$ century from Kolomna]. Vestnik Kolomenskogo gosudarstvennogo pedagogicheskogo instituta, 2007, no 1 (12), pp. 21-32. (In Russian)

118 Kozlova A.Iu. Rol' lingvisticheskikh dannykh v issledovanii istorii teksta Tolkovoi Palei [The Role of linguistic data in the study of the history of the text of Explanatory Paleia]. Russkii iazyk: istoricheskie sud'by i sovremennost'. III Mezhdunarodnyi kongress issledovatelei russkogo iazyka (Moskva, MGU im. M.V. Lomonosova, filologicheskii fakul'tet, 20-23 marta $2007 \mathrm{~g}$ : Trudy i materialy [Russian language: its historical destiny and present state. $3^{\text {rd }}$ international Congress of Russian language researchers (Moscow, MSU M. V. Lomonosova, faculty of Philology, March 20-23, 2007: Proceedings and materials). Moscow, MAKS Press Publ., 2007, pp. 64-65. (In Russian)

119 Kozlova A.Iu. Svedeniia o 12-letnem vostochnom kalendare v "Tolkovoi Palee" [Information about the 12-year Eastern calendar in Explanatory Paleia]. Vspomogatel'nye istoricheskie distsipliny $v$ sovremennom nauchnom znanii. Materialy XXIX mezhdunarodnoi nauchnoi konferentsii. Moskva, 13-15 aprelia 2017 goda [Auxiliary historical disciplines in modern scientific knowledge. Proceedings of the $29^{\text {th }}$ international scientific conference. Moscow, April 13-15, 2017]. Moscow, IVI RAN Publ., 2017, pp. 183-185. (In Russian)

120 Kozlova A.Iu. Tolkovaia Paleia kak leksikologicheskii i leksikograficheskii istochnik [Explanatory Paleia as a lexicological and lexicographic source]. Aktual'nye problemy funktsional'noi leksikologii. Sb. statei, posviashch. 75-letiiu d-ra filolog. nauk, prof. V.V. Stepanovoi [Actual problems of functional lexicology. Collection of articles dedicated to the 75th anniversary of doctor of Philology, Professor V.V. Stepanova]. St. Petersburg, Izd-vo Sankt-Peterburgskogo un-ta ekonomiki i finansov Publ., 1997, pp. 53-56. (In Russian)

121 Kozlova A.Iu. Tolkovaia Paleia - entsiklopediia srednevekovogo cheloveka [Explanatory Paleia - encyclopedia of medieval man]. Apostol. Tserkovno- 
kul'turnyi zhurnal [Apostle. Church-cultural magazine]. Kolomna, Izdanie tserkvi apostola Ioanna Bogoslova Publ., 2009, no 1, pp. 14-15. (In Russian)

122 Kozlova A.Iu. "Trudnye" slova v tekstakh i slovariakh ["Difficult" words in texts and dictionaries]. Germenevtika drevnerusskoi literatury [Hermeneutics of Old Russian literature]. Moscow, Tip. "Neftianik”, 1994, issue 6, part II, ed. by V.M. Kirillin, pp. 342-357. (In Russian)

123 Kosmologicheskie proizvedeniia v knizhnosti Drevnei Rusi. Chast' II: Teksty ploskostno-komarnoi traditsii [Cosmological works in the literature of Old Russia. Part II: Texts of the plane-mosquito tradition], eds. by V.V. Mil'kov, S.M. Polianskii. St. Petersburg, Izd. dom “Mir” Publ., 2009. 623 p. (In Russian)

124 Kuznetsova V.S. Ustnoe bytovanie bibleiskoi legendy ob Iosife Prekrasnom: fol'klorizatsiia siuzheta [Oral existence of the biblical legend about Joseph the Beautiful: folklorization of the plot]. Sibirskii filologicheskii zhurnal, 2010, no 4, pp. 5-10. (In Russian)

125 Kuz'min A.G. Nachal'nye etapy drevnerusskogo letopisaniia [The Initial stages of the Old Russian chronicle]. Moscow, Nauka Publ., 1977. 394 p. (In Russian)

126 Kuskov V.V. Istoriia drevnerusskoi literatury [History of Old Russian literature]. Moscow, Vysshaia shkola Publ., 1989. 800 p. (In Russian)

127 Leonid, arkhimandrit. Bibliograficheskie razyskaniia $\mathrm{v}$ oblasti drevneishego perioda slavianskoi pis'mennosti IX-Xvv. [Bibliographical researches in the earliest period of Slavonic literature of the $9^{\text {th }}-10^{\text {th }}$ centuries]. Chteniia $v$ Imperatorskom obshchestve istorii i drevnostei Rossiiskikh pri Moskovskom universitete [Read in the Imperial society of history and Russian antiquities under the Moscow University], 1890, book 3, pp. 1-28. (In Russian)

128 Leonid, arkhimandrit. Chetyre besedy Kesariia, ili voprosy sviatogo Sil'vestra i otvety prepodobnogo Antoniia [The four discourses of Caesarea, or the questions of St. Sylvester and the answers of St. Anthony]. Obshchestvo liubitelei drevnei pis'mennosti [Society of lovers of old writing]. Moscow, 1890. Vol. 95. 20 p. (In Russian)

129 Letopisets Ellinskii i Rimskii. T. 2: Kommentarii $i$ issledovaniia [Chronicler of Hellenic and Roman. Vol. 2: Comments and research], ed. by O.V. Tvorogov. St. Petersburg, Dmitrii Bulanin Publ., 2001. 272 p. (In Russian)

130 Liban N.I. Literatura Drevnei Rusi: Lektsii-ocherki [Literature of Old Russia: Lectures-essays]. Moscow, Iz-vo MGU Publ., 2000. 112 p. (In Russian)

131 Likhachev D.S. Kommentarii k "Povesti vremennykh let" [Comments to "The Tale of bygone years"]. Povest' Vremennykh let [The Tale of Bygone years]. Moscow, Leningrad, Iz-vo AN SSSR Publ., 1950. Part 2. 556 p. (In Russian)

132 Likhachev D.S. Razvitie russkoi literatury X-XVII vekov. Epokhi i stili [Development of Russian literature of the $10^{\text {th }}-17^{\text {th }}$ centuries. Epochs and styles]. Leningrad, Nauka Publ., 1973. 254 p. (In Russian)

133 Lonchakova G.A. O kruge chteniia novgorodskogo pisatelia arkhiepiskopa Vasiliia Kaliki (XIV v.) [About reading of the writer of the Novgorod Archbishop Vasilii Kalika (14 ${ }^{\text {th }}$ century). Bibliosfera, 2007, no 4, pp. 60-70. (In Russian)

134 Lur'e Ia.S. Literaturnaia i kul'turno-prosvetitel'skaia deiatel'nost' Efrosina v 
kontse XV v. [Literary and cultural activities Euphrosynus in the end of the $15^{\text {th }}$ century]. Trudu Otdela drevnerusskoi literatury [Researches of the Department of Old Russian literature]. Moscow, Leningrad, Iz-vo AN SSSR Publ., 1961, vol. 17, pp. 130-168. (In Russian)

135 Lur'e Ia.S. Perevodnaia belletristika XIV-XV vv. [Translated fictionof the $14^{\text {th }}-$ $15^{\text {th }}$ centuries]. Istoki russkoi belletristiki [The Origins of Russian fiction], ed. by Ia.S. Lur'e. Leningrad, Nauka Publ., 1970, pp. 320-359. (In Russian)

136 L'vov A.S. Cheshsko-moravskaia leksika v pamiatnikakh drevnerusskoi pis'mennosti [Czech-Moravian vocabulary in the monuments of Old Russian writing]. Slavianskoe iazykoznanie. VI Mezhdunarodnoi s"ezd slavistov (Praga, avgust, 1968) [Slavonic linguistics. $6^{\text {th }}$ international Congress of Slavists (Prague, August 1968)]. Moscow, Nauka Publ., 1968, pp. 316-338. (In Russian)

137 Maksimovich K.A. Ptitsa Feniks v drevnerusskoi literature (k interpretatsii obraza) [Phoenix Bird in Old Russian literature (to the interpretation of the image)]. Germenevtika drevnerusskoi literatury [Hermeneutics of Old Russian literature]. Moscow, IWL RAS Publ., 1992, vol. 5, pp. 316-334. (In Russian)

138 Matveenko V.P., Shchegoleva L.N. Knigi vremennye i obraznye Georgiia Monakha [Books temporary and figurative by George Monk]. Moscow, Nauka Publ., 2006. Vol. 1, part 1.554 p. (In Russian)

139 Meskhina Sh.A., Tsintsadze Ia.Z. Iz istorii russko-gruzinskikh vzaimootnoshenii $X-X V I I I v v$. [From the history of Russian-Georgian relations of the $10^{\text {th }}-18^{\text {th }}$ centuries]. Tbilisi, Zaria Vostoka Publ., 1958, pp. 22-34. (In Russian)

140 Meshcherskii N.A. Istochniki i sostav drevnei slaviano-russkoi perevodnoi pis'mennosti IX-XV vekov [Sources and composition of the Old Slavonic-Russian translated writing of the $9^{\text {th }}-15^{\text {th }}$ centuries]. Leningrad, Izd-vo LGU Publ., 1978, 112 p. (In Russian)

141 Meshcherskii N.A. K voprosu ob izuchenii perevodnoi pis'mennosti Kievskogo perioda [About the study of translated writing of the Kiev period]. Izbrannye stat'i [Selected articles]. St. Petersburg, St. Peterburgskii universitet Publ., 1995, pp. 271-299. (In Russian)

142 Miltenov Ia. Dialozite na Psevdo-Kesarii v slavianskata r"kopisna traditsiia [Dialogues are Pseudo-Caesarea in the Slavic manuscript tradition]. Sofiia, Avalon Publ., 2006. 600 p. (In Bulgarian)

143 Miltenov Ia. Ekstserpite ot Dialozite na Psevdo-Kesarii v T"lkovnata Paleia [Excerpta Dialogues Pseudo-kesari in Explanatory Paleia]. Izvestiia na Nauchen tsent" $r$ "sv. Dazii Dorostolski" [Notification of the scientific center "St. Dasia Dorotysche"], 2007, no 2, pp. 183-196. (In Bulgarian)

144 Mil'kov V.V. Estestvennonauchnye svedeniia v "Tolkovoi Palee" i ikh istochniki [Natural-scientific data in Explanatory Paleia and its sources]. Drevniaia Rus'. Voprosy medievistiki, 2015, no 3 (61), pp. 85-86. (In Russian)

145 Mil'kov V.V. Kartina mira v Palee Tolkovoi [Picture of the world in Paley explanatory]. Vestnik slavianskikh kul'tur, 2016, no 3 (41), pp. 7-23. (In Russian)

146 Mil'kov V.V. Kosmologicheskie vozzreniia sostavitelia "Palei Tolkovoi" [Cosmological views of the compiler of Explanatory Paleia]. "Paleia Tolkovaia" 
$v$ kontekste drevnerusskoi kul'tury XI-XVII vv. Materialy Pervoi mezhdunarodnoi nauchnoi konferentsii [Explanatory Paleia in the context of Old Russian culture of the $11^{\text {th }}-17^{\text {th }}$ centuries. Materials of the First international scientific conference], ed. by A.N. Uzhankov. Moscow, Soglasie Publ., 2014, pp. 39-68. (In Russian)

147 Mil'kov V.V. Osobennosti transliatsii estestvennonauchnykh svedenii antichnogo proiskhozhdeniia v "Tolkovuiu Paleiu" [Features of the translation of natural science information of ancient origin in the "Explanatory Palea"]. Vspomogatel'nye istoricheskie distsipliny $v$ sovremennom nauchnom znanii. Materialy XXIX mezhdunarodnoi nauchnoi konferentsii. Moskva, 13-15 aprelia 2017 goda [Auxiliary historical disciplines in modern scientific knowledge. Proceedings of the $29^{\text {th }}$ international scientific conference. Moscow, April 13-15, 2017]. Moscow, IVI RAN Publ., 2017, pp. 237-239. (In Russian)

148 Mil'kov V.V. Paleinaia antropologiia i ee istochniki [Anthropology of Paley and its sources]. Istoriia filosofii [The history of philosophy]. Moscow, IFRAN Publ., 2014, no. 19, pp. 21-36. (In Russian)

149 Mil'kov V.V. Paleia Tolkovaia [Paley Explanatory]. Russkaia filosofiia. Entsiklopediia [Russian philosophy. Encyclopedia], ed. by M.A. Maslin. Moscow, Terra Knizhnyi klub "Knigovek” Publ., 2014, pp. 457-459. (In Russian)

150 Mil'kov V.V. Paleia Tolkovaia i ee religiozno-filosofskie osobennosti (O rasshirenii problemnogo polia pamiatnika v svete traditsii ego izucheniia) [Explanatory Paleia and its religious and philosophical features (on the expansion of the problem field of the monument in the light of the tradition of its study)]. Sud'ba Rossii $v$ sovremennoi istoriografi. Sbornik nauchnykh statei pamiati doktora istoricheskikh nauk, professora A.G. Kuz'mina [The fate of Russia in modern historiography. Collection of scientific articles in memory of doctor of historical sciences, professor A.G. Kuzmin], ed. by V.L. Matrosov. Moscow, Prometei Publ., 2006, pp. 490-501. (In Russian)

151 Mil'kov V.V. Religiozno-filosofskoe znachenie "Palei Tolkovoi" [Religious and philosophical meaning of Explanatory Paleia]. Filosofskie $i$ bogoslovskie idei $v$ pamiatnikakh drevnerusskoi mysli [Philosophical and theological ideas in the monuments of Old Russian thought], eds. by M.N. Gromov, V.V. Mil'kov. Moscow, Nauka Publ., 2000, pp. 108-113. (In Russian)

152 Miliutenko N.I. K voprosu o nekotorykh istochnikakh Rechi filosofa [To the question of some sources of the philosopher's Speech]. Trudu Otdela drevnerusskoi literatury [Researches of the Department of Old Russian literature]. St. Petersburg, Dmitrii Bulanin Publ., 2004, vol. 55, pp. 9-17. (In Russian)

153 Mikhailov A.V. K voprosu o proiskhozhdenii i literaturnykh istochnikakh Tolkovoi Palei [To the question of the origin and literary sources of Explanatory Paleia]. Izvestiia otdeleniia russkogo iazyka i slovesnosti, 1928, vol. 1, book 1, pp. 49-80. (In Russian)

154 Mikhailov A.V. K voprosu o tekste knigi Bytiia i proroka Moiseia v Tolkovoi Palee [To the question of the text of Genesis and the prophet Moses in Explanatory Paleia]. Varshavskie universitetskie izvestiia, 1895, no 9, pp. 1-35. (In Russian)

155 Mikhailov A.V. K voprosu o tekste knigi Bytiia i proroka Moiseia v Tolkovoi Palee 
[To the question of the text of Genesis and the prophet Moses in Explanatory Paleia]. Varshavskie universitetskie izvestiia, 1896, no 1, pp. 1-23. (In Russian)

156 Mikhailov A.V. Obshchii obzor sostava, redaktsii i literaturnykh istochnikov Tolkovoi Palei [General overview of the composition, editors and literary sources of Explanatory Paleia]. Varshavskie Universitetskie izvestiia, 1895, no. 7.21 p. (In Russian)

157 Mikhailov A.V. Opyt izucheniia teksta knigi Bytiia proroka Moiseia $v$ drevneslavianskom perevode. Ch. I: Parimeinyi tekst [Experience of studying the text of the book of Genesis of the prophet Moses in the old Slavic translation. Part I: Primary text]. Warsaw, Tipogr. Varshavskogo uchebn. okr. Publ., 1912. 824 p. (In Russian)

158 Mochul'skii V. Sledy narodnoi Biblii $v$ slavianskoi $i$ drevnerusskoi pis'mennosti [Traces of the national Bible in the Slavic and Old Russian writing]. Odessa, 1893. 285 p. (In Russian)

159 Nazarevskii O.A. K istorii russko-ukrainskikh literaturnykh sviazei [The history of Russian-Ukrainian literary relations]. Voprosy russkoi literatury. Mezhvedomstvennyi respublikanskii nauchnyi sbornik, izdannyi Chernovitskim gosudarstvennym universitetom [Problems of Russian literature. Interdepartmental Republican scientific collection published by Chernivtsi state University]. L'vov, Izd. L’vovskogo universiteta, 1967, issue 3 (6), pp. 16-20. (In Russian)

160 Nikol'skii N. O literaturnykh trudakh mitropolita Klimenta Smoliaticha, pisatelia XII veka [On the literary works of Metropolitan Kliment Smolyatich, writer of the $12^{\text {th }}$ century]. St. Petersburg, Tip. Imp. Akad. nauk Publ., 1892. 244 p. (In Russian)

161 Obolenskii M.A. O grecheskom kodekse Georgiia Amartola [About the Greek code of George Hamartolos]. Chteniia v Imperatorskom obshchestve istorii i drevnostei Rossiiskikh pri Moskovskom universitete [Read in the Imperial society of history and Russian antiquities under the Moscow University]. 1846, no 4, section 4, pp. 73-102. (In Russian)

162 Orlov A.A. "Potaennye knigi": iudeiskaia mistika v slavianskikh apokrifakh ["Secret books": Jewish mysticism in the Slavic Apocrypha]. Moscow Ierusalim, Gersharim Publ., 2011. 318 p. (In Russian)

163 Ostrovskii A. "Iosif Prekrasnyi": ot snovidtsa k mucheniku ["Joseph the Beautiful": from the dreamer to the Martyr]. Ot Bytiia $k$ Iskhodu. Otrazhenie bibleiskikh siuzhetov $v$ slavianskoi $i$ evreiskoi narodnoi kul'ture [From Genesis to Exodus. Reflection of biblical stories in Slavic and Jewish folk culture]. Moscow, GEOS Publ., 1998, pp. 181-192. (In Russian)

164 Paleia Tolkovaia po spisku, sdelannomu v Kolomne v 1406 g. Trud uchenikov N.S. Tikhonravova [Explanatory Paleia on the list made in Kolomna in 1406. Work of pupils of N.S. Tikhonravov]. Moscow, Tip. i slovolitnia O. Gerbska Publ., 18921896, issues 1-2. (In Russian)

165 Pamiatniki drevnerusskogo kanonicheskogo prava. Chast'. I: Pamiatniki XI-XV vv. [Monuments of Old Russian Canon law. Part 1: Monuments of the $11^{\text {th }}-15^{\text {th }}$ centuries], ed. by A.S. Pavlov. Russkaia istoricheskaia biblioteka [Russian historical library]. St. Petersburg, Pechatnia V.I. Golovina Publ., 1908. Vol. 6. 1472 p. (In Russian) 
166 Pamiatniki starinnoi russkoi literatury, izdavaemye grafom Grigoriem KushelevymBezborodko. Vyp. 3: Lozhnye $i$ otrechennye knigi russkoi stariny, sobrannye A.N. Pypinym [Monuments of Old Russian literature, published by count Grigory Kushelev-Bezborodko. Issue 3: False and abnegated books of Russian antiquity, collected by A.N. Pypin]. St. Petersburg, Tip. Kulisha Publ., 1862. 180 p. (In Russian)

167 Panaiotov V.B. Apokrif "Zavety dvenadtsati patriarkhov" v kontekste Tolkovoi Palei [The apocryphal "Testaments of the twelve patriarchs" in the context of Explanatory Paleia: PhD thesis, summary]. Moscow, 1986. (In Russian)

168 Panaiotov V.B. Za redaktsiite na T"lkovnata paleia [For behold of Explanaroty Paleia]. Episkop-Konstantinovi cheteniia [Bishop-Konstantinovi readings]. Shumen, 1996, vol. 2, pp. 256-260. (in Bulgarian)

169 Panaiotov V.B. Pronikvane na starob"lgarski pismeni pametnitsi v Kievska Rusiia [Penetration of old Bulgarian written monuments in Kiev Russia]. Die Slawischen Sprachen [The Slavic Languages], 1989, no 17, pp. 75-83. (In Bulgarian)

170 Peretts V.N. Issledovaniia i materialy po istorii starinnoi ukrainskoi literatury XVI$X V I I I v v$. [Researches and materials on the history of old Ukrainian literature of the $16^{\text {th }}-18^{\text {th }}$ centuries]. Leningrad, Izd-vo AN SSSR Publ., 1928. 255 p. (In Russian)

171 Piliavets L.B. "Zertsalo bogosloviia" Kirilla Trankviliota-Stavrovetskogo i "Paleia Tolkovaia" ["Mirror of theology" by Cyril Tranquilliot-Stavrovetsky and Explanatory Paleia]. Otechestvennaia obshchestvennaia mysl' epokhi Srednevekov'ia [Russian social thought of the middle ages]. Kiev, Naukova dumka Publ., 1988, pp. 245-250. (In Russian)

172 Piotrovskaia E.K. Drevnerusskaia versiia "Khristianskoi Topografii" Koz'my Indikoplova i "Tolkovaia Paleia" [Old Russian version of the "Christian topography" of Cosmas Indikoplov and Explanatory Paleia]. Trudu Otdela drevnerusskoi literatury [Researches of the Department of Old Russian literature]. St. Petersburg, Dmitrii Bulanin Publ., 1993, vol. 48, pp. 138-142. (In Russian)

173 Podskal'ski G. Khristianstvo i bogoslovskaia literatura Kievskoi Rusi (988-1237 gg.) [Christian and theological literature of Kievan Rus (988-1237)], transl. by A.V. Nazarenko. St. Petersburg, Vizantinorossika Publ., 1996, vol. 1. 572 p. (In Russian)

174 Popov A.N. Kniga Bytiia nebesi i zemli (Paleia istoricheskaia). S prilozheniem sokrashchennoi palei russkoi redaktsii [The book of Genesis of heaven and earth (Paley historical). With the Appendix of the abridged Paley of the Russian edition]. Moscow, Obshchestvo istorii i drevnostei ros. pri Mosk. un-te Publ., 1881. 320 p. (In Russian)

175 Popov G.V. Miniatiury Pskovskoi Palei 1477 g. (o nekotorykh aspektakh razvitiia rukopisnoi illiustratsii groznenskogo vremeni) [Miniatures of the Pskov Palei in 1477 (on some aspects of the development of manuscript illustration Grozny time)]. Drevnerusskoe iskusstvo: issledovaniia $i$ attributsiia [Old Russian art: researches and attribution]. St. Petersburg, Dmitrii Bulanin Publ., 1997, pp. 325-341. (In Russian)

176 Porfir'ev I.Ia. Apokrificheskie skazaniia o vetkhozavetnykh litsakh $i$ sobytiiakh 
[Apocryphal tales of the old Testament persons and events]. Kazan', Univ. tip. Publ., 1872. 309 p. (In Russian)

177 Porfir'ev I.Ia. Apokrificheskie skazaniia o vetkhozavetnykh litsakh i sobytiiakh po rukopisiam Solovetskoi biblioteki [Apocryphal tales of the old Testament persons and events from the manuscripts of the Solovetsky library]. Sbornik otdeleniia russkogo iazyka i slovesnosti [Collection of the Department of Russian language and literature]. St. Petersburg, 1877. Vol. 17, no 1.276 p. (In Russian)

178 Protas'eva T.N. Pskovskaia Paleia 1477 g. [Pskov Paley 1477]. Drevnerusskoe iskusstvo: Khudozhestvennaia kul'tura Pskova [Old Russian art: Art culture of Pskov], eds. by V.N. Lazarev, O.I. Podobedova, V.V. Kostochkin. Moscow, Nauka Publ., 1968, pp. 97-108. (In Russian)

179 Purynycheva G.M. Sushchnost' $i$ istoki russkoi dukhovnosti (sotsial'no-filosofskii analiz) [The nature and origins of Russian spirituality (the socially-philosophical analysis): PhD thesis, summary]. Moscow, 1999. 35 p. (In Russian)

180 Redin E. Tolkovaia litsevaia Paleia XVI-go veka sobraniia gr. A.S. Uvarova [Explanatory facial Paley of the $16^{\text {th }}$ century from the collection of A.S. Uvarov]. Pamiatniki drevnei pis'mennosti $i$ iskusstva. Otchety o zasedaniiakh Imperatorskogo obshchestva liubitelei drevnei pis'mennosti v 1900-1901 godu s prilozheniiami [Monuments of old writing and art. Records of the meetings of the Imperial society of lovers of old writing in 1900-1901 with annexes]. St. Petersburg, Tip. I.N. Skorokhodova Publ., 1901, vol. 141, pp. 1-9. (In Russian)

181 Robinson A.N. Literatura Drevnei Rusi v literaturnom protsesse Srednevekov'ia XI$X V I I I v v$. [Literature of Old Russia in the literary process of the Middle Ages of the $11^{\text {th }}-18^{\text {th }}$ centuries]. Moscow, Nauka Publ., 1980. 336 p. (In Russian)

182 Rozhdestvenskaia M.V. Bibleiskie apokrify v literature i knizhnosti Drevnei Rusi: istorikoliteraturnoe issledovanie [Biblical Apocrypha in literature of Old Russia: historical and literary research: $\mathrm{PhD}$ thesis, summary]. St. Petersburg, 2004. 79 p. (In Russian)

183 Russkii vestnik, 1892, no 1.432 p. (In Russian)

184 Rystenko A.V. Materialy dlia literaturnoi istorii Tolkovoi Palei [Materials for the literary history of Explanatory Paleia]. Izvestiia otdeleniia russkogo iazyka $i$ slovesnosti, 1908, vol. 13, part 2, pp. 324-334. (In Russian)

185 Svodnyi katalog slaviano-russkikh rukopisnykh knig, khraniashchikhsia v SSSR. XIXIII v. [Summary catalogue of Slavonic-Russian handwritten books stored in the USSR. $11^{\text {th }}-13^{\text {th }}$ centuries], ed. by L.P. Zhukovskaia. Moscow, Nauka Publ., 1984. 405 p. (In Russian)

186 Sergeev V.N. Ob odnoi osobennosti v ikonografii vetkhozavetnoi "Troitsy" [About one feature in the iconography of the old Testament "Trinity"]. Drevnerusskoe iskusstvo $X V-X V I I$ vekov [Old Russian art of the $15^{\text {th }}-17^{\text {th }}$ centuries], ed. by V.N. Sergeev. Moscow, Iskusstvo Publ., 1981, pp. 26-31. (In Russian)

187 Slavova T. Niakoi srednovekovyi predstavi za choveshkata fiziologiia i embriologiia [Some medieval ideas about human physiology and embryology]. Eslovistica Computense, 2002, no 2, pp. 243-251. (In Bulgarian)

188 Slavova T. T'lkovnata paleia v konteksta na starob"lgarskata knizhnina [Explanatory Paleia in the context of Old Bulgarian literature]. Sofiia, Universitetsko Izd-vo 
“Sv. Kliment Okhridski” Publ., 2002. 577 p. (in Bulgarian)

189 Slovar' knizhnikovi knizhnosti Drevnei Rusi [The dictionary of scribes and booklore of Old Russia]. St. Petersburg, Nauka Publ., 1989. Issue 2: Vtoraia polovina XIVXVI v. [the second half of the $14^{\text {th }}-16^{\text {th }}$ centuries], part $2.528 \mathrm{p}$. (In Russian)

190 Smirnov A.A. Zavety dvenadtsati patriarkhov, synovei Iakova [Covenants of the twelve patriarchs, sons of Jacob]. Kazan', Tipolitogr. Imp. un-ta Publ., 1911. 301 p. (In Russian)

191 Smirnov I. Opisanie rukopisnykh sbornikov Novgorodskoi Sofiiskoi biblioteki [Description of the manuscript collections of the Novgorod Sofia library]. Letopis' zaniatii Arkheograficheskoi komissii [Chronicle of the archaeological Commission]. St. Petersburg, 1864, issue 3, section 3. 106 p. (In Russian)

192 Sobolevskii A.I. Neskol'ko slov o litsevykh rukopisiakh [A few words about illuminated manuscripts]. Izvestiia otdeleniia russkogo iazyka i slovesnosti, 1908, vol. 13, book 1, pp. 95-96. (In Russian)

193 Sreznevskii I.I. Skazanie o sviatykh Borise i Glebe: Sil'vestorovskii spisok XIV v. [The Legend of saints Boris and Gleb: Sylvester's list of the $14^{\text {th }}$ century]. St. Petersburg, Tip. Imp. Akad. nauk Publ., 1860. 147 p. (In Russian)

194 Sreznevskii I.I. Slovar' drevnerusskogo iazyka [Dictionary of the Old Russian language]. Moscow, Kniga Publ., 1989, vol. 2, part 2. 854-1802 col. (In Russian)

195 Stankov R.A. Drevnerusskaia knizhnaia i narodnaia leksika v iazyke Istoricheskoi Palei [Old Russian book and folk vocabulary in the language of Historical Paley: PhD thesis, summary]. Moscow, 1985. 25 p. (In Russian)

196 Stankov R.A. Istoricheskaia Paleia - pamiatnik bolgarskoi kul'tury [Historical Paley as a monument of Bulgarian culture]. Palaeobulgarica - Starob"lgaristika, 1986, no 4, pp. 55-63. (In Russian)

197 Stroev P. Khronologicheskoe ukazanie materialov otechestvennoi istorii, literatury, pravovedeniia do nachala XVIII stoletiia [Chronological indication of materials of national history, literature, law to the beginning of the $18^{\text {th }}$ century]. Zhurnal ministerstva narodnogo prosveshcheniia, 1834. Part 2. 37 p. (In Russian)

198 Sukhomlinov M.I. O drevnei russkoi letopisi, kak pamiatnike literaturnom [On the Old Russian chronicle as a literary monument]. St. Petersburg, V tip. Imp. Akad. nauk Publ., 1856. 269 p. (In Russian)

199 Tvorogov O.V. Drevnerusskie khronografy [The Old Russian chronographs], ed. by Ia.S. Lur'e. Leningrad, Nauka. Leningradskoe otdelenie Publ., 1975. 320 p. (In Russian)

200 Tvorogov O.V. K rannim russko-evreiskim literaturno-tekstovym sviaziam (XIXVI vv.) [To the early Russian-Jewish literary and textual relations $\left(11^{\text {th }}-16^{\text {th }}\right.$ centuries)]. Slaviane $i$ ikh sosedi [Slavs and their neighbors]. Moscow, Nauka Publ., 1993, pp. 46-54. (In Russian)

201 Tvorogov O.V. Letopis' - Khronika - Paleia (vzaimootnoshenie pamiatnikov i metodika ikh issledovaniia) [Annals - Chronicle - Paley (relationship of monuments and methods of their research)]. Armianskaia i russkaia srednevekovaia literatury [Armenian and Russian medieval literature], ed. by D.S. Likhachev. Erevan, Izd-vo AN ArmSSR Publ., 1986, pp. 19-30. (In Russian) 
202 Tikhonravov N.S. Istoriia rossiiskoi slovesnosti drevnei i novoi. Sochinenie A. Galakhova (rets.) [The old and new History of Russian literature. The work of A. Galakhov (ed.)]. Otchet o deviatnadtsatom prisuzhdenii nagrad gr. Uvarova. 25 sentiabria $1876 \mathrm{~g}$. [Report on the nineteenth award of gr. Uvarov. September 25, 1876]. St. Petersburg, V tip. Imp. Akad. nauk Publ., 1878. 124 p. (In Russian)

203 Tikhonravov N.S. Pamiatniki otrechennoi literatury [Monuments of renounced literature]. Moscow, V tip. tov-va "Obshchestvennaia pol'za” Publ., 1863. Vol. 1. 313 p. (In Russian)

204 Tikhonravov N.S. Sochineniia: $v 3 t$. [Works: in 3 vols.]. St. Petersburg, Izd-e M. i S. Sabashnikovykh Publ., 1894. Vol. 1. 583 p. (In Russian)

205 Tolkovaia paleia $1477 \mathrm{~g}$. Vosproizvedenie Sinodal'noi rukopisi № 210 [Explanatory Paleia of 1477. Reproduction of the Synodal manuscript no. 210]. Obshchestvo liubitelei drevnei pis'mennosti [The society of lovers of old literature]. St. Petersburg, 1892, vol. 93, issue 1.302 p. (In Russian)

206 Toporov V.N. Sviatost' i sviatye v russkoi dukhovnoi kul'ture. T. 1: Pervyi vek khristianstva na Rusi [Holiness and saints in Russian spiritual culture. Vol. 1: the First century of Christianity in Russia]. Moscow, Iazyki russkoi kul'tury Publ., 1995. 873 p. (In Russian)

207 Uzhankov A.N. Kniga neba i zemli [Book of heaven and earth]. "Paleia Tolkovaia" $v$ kontekste drevnerusskoi kul'tury XI-XVII vv. [Explanatory Paleia in the context of the old culture of the $11^{\text {th }}-17^{\text {th }}$ centuries]. Moscow, Soglasie Publ., 2014, pp. 7-8. (In Russian)

208 Uspenskii B.A. Filologicheskie nabliudeniia nad tekstom "Otkroveniia Avraama" [Philological observations on the text of "Revelation of Abraham"]. Voprosy iazykoznaniia, 2015, no 5, pp. 49-86. (In Russian)

209 Uspenskii V. Tolkovaia Paleia [Explanatory Paleia]. Kazan', Tip. Imp. un-ta Publ., 1876. 134 p. (In Russian)

210 Khazanova S.I. Apokrify o Moisee v drevnerusskoi pis'mennosti [Apocrypha about Moses in Old Russian writing]. Rus', Rossiia. Srednevekov' i Novoe vremia, 2013, no 3, pp. 128-136. (In Russian)

211 Khazanova S.I. Otryvok iz "Otkroveniia Avraama” v Palee Tolkovoi s otdel'nymi vstavkami, vstrechaiushchimisia v Khronograficheskoi Palee sobraniia Undol'skogo [Excerpt from “The Revelation of Abraham” in Explanatory Paleia with separate inserts, occurring in the Chronographic Palea of The Undolsky collection]. Vspomogatel'nye istoricheskie distsipliny $v$ sovremennom nauchnom znanii. Materialy XXIX mezhdunarodnoi nauchnoi konferentsii. Moskva, 13-15 aprelia 2017 goda [Auxiliary historical disciplines in modern scientific knowledge. Proceedings of the $29^{\text {th }}$ international scientific conference. Moscow, April 13-15, 2017]. Moscow, IVI RAN Publ., 2017, pp. 320-322. (In Russian)

212 Chernaia L.A. Vzgliad na chelovecheskuiu prirodu v drevnerusskoi literature [View on human nature in the Old Russian literature Drevnerusskaia literature]. Drevnerusskaia literatura: Izobrazhenie prirody i cheloveka [Old Russian literature: the Image of nature and man], ed. by A.S. Demin. Moscow, Spetsializir. izd.torgovoe predpriiatie "Nasledie" Publ., 1995, pp. 127-157. (In Russian) 
213 Cholova Ts. Estestveno-nauchnite znaniia v srednovekovna B"lgariia [Naturalscientific knowledge in medieval Bulgaria]. Sofia, Izd-vo na B"lg. akad. Naukite Publ., 1988. 401 p. (In Bulgarian)

214 Shakhmatov A.A. Povest' vremennykh let i ee istochniki [The Tale of temporary years and its sources]. Trudu Otdela drevnerusskoi literatury [Researches of the Department of Old Russian literature]. Moscow, Leningrad, Izd-vo AN SSSR Publ., 1940, vol. 4, pp. 9-150. (In Russian)

215 Shakhmatov A.A. Tolkovaia Paleia i russkaia letopis' [Explanatory Paleia and Russian chronicle]. Stat'i po slavianovedeniiu [Articles on Slavonic]. St. Petersburg, 1904, issue 1, pp. 199-272. (In Russian)

216 Shcheglov A.P. Drevnerusskaia noumenal'naia naturfilosofiia [Old Russian noumenal natural philosophy]. Moscow, Ierusalim, 1999. 200 p. (In Russian)

217 Shcheglov A.P. Religiozno-filosofskoe soderzhanie Tolkovoi Palei [Religious and philosophical content of Explanatory Paleia]. Zhurnal Istoriko-bogoslovskogo obshchestva [Journal of Historical and theological society]. Moscow, 1991, issue 2, p. 7. (In Russian)

218 Shcheglov A.P. Filosofskoe soderzhanie "Tolkovoi Palei" po materialam russkikh rukopisei [Philosophical content of "Sensible Palea" based on the materials of Russian manuscripts: PhD thesis, summary]. Moscow, 1994. 18 p. (In Russian)

219 Iaroshenko-Titova L.V. "Povest' ob uvoze Solomonovoi zheny" v russkoi letopisnoi traditsii XVII-XVIII vv. ["The Tale of Solomon's wife's abduction” in the Russian chronicle tradition of the $17^{\text {th }}-18^{\text {th }}$ centuries]. Trudu Otdela drevnerusskoi literatury [Researches of the Department of Old Russian literature]. Leningrad, Nauka Publ., 1974, vol. 29, pp. 257-273. (In Russian)

220 Louria J. Une legende inconnue de Solomon et Kitovras dans un manuscrit du XV siècle. Revue des Etudes Slaves, 1964, vol. 43, pp. 7-11. (In French)

221 Michajlov A. Zur Entstehungsgeschichte der "Tolkovaja Paleja”. Zeitschrift für Slavische Philologie, 1927, Bd. 4. S. 115-131. (In German)

222 Philonenko-Sayar B., Philonenko M. L’Apocalypse d'Abraham. Introduction, texte slave, traduction et notes. Semitica. Paris, 1981, no 341, pp. 37-105. (In French)

223 Rubinkiewicz R. L'Apocalypse d'Abraham. Introduction, texte critique, traduction et commentaire. Lublin, Towarzystwo Naukowe Katolickiego Uniwersytetu Lubelskiego, 1987. (In French)

224 Taube M. The Slavic Life of Moses and Hebrew Sources. Jews and Slavs. St. Petersburg; Jerusalem, 1993, vol. 1, pp. 93-114. (In English)

225 Thomson F.J. The Slavonic Translation of the Old Testament. Interpretation of the Bible. Ljubljana; Sheffield, 1998. (In English)

226 Trunte N. Paleja Tolkovaja. Zeitschrift für Slavische Philologie. 2003. Bd. 62. S. 440-445. (In German)

227 Turdeanu E. La Chronique de Moïse en russe. Revue des Etudes Slaves, 1967, vol. 46, pp. 35-64. (In French)

228 Available at: http://www.mamif.org.paleja.htm (Accessed 12 February 2019). 


\section{O6 aвmope / about author}

Владимир Владимирович Мильков - доктор философских наук, ведущий научный сотрудник, Федеральное государственное бюджетное учреждение науки Институт философии, Российская академия наук, ул. Гончарная, д. 12, стр. 1, 109240 г. Москва, Россия.

E-mail:dr_milkov@mail.ru

Vladimir V. Milkov - DSc in Philosophy, Leading Researcher, Federal State Department Research Institution Institute of Philosophy of the Russian Academy of Sciences, Goncharnaia St. 12/1, 109240 Moscow, Russia.

E-mail:dr_milkov@mail.ru 